UNIVERSIDADE DE SÃO PAULO

ESCOLA DE ENGENHARIA DE LORENA

LUANDA MARIA ABREU SILVA DE CAMPOS

Estudo dos parâmetros fermentativos na obtenção de aguardente de mel

Lorena - SP 



\title{
Estudo dos parâmetros fermentativos na obtenção de aguardente de mel
}

\begin{abstract}
Tese apresentada à Escola de Engenharia de Lorena da Universidade de São Paulo para obtenção do título de Doutor em Ciências do Programa de Pós-graduação em Biotecnologia Industrial na área de concentração Microbiologia Aplicada
\end{abstract}

Orientador: Dr. Ismael Maciel de Mancilha

Edição reimpressa e corrigida

\section{Lorena}

Novembro, 2011 
Catalogação na Publicação

Biblioteca "Cel. Luiz Sylvio Teixeira Leite"

Escola de Engenharia de Lorena da Universidade de São Paulo

Campos, Luanda Maria Abreu Silva de

Estudo dos parâmetros fermentativos na obtenção de aguardente de mel. / Luanda Maria Abreu Silva de Campos. - ed. reimpr., corr. - 2011.

167 p. : il.

Tese (Doutor em Ciências - Programa de Pós-Graduação em Biotecnologia Industrial na Área de Microbiologia Aplicada) - Escola de Engenharia de Lorena da Universidade de São Paulo. 2011.

Orientador: Ismael Maciel de Mancilha

1. Aguardente de mel 2. Fermentação alcoólica 3. Leveduras. I. Título

$663.14-\mathrm{CDU}$ 
Dedico esta tese a meu esposo Mário e meus filhos Artur e Davi pela paciência, amor e compreensão durante estes anos. Meus meninos, amo vocês! 



\section{AGRADECIMENTOS}

À Deus e Nossa Senhora Aparecida, pela força e proteção durante esta caminhada.

Ao meu marido, companheiro e amigo Mário, pelo apoio, incentivo e compreensão durante esses anos.

Aos meus filhos amados Artur e Davi, por alegrarem meus dias e me fazerem a mulher mais feliz do mundo.

Aos meus pais Lemos e Dora, pelo exemplo de vida, amor e apoio sempre. Aos meus irmãos pela amizade e companherismo.

À minha querida sogra Dulcinéa, pelo carinho e ajuda com as crianças sempre que precisei.

Ao Prof. Dr. Ismael Maciel de Mancilha, pela valiosa orientação, paciência, oportunidade e pela confiança em meu trabalho.

Aos amigos de laboratório Juan, Tatiane, Wagner, Diego, Cláudio e em especial Adrieli e Flávio, pela amizade, auxílio e horas de trabalho compartilhadas.

Aos professores, funcionários e servidores que de alguma maneira contribuiram para a realização desta tese.

À Associação Rural de Canas, que gentilmente cedeu os alambiques para a produção da aguardente de mel.

À empresa Biorigin, pelo fornecimento do extrato de levedura comercial.

À Prof ${ }^{a}$ Dra. Helena Maria André Bolini pelo auxílio durante a análise sensorial.

À CAPES e FAPESP, pelo apoio financeiro. 



\section{BIOGRAFIA}

Luanda Maria Abreu Silva de Campos, nasceu em 5 de julho de 1978, em Volta Redonda/RJ, onde viveu até 1988.

Em 1997 ingressou no curso de Engenharia de Alimentos da Universidade Federal de Santa Catarina-UFSC, Florianópolis/SC. Neste período, durante 2 anos, desenvolveu atividades em nível de iniciação científica no Laboratório de Extração Supercrítica da mesma universidade, focando suas pesquisas na aplicação desta técnica na extração de produtos naturais. Em 2002 iniciou seus estudos de pós-graduação, em nível de mestrado, no mesmo laboratório dando continuidade à sua pesquisa e obtendo o título de mestre em Engenharia de Alimentos em 2004. Após o mestrado, teve a oportunidade de trabalhar como pesquisadora no Centro de Biotecnologia da Amazônia - Manaus/AM, durante 1 ano.

Em 2007, deu continuidade aos estudos de pós-graduação, em nível de doutorado, ingressando no programa de Pós-graduação em Biotecnologia Industrial do Departamento de Biotecnologia da Escola de Engenharia de Lorena - EEL/USP. Neste, focou seus estudos na área de Microbiologia Industrial e Fermentações, estudando os parâmetros fermentativos envolvidos no processo de produção de aguardente de mel. 



\section{RESUMO}

CAMPOS, L. M. A. S. Estudo dos Parâmetros Fermentativos na Obtenção de Aguardente de Mel. 2011. 167 p. Tese (Doutorado em Ciências ). Escola de Engenharia de Lorena, Universidade de São Paulo, Lorena, São Paulo. 2011.

No presente trabalho, primeiramente avaliou-se o desempenho fermentativo de 10 cepas de leveduras isoladas de frutas, de mel centrifugado e de resíduo do processamento de mel após a etapa de sedimentação (borra do mel), em tubo de ensaio contendo mosto constituído de Mel $15{ }^{\circ}$ Brix suplementado, individualmente, com diferentes nutrientes, a saber: extrato de levedura comercial $(10,0 \mathrm{~g} / \mathrm{L})$, farelo de arroz $(20,0 \mathrm{~g} / \mathrm{L})$, mistura $(1,0$ g/L) constituída de farelos de milho, arroz e soja na proporção 5:2:5 e nutriente comercial (D\&R) $(0,15 \mathrm{~g} / \mathrm{L})$. Os parâmetros avaliados coexistiram da determinação do número de células em câmara de Neubauer e das concentrações de açúcares e etanol por HPLC, o que permitiu a determinação dos parâmetros rendimento, eficiência de fermentação e produtividade. Estes resultados sustentaram a seleção do mosto suplementado com extrato de levedura comercial e da melhor cepa de levedura que foram posteriormente avaliados em escala piloto. A cepa selecionada foi a levedura isolada a partir da borra de mel, a qual foi posteriormente identificada como Saccharomyces cerevisiae e nomeada Saccharomyces cerevisiae EEL 2009. A avaliação da produção de aguardente de mel em escala piloto foi realizada nas instalações do Alambique da Associação Rural de Canas, Canas-SP e o destilado obtido armazenado em tonel de carvalho de 200 L por 6 meses. Amostras foram coletadas a cada 30 dias para caracterização físico-química em conformidade com os parâmetros estabelecidos na Legislação Brasileira para aguardente de frutas. Em paralelo, as respectivas amostras foram devidamente avaliadas sensorialmente por 120 provadores não treinados, por meio de testes de aceitação, em escala hedônica, considerando os quesitos aparência, aroma, sabor, corpo e impressão global, além da atitude de compra. Estes resultados foram analisados estatisticamente por ANOVA e teste de Tukey, sendo os resultados de aceitação em relação à impressão global, analisados por meio da análise multivariada o que permitiu traçar o Mapa de Preferência Interno - MDPREF. Os resultados referentes à caracterização físico-química das respectivas amostras demonstraram que todas apresentaram os parâmetros de avaliação em conformidade com os padrões estabelecidos pela legislação. Os resultados da análise sensorial revelaram que o tempo de armazenamento de 180 dias em tonel de carvalho não foi suficiente para a 
ocorrência de reações desejadas, o que influenciaria nas características sensoriais da bebida, tornado-a mais agradável e suave. No entanto, apesar do pouco tempo de armazenamento, a aguardente de mel apresentou uma boa aceitação por parte dos provadores, cuja maioria manifestou sua aceitação em termos de "gostei ligeiramente" e “não gostei, nem desgostei”. No tocante ao MDPREF, este revelou que a amostra referente a 180 dias de armazenamento foi preferida por um maior número de provadores. Em relação à atitude de compra, as amostras armazenadas por $60 \quad(79,17 \%)$ e 180 dias $(75,83 \%)$ apresentaram os melhores resultados. Diante do exposto, conclui-se que o mel se apresenta como uma alternativa viável para a formulação de mosto para produção de aguardente no período de entre safra de cana-de-açúcar, contribuindo para melhor aproveitamento das instalações e como fonte alternativa de renda para o produtor rural.

Palavras-chave: Aguardente de mel. Fermentação alcoólica. Leveduras. 


\begin{abstract}
CAMPOS, L. M. A. S. Study of the fermentative parameters in the process of obtaining honey spirit. 2011. 167 p. Thesis (Doctor of Science ). Escola de Engenharia de Lorena, Universidade de São Paulo, Lorena, São Paulo. 2011.
\end{abstract}

In this work, first it was evaluated the fermentation performance of 10 yeast strains isolated from fruits, centrifuged honey and residue of honey processing after the sedimentation (sludge honey) step. This experiment was carried out in test tube containing wort made from honey $15{ }^{\circ}$ Brix supplemented individually with different nutrients, namely: commercial yeast extract $(10.0 \mathrm{~g} / \mathrm{L})$, rice bran $(20.0 \mathrm{~g} / \mathrm{L})$, mixture $(1.0 \mathrm{~g} / \mathrm{L})$ consisting of bran corn, rice and soy in the ratio 5:2:5 and commercial nutrient (D\&R) $(0.15 \mathrm{~g} / \mathrm{L})$. The parameters evaluated included the cell number determination in Neubauer chamber, and sugars and ethanol concentrations by HPLC, which allowed to determine the fermentation parameters as yield, fermentation efficiency and productivity. These results supported the selection of the wort supplemented with commercial yeast extract and the best yeast strain, which were subsequently evaluated in a pilot scale. The selected strain was the yeast isolated from the sludge honey, which was later identified as Saccharomyces cerevisiae and named Saccharomyces cerevisiae EEL 2009. The production evaluation of honey spirit on a pilot scale was conducted at the Canas Rural Association Pilot Plant for cachaça production - Canas-SP and distillate was stored in oak barrel of 200 liters per 6 months. Samples were collected every 30 days for physic-chemical characterization in accordance with the guidelines established in the Brazilian Legislation for fruit spirit. Beyond that, the respective samples were properly sensory evaluated by 120 untrained consumers regarding to acceptance testing employing a hedonic scale, considering characteristics as appearance, aroma, flavor, and overall impression, and the attitude of purchase, as well. These results were statistically analyzes by ANOVA and Tukey`s test and the results of acceptance regarding to the overall impression, were analyzed by multivariate analysis which allowed tracing the Internal Preference Map - MDPREF. The results concerning the physic-chemical characterization of the respective samples showed that all presented the evaluation parameters in accordance with standards established by the legislation. The results of sensory analysis revealed that the storage time of 180 days in oak barrel was not enough for the occurrence of desired reactions, which influence the sensory characteristics of the beverage, making it nicer and smoother. However, despite short time 
storage, honey spirit showed good acceptance by the consumers. Most of them expressed acceptance in terms of "liked slightly" and "not liked nor disliked". Regarding the MDPREF results, these proved that the sample relating to 180 days of storage was preferred by majority of consumers. Regarding the attitude of purchase, the samples stored for 60 days (79.17\%) and 180 days (75.83\%) showed the best results. Therefore, we conclude that honey can be considered as a viable alternative for wort formulation for the production of spirit, mainly in the period between harvests of sugar cane, contributing to better utilization of the facilities and as alternative source of income for farmers.

Keywords: Honey spirit. Alcoholic fermentation. Yeast. 


\section{LISTA DE ILUSTRAÇÕES}

Figura 1 - Alambiques utilizados na produção da aguardente de mel

Figura 2 - Vista superior dos alambiques utilizados na produção da aguardente de mel

Figura 3 - Mapa de Preferência Interno referente ao atributo "impressão global" da aguardente armazenada em tonel de carvalho em diferentes tempos.........

Figura 4 - Dendrograma de similaridade entre as aguardente armazenadas em tonel de carvalho.

Figura 5 - Representação gráfica do teste de aceitação em relação à atitude de compra......

Figura 6 - Vista geral dos alambiques da Associação Rural de Canas. 


\section{LISTA DE TABELAS}

Tabela 1 - Composição química aproximada do mel.

Tabela 2 - Parâmetros de qualidade e identidade do mel produzido e comercializado no Mercosul.

Tabela 3 - Codificação das leveduras e sua origem.

Tabela 4 - Concentração de etanol (g/L) produzido pelas leveduras selecionadas, em mosto constituído de Mel $15{ }^{\circ}$ Brix suplementado, com diferentes nutrientes.

Tabela 5 - Açúcar consumido (\%) pelas leveduras selecionadas, em mosto constituído de Mel $15{ }^{\circ}$ Brix suplementado, com diferentes nutrientes.

Tabela 6 - Concentração celular $\left(\times 10^{7}\right)$ das leveduras selecionadas, em mosto constituído de Mel $15{ }^{\circ}$ Brix suplementado, com diferentes nutrientes

Tabela 7 - Parâmetros fermentativos referentes as leveduras selecionadas, em mosto constituído de Mel $15{ }^{\circ}$ Brix suplementado, com diferentes nutrientes........ 68

Tabela 8 - Identificação das leveduras

Tabela 9 - Caracterização do mosto e do vinho no processo de produção de aguardente de mel em escala piloto

Tabela 10 - Parâmetros fermentativos referentes ao desempenho da lelvedura $\mathrm{T}$ em processo de produção de aguardente de mel em escala piloto.

Tabela 11 - Caracterização físico química da aguardente de mel obtida em bateladas repetidas em dois alambiques de cobre.

Tabela 12 - Caracterização Físico Química da Aguardente de mel em diferentes tempos de descanso em tonel de carvalho.

Tabela 13 - Valores médios dos atributos de qualidade da aguardente de mel armazenada em diferentes tempos em tonel de carvalho

Tabela 14 - Descrição das frações “cabeça", "coração"e "cauda" obtidas nas cinco bateladas realizadas para a obtenção de aguardente de mel.

Tabela 15 - Padrões de identidade e qualidade para aguardente de cana e para cachaça

Tabela 16 - Padrões de identidade e qualidade para aguardente de frutas 
1. INTRODUÇÃ

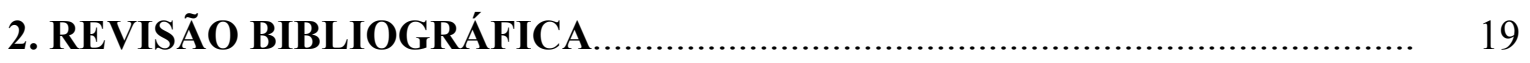

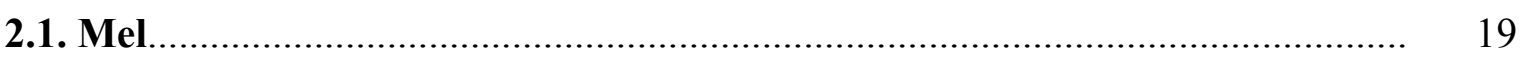

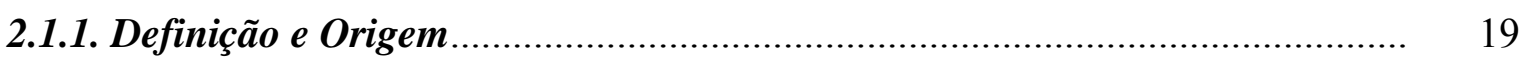

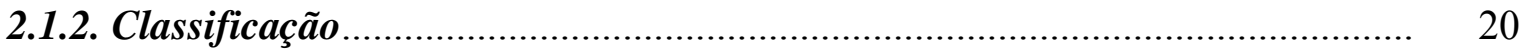

2.1.3. Composição e Qualidade do Mel...................................................................... 20

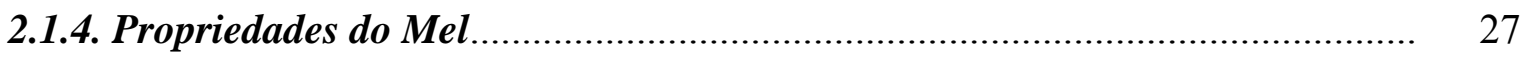

2.1.5. Microbiota Presente no Mel.................................................................... $\quad 30$

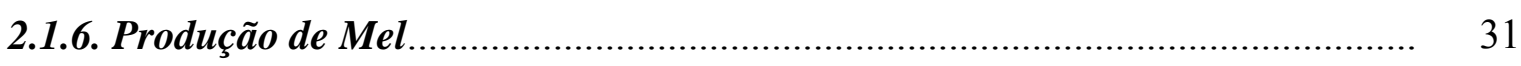

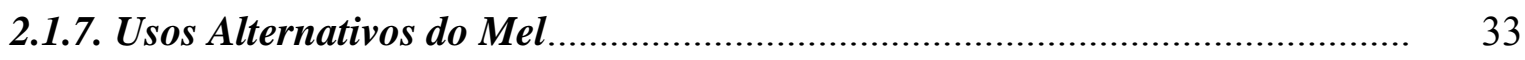

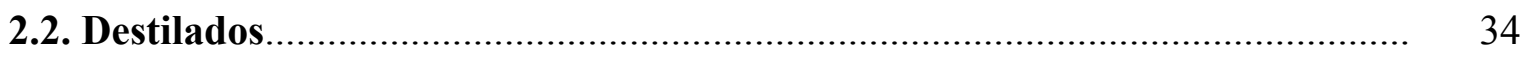

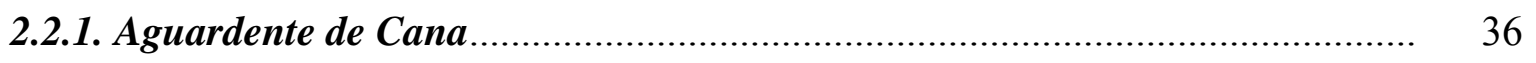

2.2.2. Aguardente de Frutas ............................................................................... 37

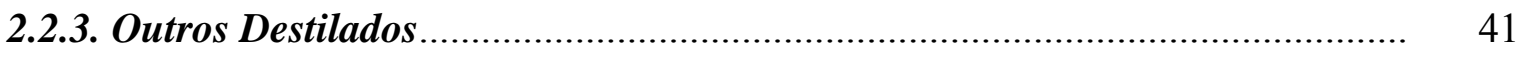

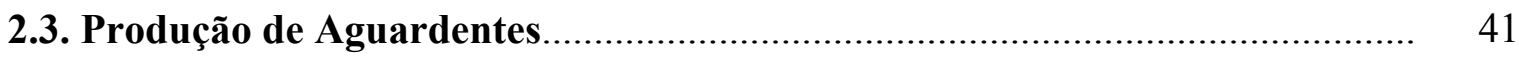

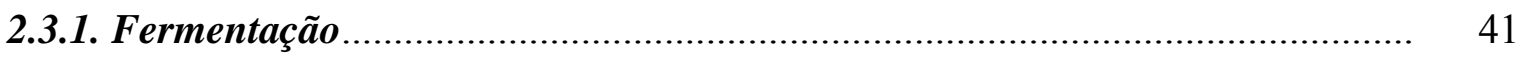

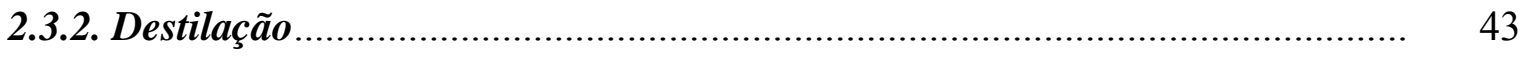

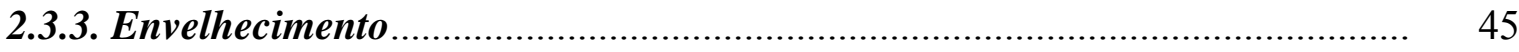

2.4. Fatores que Interferem na Qualidade do Destilado..................................... 48

3. MATERIAL E MÉTODOS .................................................................... 51

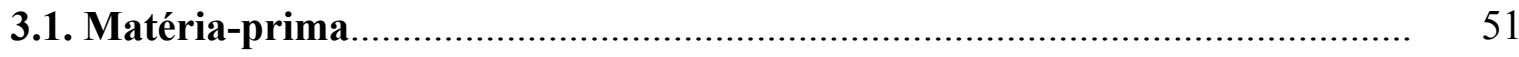

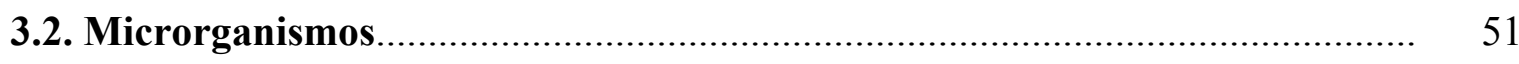

3.2.1. Isolamento das Leveduras....................................................................... $\quad 51$

3.2.2. Preparo do Inóculo.................................................................................. 52

3.3. Avaliação do Meio e Condições de Fermentação............................................ 52

3.4. Produção de Aguardente de Mel em Escala Piloto......................................... 53

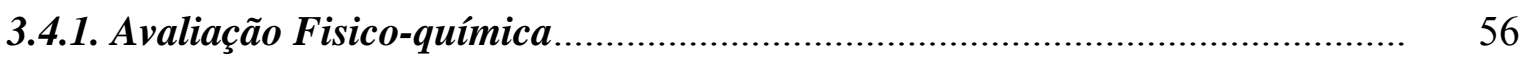


3.4.2. Avaliação Sensorial

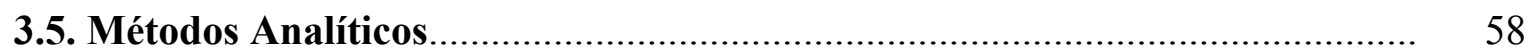

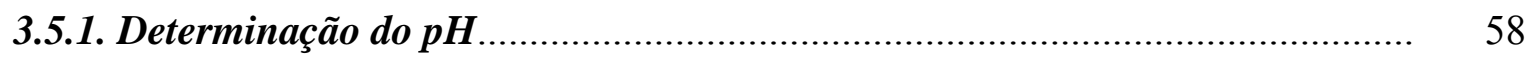

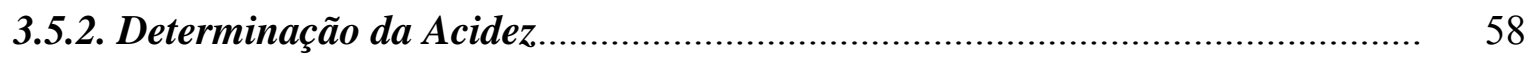

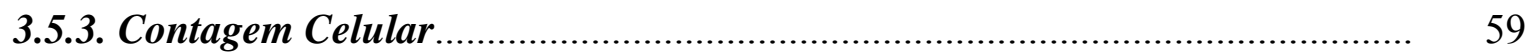

3.5.4. Determinação da Concentração de Açúcares e Etanol.....................................

3.6. Parâmetros Fermentativos.................................................................................... $\quad 60$

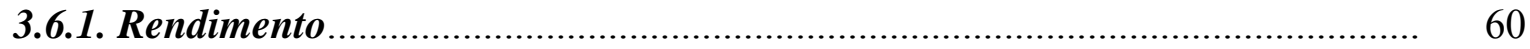

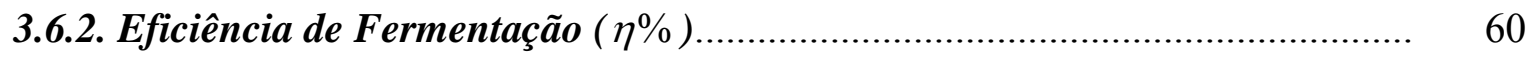

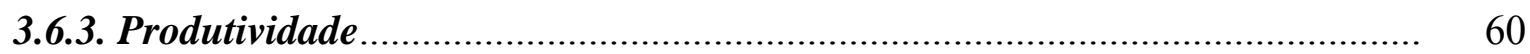

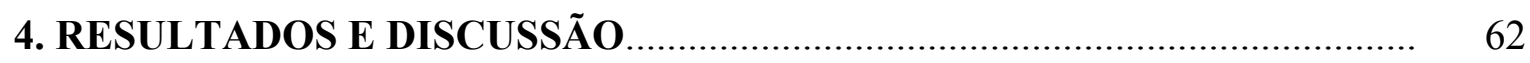

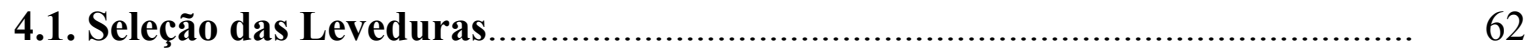

4.2. Produção de Aguardente de Mel em Escala Piloto........................................ $\quad 70$

4.3. Avaliação Fisico-química da Aguardente de Mel........................................... 73

4.4. Avaliação Sensorial da Aguardente de Mel.................................................... 93

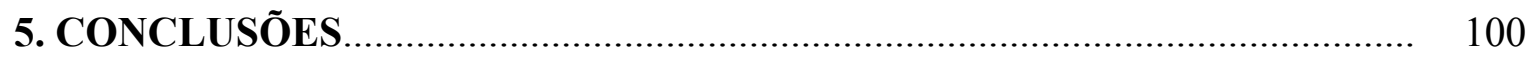

6. SUGESTÕES PARA TRABALHOS FUTUROS........................................... 101

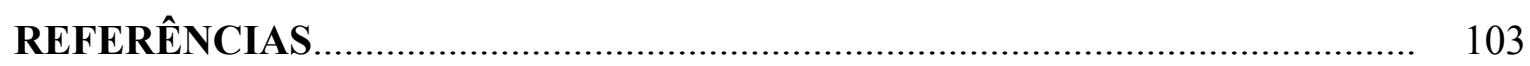

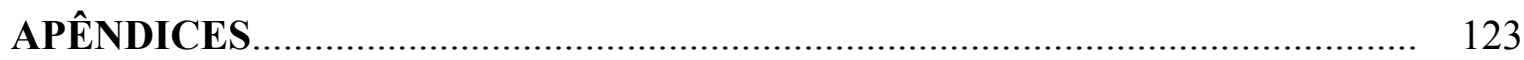

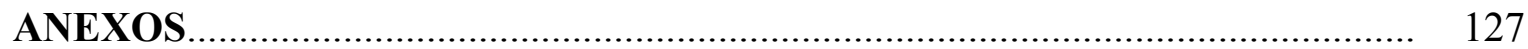




\section{INTRODUÇÃO}

O mel é um produto produzido pelas abelhas, e pode ser classificado como mel floral, se obtido do néctar das flores, ou mel de melato, se obtido de secreções de partes vivas das plantas ou de excreções de insetos sugadores de partes vivas das plantas. A qualidade do mel depende de diversos fatores como as condições climáticas, estágio de maturação, espécie da abelha, entre outros. Os principais constituintes do mel são os açúcares glicose e frutose e seu teor de água é o principal fator que irá influenciar na sua manutenção, qualidade e armazenamento.

O mel pode ser utilizado de diversas maneiras, dependendo da sua qualidade e composição. Como alimento, consumido in natura ou adicionado em produtos de panificação, balas, bolos e bebidas, e também como medicamento, devido às suas propriedades antioxidantes e anti-sépticas.

De acordo com SEBRAE (2010), o Brasil produz em média 40.000 toneladas de mel por ano, sendo grande parte destinada a exportação, principalmente para a Europa e EUA, a um preço médio de US\$ $2,88 / \mathrm{Kg}$. No entanto, em alguns estados o mel é vendido abaixo do preço médio de produção, como em Santa Catarina, onde o preço médio de venda foi de US\$2,57/Kg em julho de 2010. Além disso, parte do mel produzido não se enquadra nos padrões de qualidade exigidos pela legislação brasileira. Desde modo é importante a elaboração de co-produtos a partir do mel, visando aproveitar parte desta produção, agregando valor ao produto final. Dentre esses co-produtos destaca-se a aguardente de mel que tem sido produzida em escala artesanal cujos parâmetros que interferem na sua qualidade são pouco conhecidos.

As bebidas destiladas são obtidas a partir da destilação do mosto fermentado de frutas, cana de açúcar, melaço, cereal, vegetal, entre outros. As características do produto final dependem do substrato, bem como do processo de destilação empregado, das cepas de leveduras utilizadas e da composição do meio de fermentação. A graduação alcoólica das bebidas destiladas é superior à das bebidas fermentadas e, durante o processo de destilação, são separados os compostos denominados "componentes secundários", responsáveis pelas características sensorias da bebida.

O processo de envelhecimento das aguardentes é importante para o desenvolvimento de reações de oxidação e esterificação, reduzindo a concentração alcoólica do destilado e tornando o produto mais agradável do ponto de vista sensorial. A madeira comumente utilizada no envelhecimento é o carvalho e vários fatores como, tipo 
da madeira, tamanho do recipiente, temperatura, umidade do ar, são responsáveis pela qualidade da bebida envelhecida.

Outros fatores também interferem na qualidade do destilado como, a presença de cobre, compostos sulfurados, metanol e metais pesados, sendo importante avaliar as técnicas empregadas no processo de destilação, de modo a se obter um produto de qualidade, com características sensoriais agradáveis e dentro dos padrões estabelecidos na legislação em vigor.

Desta forma, o objetivo do presente trabalho foi contribuir para o desenvolvimento da Ciência e Tecnologia dos Alimentos com enfoque para a área de Tecnologia de Bebidas, no tocante ao desenvolvimento de um processo para produção de aguardente de mel. Para tanto, foram isoladas e caracterizadas leveduras a partir de diferentes espécies de frutas e mel, as quais foram avaliadas quanto ao desempenho fermentativo em mosto constituído de mel suplementado com diferentes nutrientes. O melhor isolado e meio de fermentação foram avaliados em escala piloto e, a aguardente produzida foi armazenada em tonel de carvalho, caracterizada e avaliada sensorialmente.

Desta maneira, por meio deste trabalho pretendeu-se, sustentando-se nos conhecimentos acumulados ao longo dos anos no tocante à fermentação alcoólica, contribuir para o desenvolvimento de um processo para produção de aguardente de mel, viabilizando assim a agregação de valor ao mel de baixa qualidade. 


\section{REVISÃO BIBLIOGRÁFICA}

\subsection{Mel}

\subsubsection{Definição e Origem}

De acordo com a Instrução Normativa $n^{\circ}$. 11, de 20 de outubro de 2000, do Ministério da Agricultura, Pecuária e Abastecimento (MAPA), mel é o produto produzido por abelhas melíferas, a partir do néctar das flores ou das secreções de plantas ou até mesmo de excreções de insetos sugadores de plantas que ficam sobre as mesmas, que as abelhas recolhem, transformam, combinam com substâncias específicas próprias, armazenam e deixam madurar nos favos da colméia (BRASIL, 2000).

Entende-se que mel é um produto da abelha, a única capaz de produzi-lo. Esta observação é importante, haja vista a elaboração artificial de certos produtos, como a glicose de milho, comercializados como mel, ou utilizados para sua adulteração (SILVA; QUEIROZ; FIGUEIRÊDO, 2004).

A criação racional de abelhas, constitui-se de uma atividade em que se consegue obter bons resultados econômicos, ecológicos e sociais. Essa atividade, desenvolvida ao longo do tempo por pequenos, médios e grandes produtores, vem despertando o interesse de muitos criadores e instituições do Brasil. (RODRIGUES et al., 2005).

As abelhas são insetos que pertencem á ordem Himenóptera, tendo surgido há mais de 50 milhões de anos e sempre presente em civilizações antigas como dos gregos e egípcios (ARAÚJO; SILVA; SOUSA, 2006). Existem abelhas solitárias, semi-sociais e sociais sendo a comunicação o principal fator que as distingue quanto a sua sociabilidade (MOURA, 2003).

Para a produção de mel, as abelhas usam como matéria-prima, principalmente, o néctar cuja origem advém do fluido circulante de plantas vasculares, sendo este fluido, que distribui nutrientes para o tecido vegetal, oriundo de dois sistemas: floema (sistema vascular que conduz matéria-orgânica) e xilema (sistema vascular que conduz água e minerais) (DE MARIA; MOREIRA, 2003). 


\subsubsection{Classificação}

O mel é classificado como floral se obtido a partir do néctar das flores, e classificado como mel de melato se for obtido de secreções de partes vivas das plantas ou de excreções de insetos sugadores de partes vivas das plantas (BRASIL, 2000). O mel de melato difere do mel floral em vários aspectos: por exemplo, o mel de melato possui menor teor de glicose, razão pela qual usualmente não cristaliza; este tipo de mel apresenta também menor teor de frutose, maior teor de oligossacarídeos e de cinzas, maior $\mathrm{pH}$ e maior teor de nitrogênio (CAMPOS et al., 2003).

A Legislação Brasileira classifica o mel proveniente de néctar de flores de uma mesma família, gênero ou espécie como sendo unifloral ou monofloral; e quando originado de diferentes tipos florais é denominado de multifloral ou polifloral (BRASIL, 2000).

De Maria e Moreira (2003) relatam que, a caracterização de um mel monofloral é baseada na identificação morfológica e quantificação dos grãos de pólen, os quais são carreados involuntarialmente junto com o néctar, quando da visita das abelhas aos nectários florais. Na prática, não é possível se obter um mel 100\% monofloral, ou seja, isento de grãos de pólen de outros espécimes. Os autores também afirmam que o aroma é um dos atributos sensoriais mais apreciados pelos consumidores de mel e o perfil de compostos voláteis representativos desse aroma serviria como método complementar para atestar a autenticidade do mel monofloral, bem como auxiliar no monitoramento da qualidade básica do produto.

\subsubsection{Composição e Qualidade do Mel}

Quando se trabalha com mel, é comum encontrar variações na sua composição física e química, tendo em vista que vários fatores interferem na sua qualidade, como condições climáticas, estágio de maturação, espécie de abelha, processamento e armazenamento, além do tipo de florada (SILVA et al, 2004). A composição química aproximada do mel está apresentada na Tabela 1.

De acordo com a Instrução Normativa 11, de 20 de outubro de 2000, do Ministério da Agricultura, Pecuária e Abastecimento (BRASIL, 2000), mel é uma solução concentrada de açúcares com predominância de glicose e frutose. Contém ainda uma mistura complexa de outros hidratos de carbono, enzimas, aminoácidos, ácidos orgânicos, 
minerais, substâncias aromáticas, pigmentos e grãos de pólen podendo conter cera de abelhas procedente do processo de extração.

Tabela 1 - Composição química aproximada do mel

\begin{tabular}{c|c}
\hline Nutrientes & Componentes presentes em 100g de mel \\
\hline Água & $17,1 \mathrm{~g}$ \\
\hline Carboidratos (totais) & $82,4 \mathrm{~g}$ \\
\hline Frutose & $38,5 \mathrm{~g}$ \\
\hline Glicose & $31 \mathrm{~g}$ \\
\hline Maltose & $7,2 \mathrm{~g}$ \\
\hline Sacarose & $1,5 \mathrm{~g}$ \\
\hline Proteínas, Aminoácidos, Vitaminas e Minerais & $0,5 \mathrm{~g}$ \\
\hline Energia & $304 \mathrm{Kcal}$ \\
\hline
\end{tabular}

Fonte: VENTURINI; SARCINELLI; SILVA, 2007.

Araújo, Silva e Sousa (2006) relatam que, após sua colheita o mel continua sofrendo modificações físicas, químicas e sensoriais, gerando a necessidade de produzi-lo dentro de níveis elevados de qualidade, controlando todas as etapas do seu processamento, afim de que se possa garantir um produto de qualidade. Os autores relatam também que o mel é um alimento apreciado por ter sabor característico e pelo seu considerável valor nutritivo, cuja oferta é bem menor que a procura, o seu preço é relativamente alto, o que incentiva por muitas vezes a sua adulteração, a qual é geralmente feita pela adição de açúcares comerciais, derivados de cana-de-açúcar e milho. Deste modo, sistematicamente, apicultores e consumidores têm demonstrado grande preocupação com a qualidade e com constantes adulterações de méis.

Lazaridou et al. (2004), estudaram a composição de açúcares de méis gregos selecionados, utilizando a técnica de Cromatografia Gasosa (CG) e determinaram que a frutose $(22,1-41,3 \%)$ e a glicose $(13,5-36,3 \%)$ foram os principais açucares encontrados, sendo a frutose sempre mais abundante. Os méis com menor porcentagem de frutose e glicose corresponderam àqueles com origem não-floral, isto é, mel de melato. Dentre os dissacarídeos, maltose foi o mais abundante, variando entre 1,9\% e 6,7\%. Os níveis relativamente baixos de sacarose encontrados para a maioria das amostras indicam que os méis foram selecionados em um estágio avançado de maturação. Os autores relatam que 
vários trissacarídeos também foram identificados e quantificados, entre eles, rafinose, erlose, melezitose, panose, isomaltotriose e maltotriose. Os autores observaram que a melezitose esteve presente em quantidades relativamente altas $(9,1-14,4 \%)$ na maioria das amostras de mel de melato.

Segundo Lazaridou et al. (2004), a maioria dos méis são soluções supersaturadas de glicose, que têm uma tendência a cristalizar-se espontaneamente à temperatura ambiente, sob a forma de glicose monohidratada. A cristalização do mel, comumente chamada de granulação, é um processo indesejável no mel em estado líquido, pois afeta as propriedades texturais, tornando-o menos atraente para o consumidor. Além disso, em muitos casos, a cristalização do mel resulta em aumento do teor de água da fase líquida, o que pode permitir que naturalmente células de levedura se multipliquem, causando a fermentação do produto.

A molécula de água está presente no mel principalmente ligada a açúcares, por meio de ligações de hidrogênio (GLEITER; HORN; ISENGARD, 2006). No mel cristalizado há formação de cristais de glicose principalmente, sob a forma de glicose monohidratada, a frutose é mais solúvel e permanece em solução por mais tempo (ASSIL; STERLING; SPORNS, 1991). Durante o processo de cristalização do mel, a água que estava ligada à molécula de glicose é liberada, desta forma, a atividade de água aumenta (GLEITER; HORN; ISENGARD, 2006).

A atividade de água do mel varia de 0,5 a 0,65. A atividade de água necessária para o desenvolvimento de microrganismos é inferior a 0,98 e depende da classe de microrganismos, sendo em torno de 0,70 para fungos, 0,80 para leveduras e 0,90 para bactérias. Leveduras osmofílicas conseguem se desenvolver em meios contendo alta concentração de açúcar e baixa atividade de água, em torno de 0,60, podendo causar a fermentação do mel (GLEITER; HORN; ISENGARD, 2006). O teor de água, bem como atividade de água são os principais fatores que influenciam a manutenção da qualidade ou capacidade de armazenamento do mel (LAZARIDOU et al., 2004).

Gleiter, Horn e Isengard (2006) investigaram a influência dos diferentes tipos de mel e também do estado físico em que se encontram, líquido ou cristalizado, na sua atividade de água e, como resultado, os autores mostraram que a atividade de água do mel cristalizado é mais elevada do que a do mel líquido. Além disso, detectaram diferenças entre os méis de melato e os méis de florata. No estado líquido, o mel de melato apresenta maior atividade de água do que o mel de florata, com o mesmo teor de água. No entanto, não houve diferença significativa entre as atividades de água dos diferentes tipos de mel, 
quando estes estão no estado cristalizado. Os autores afirmam ainda que, a atividade de água do mel depende principalmente do teor de glicose.

As análises físico-químicas do mel puro de Apis mellifera indicadas pela legislação brasileira compreendem aspectos quanto à sua maturidade (açúcares redutores, umidade e sacarose aparente), pureza (sólidos insolúveis em água, minerais ou cinzas, pólen), e deterioração (acidez, atividade diastásica e hidroximetilfurfural) (BRASIL, 2000).

Os valores preconizados nas normas vigentes (BRASIL, 2000) podem ser verificados na Tabela 2 e foram estabelecidos como requisitos para consumo humano, do mel destinado ao comércio nacional e internacional (ARRUDA et al., 2004).

Tabela 2 - Parâmetros de qualidade e identidade do mel produzido e comercializado no Mercosul.

\begin{tabular}{l|c|c}
\hline \multicolumn{1}{c|}{ Parâmetro } & \multicolumn{2}{c}{ Especificações } \\
\hline Açúcares Redutores (\%) & Mel Floral & Mel de Melato \\
\hline Sacarose Aparente (\%) & Máximo 65 & Máximo 15 \\
\hline Umidade (\%) & Máximo 20 & Máximo 20 \\
\hline Sólidos Insolúveis (\%) & Máximo 0,1 & Máximo 0,1 \\
\hline Acidez (mEq.kg-1) & Máximo 50 & Máximo 50 \\
\hline Minerais (\%) & Máximo 0,6 & Máximo 1,2 \\
\hline Atividade Diastásica (escala Göthe*) & Mínimo 8; ou 3 se HMF & Mínimo 8; ou 3 se HMF \\
& inferior a 15 & inferior a 15 \\
\hline Hidroximetilfurfural (mg.kg ${ }^{-1}$ ) & Máximo 60 & Máximo 60 \\
\hline
\end{tabular}

Fonte: BRASIL, 2000.

* a quantidade de enzima necessária para converter em uma hora à $40^{\circ} \mathrm{C} 0,01$ gramas de amido.

Os méis são ácidos, com pH variando geralmente entre 3,5 e 5,5, devido a presença de ácidos orgânicos que contribuem para o sabor e para sua estabilidade frente à deteriorização microbiana (BOGDANOV; RUOFF; ODDO, 2004; AROUCHA et al, 2008). Encontram-se presentes no mel os seguintes ácidos orgânicos: acético, butírico, cítrico, fórmico, glucônico, láctico, entre outros (CORTOPASSI-LAURINO; GELLI, 1991). A acidez do mel deve-se à variação destes ácidos orgânicos, a qual é causada pelas diferentes fontes de néctar, pela ação da enzima glicose-oxidase que origina o ácido 
glucônico, pela ação das bactérias durante a maturação do mel e ainda a quantidade de minerais presentes (ARAÚJO; SILVA; SOUSA, 2006). O principal ácido do mel é o ácido glucônico, o qual é encontrado juntamente com seu respectivo glucono-lactona em um equilíbrio variável (BOGDANOV; RUOFF; ODDO, 2004).

O conteúdo de ácido orgânico no mel influencia sua velocidade de fermentação e frequentemente faz com que o mesmo pare de fermentar. Esse fenômeno, é causado principalmente pela formação do ácido succínico, e é fortemente dependente da cepa de levedura utilizada e da presença de compostos de nitrogênio (SROKA; TUSZYNSKI, 2007).

Aroucha et al. (2008) avaliaram alguns parâmetros de qualidade do mel de abelha (Apis mellífera L.) produzidos e comercializados no município de Mossoró-RN. Os valores médios de acidez total das amostras de méis analisadas variaram entre 31,25 a 86,75 meq $/ \mathrm{kg}$, sendo que cerca de 57,88\% das amostras apresentaram-se dentro do padrão exigido pela legislação brasileira.

Araújo, Silva e Sousa (2006) em estudo onde avaliaram a qualidade dos méis comercializados na Cidade de Crato-CE encontraram teores de acidez de 21,57 a $59,6 \mathrm{meq} / \mathrm{kg}$. O índice de acidez elevado, de 59,6meq/kg, está acima do limite estabelecido pela legislação (BRASIL, 2000) e indica um mel com início de fermentação. A porcentagem de méis com acidez total acima do limite permitido pode ser uma variável relacionada à origem botânica, armazenamento inadequado e processo de fermentação (AROUCHA et al, 2008).

Silva, Queiroz e Figueirêdo (2004) encontraram valores de acidez variando entre 10,10 e $31,03 \mathrm{meq} / \mathrm{kg}$ de mel, valores estes que estão dentro dos padrões de qualidade recomendados pela legislação.

A prolina é um dos aminoácidos mais abundantes no pólen de muitas espécies vegetais (FERREIRA; ALBUQUERQUE, 1990). E, de acordo com Kessler (2003), a Lprolina é um aminoácido não essencial em crianças e adultos e condicionalmente essencial em prematuros. Enquanto a D-prolina não ocorre naturalmente no metabolismo humano.

Dentre os aminoácidos encontrados no mel, a prolina é o que está presente em maior quantidade, representando cerca de 50-85\% do total (WHITE JÚNIOR; RUDYJ, 1978; SODRÉ, 2005). Este aminoácido é sintetizado pela abelha e seu teor é utilizado como critério de avaliação da maturação do mel (BOGDANOV; RUOFF; ODDO, 2004). 
Por meio da determinação de cinzas é possível detectar algumas irregularidades no mel, como a contaminação provocada pela falta de decantação e/ou pela filtração no final do processo de extração, pois os processos de filtração e decantação servem para retirar as impurezas do mel (SILVA; QUEIROZ; FIGUEIRÊDO, 2004). O teor de cinzas também é um critério de qualidade que depende da origem botânica do mel, sendo que os méis florais apresentam um teor de cinzas inferior ao teor de cinzas dos méis de melato (BOGDANOV et al, 2000). Além disso, os minerais têm importância nutricional e afetam a cor dos méis (DOWNEY et al, 2005).

As enzimas comumente encontradas nos méis são $\alpha$-glicosidase (invertase), $\alpha$ amilase e $\beta$-amilase (diastase), glicoseoxidase e, em menores concentrações, a catalase e a fosfatase (BARHATE et al., 2003; VORLOVA; CELECHOVSKA, 2002).

A diastase e a invertase são enzimas nutricionalmente importantes. A diastase hidrolisa carboidratos de fácil digestibilidade enquanto a invertase hidrolisa a sacarose, liberando glicose e frutose (BARHATE et al., 2003; MOREIRA; DE MARIA, 2001). A frutose e a glicose existentes no mel podem estar presentes, em maior ou menor grau, na excreção dos insetos que sugam o fluido do floema, no caso dos méis de melato, ou podem ser produzidos pela inversão da sacarose pela ação da enzima invertase (MOREIRA; DE MARIA, 2001).

Segundo Camargo et al. (2003), a enzima invertase secretada pelas abelhas transforma 3/4 da sacarose inicial do néctar coletado, nos açúcares invertidos glicose e frutose, ao mesmo tempo, que estes açúcares são sintetizados. Sua ação é contínua até que o "amadurecimento" total do mel ocorra. Dessa forma, pode-se definir o amadurecimento do mel como a inversão da sacarose do néctar pela enzima invertase e sua simultânea mudança de concentração.

Ainda, de acordo com Camargo et al. (2003), a invertase irá permanecer no mel conservando sua atividade por algum tempo, a menos que seja inativada pelo aquecimento; mesmo assim, o conteúdo da sacarose do mel nunca chega a zero. Essa inversão de sacarose em glicose e frutose produz uma solução mais concentrada de açúcares, aumentando a resistência do mel à deterioração por fermentação.

Ainda que as enzimas sejam secretadas pelas abelhas, os diversos tipos de méis apresentam diferenças consideráveis na atividade enzimática (ODDO; PIRO, 2004), provavelmente devido à taxa do fluxo do néctar e ao estágio fisiológico das glândulas das abelhas durante as estações produtivas (BOGDANOV; RUOF; ODDO, 2004). 
Segundo Aroucha et al. (2008), a atividade diastásica é importante por indicar a pureza do mel e diminui devido à desnaturação parcial ou total das amilases. A ausência da mesma reflete procedimentos e/ou adulterações realizadas no mel, tal como uso de temperatura acima de $60^{\circ} \mathrm{C}$ durante o beneficiamento, adição de açúcar invertido e condições de armazenamento inadequadas, como tempo superior a seis meses e temperaturas elevadas. A legislação permite um valor mínimo de atividade diastásica igual a 8 na escala Gothe (BRASIL, 2000), onde a unidade de Gothe é definida como a quantidade de enzima necessária para converter em uma hora à $40^{\circ} \mathrm{C} 0,01$ grama de amido, e os resultados são expressos em unidades Gothe por grama de mel (BOGDANOV, 2002).

A formação de 5-hidroximetilfurfural (HMF) no mel, bem como em vários outros alimentos, deve-se à desidratação das hexoses catalisada por ácidos (SILVA et al, 2008). A presença no mel de açúcares simples e água em meio ácido fornece condições favoráveis à formação desse composto furânico (NOZAL et al., 2001; SILVA et al, 2008).

O estudo da presença do HMF em alimentos tem recebido atenção porque este composto e seus derivados, 5-clorometilfurfural e 5-sulfoximetilfurfural, têm apresentado atividade citotóxica, genotóxica, mutagênica e carcinogênica (TEIXIDÓ et al., 2006).

O teor de HMF é um indicador de qualidade e não está diretamente relacionado à origem floral e/ou geográfica (BENDINI; SOUZA, 2008). O mel recém-colhido contém pequena quantidade de $\mathrm{HMF}$, mas com o armazenamento prolongado em temperatura ambiente alta e/ou superaquecimento este teor se eleva (MENDES et al, 1998; SILVA; QUEIROZ; FIGUEIRÊDO, 2004). O teor de HMF também pode ser mais elevado em méis adulterados por adição de açúcar invertido (SILVA; QUEIROZ; FIGUEIRÊDO, 2004). Caso isso ocorra, o mel terá seu valor nutricional alterado (ARAÚJO; SILVA; SOUSA, 2006).

Vários fatores influenciam a formação de HMF no mel: a temperatura e o tempo de aquecimento, o uso de embalagens metálicas e as propriedades químicas do mel, as quais estão relacionados com a origem floral. Estas propriedades são acidez, pH total e o conteúdo mineral. No entanto, não está disponível nenhuma informação sobre a correlação entre as características químicas do mel e o nível de HMF (FALLICO et al., 2004).

O processamento do mel frequentemente requer aquecimento para reduzir a sua viscosidade, modificando a sua tendência à cristalização ou retardando o seu aparecimento, e também para destruir microrganismos contaminantes e prevenir a fermentação 
(FALLICO et al., 2004; TOSI; CIAPPINI; LUCERO, 2002). Porém, este aquecimento favorece a formação de HMF (DOWNEY et al., 2005).

A legislação brasileira permite um máximo de $60 \mathrm{mg}$ de HMF/kg de mel (BRASIL, 2000). A recomendação do Codex Alimentarius prevê que o conteúdo de HMF não deve exceder $80 \mathrm{mg}$ de $\mathrm{HMF} / \mathrm{kg}$ de mel, para méis provenientes de países tropicais, pois nos países quentes o teor de HMF do mel tende a aumentar mais rapidamente durante o armazenamento (FALLICO et al., 2004).

De acordo com o Regulamento Técnico de Identidade e Qualidade do mel (BRASIL, 2000), o mel não deve conter substâncias estranhas, de qualquer natureza, tais como insetos, larvas, grãos de areia e outros. Sousa e Carneiro (2008), ao avaliarem o perfil microscópico da qualidade do mel de abelhas produzido no Piauí, detectaram a presença de larvas, ácaros e fragmentos de insetos, além de pêlos humanos e de roedores entre as amostras analisadas.

A cor é uma das características do mel que mais influencia na preferência do consumidor e no preço de mercado, sendo que geralmente, os méis mais claros apresentam maiores valores no mercado externo (AROUCHA et al., 2008). A legislação brasileira define que a cor do mel é variável de quase incolor a pardo-escura, conforme sua classificação de acordo com sua origem (BRASIL, 2000). De acordo com CortopassiLaurino e Gelli (1991) a cor mais escura é uma característica dos méis que contêm maiores quantidades de açúcares redutores.

\subsubsection{Propriedades do Mel}

O homem tem utilizado o mel de diversas maneiras, seja como alimento, ou como medicamento, devido às suas propriedades anti-sépticas e, ainda, como conservante de frutas e grãos (CORTOPASSI-LAURINO; GELLI, 1991).

O mel é um produto de origem animal de alto valor nutritivo e com propriedades medicinais, como por exemplo antioxidativa e asséptica, geralmente relacionadas à presença de compostos fenólicos e à enzima glicose oxidase, a qual catalisa a oxidação da glicose, com concomitante produção de peróxido de hidrogênio, um forte agente oxidante que ataca o envoltório de microrganismos (DE MARIA; MOREIRA, 2003). 
Além de agirem na prevenção ou retardamento da oxidação de alimentos, os antioxidantes também exercem importante papel na prevenção ou retardamento das doenças degenerativas (YEPES et al., 2002; CAMPOS et al, 2008).

Diversos estudos têm comprovado a ação terapêutica do mel, existindo atualmente interesse em avaliar a sua capacidade antioxidante (SERRA, 2007). O mel apresenta na sua constituição compostos que lhe podem conferir propriedades antioxidantes tais como os polifenóis e os flavonóides (SERRA, 2007). Alguns destes compostos já foram identificados no mel como os ácidos cinâmico, cafeico, ferúlico e cumárico, a quercetina, a crisina e o canferol (TOMÁS-BARBERÁN et al., 2001).

Mckibben e Engeseth (2002) avaliaram a eficácia do mel de diferentes fontes florais, como um inibidor da oxidação lipídica em carne de peru moída e comparam o seu teor antioxidante frente a outros antioxidantes comumente utilizados. Estes autores verificaram que méis de diferentes fontes florais diferem na sua proteção contra a oxidação lipídica, e todos os méis analisados mostraram-se mais eficazes do que os antioxidantes tocoferol e BHT, comumente utilizados. Além de ser uma fonte natural de antioxidantes, o mél também contribui para um melhor sabor da carne.

Phillips, Carlsen e Blomhoff (2009), avaliaram o conteúdo de antioxidantes em adoçantes naturais alternativos ao açucar refinado e, dentre os adoçantes naturais estudados, o mel apresentou capacidade antioxidante intermediária.

Henriques (2004) relata que, inicialmente pensava-se que as propriedades antibacterianas do mel fossem essencialmente devidas ao fato deste ser uma solução muito concentrada de açúcares e possuir um $\mathrm{pH}$ relativamente baixo, entre 3,0 e 5,0, fatores estes que restringem o crescimento de muitas espécies de microrganismos. No entanto, existem microrganismos capazes de sobreviver em ambientes onde há um grande stress osmótico. Existem também microrganismos capazes de sobreviver em $\mathrm{pH}$ bastante baixos que pareciam não resistir ao mel, como é o caso do Staphylococcus aureus. Além disso, quando mel artificial foi usado, ou seja, uma mistura de açúcares na proporção presente no mel e pH correspondente, esta mistura, embora inibisse muitos microrganismos, necessitava de concentrações mais altas do que as concentrações de mel natural, logo, estava presente no mel alguma outra substância que lhe conferia a atividade antibacteriana. Esse componente foi denominado "inhibine" (BOGDANOV, 1997), mais tarde identificado como sendo o peróxido de hidrogênio.

Existem dois tipos de agentes antibacterianos no mel (BOGDANOV, 1997). Um peróxido, que é destruído quando o mel é aquecido ou armazenado sob a luz e o outro é 
um composto não peróxido que é estável ao aquecimento e armazenamento (WHITE JÚNIOR.; SUBERS, 1964).

O principal responsável pela atividade antibacteriana do mel é o peróxido de hidrogênio, que é formado a partir da oxidação da glicose pela enzima glicose oxidase, durante o período de amadurecimento do mel (WESTON; MITCHELL; ALLEN, 1999; BARHATE et al., 2003). Devido a sua atividade antimicrobiana, o mel pode ser utilzado no tratamento de feridas e doenças gastrointestinais, tais como dispepsia, gastroenterite bacteriana, úlceras gástricas e duodenais (BARHATE et al., 2003).

Molan e Russel (1988) analisaram méis monoflorais da Nova Zelândia com e sem a presença de peróxido de hidrogênio (inativada pela ação da catalase), quanto a sua atividade antibacteriana. Os autores verificaram que em méis com alta atividade antibacteriana, grande parte desta atividade foi devido a um outro fator que não o peróxido de hidrogênio. Foi avaliada a resistência do microrganismo Staphylococcus aureus e verificou-se que este não foi inibido pela osmolaridade ou acidez do mel. Os autores concluiram que a associação de alta atividade antibacteriana com fontes florais específicas sugere que a atividade antibacteriana do composto não peróxido é de origem floral. A atividade antibacteriana do mel foi testada e verificou-se ser estável ao aquecimento.

Allen, Molan e Reid (1991), para avaliar a variação da atividade antibacteriana do mel, fizeram um levantamento em 345 amostras de mel não pasteurizado obtido a partir de apicultores comerciais da Nova Zelândia. A maioria dos méis foi considerada monofloral, de 26 diferentes fontes florais. Os méis foram testados contra Staphylococcus aureus em um ensaio de difusão em ágar. Uma menor atividade não foi associada com a idade das amostras de mel e nem com o tipo de processamento realizado ao mel, pelo apicultor. No entanto, a diferença entre as fontes florais na atividade antibacteriana foi altamente significativo. Quando a atividade antibacteriana foi testada com catalase adicionada para remover o peróxido de hidrogênio, a maioria dos méis não apresentaram atividade detectável. Apenas os méis provenientes das fontes florais manuka (Leptospermum scoparium J. R. et G. Forst. Família: Myrtaceae) e víboras bugloss (Echium vulgare L. Família: Boraginaceae) apresentaram atividade em parte significativa das amostras. A alta atividade antibacteriana do mel proveniente da fonte floral manuka foi, em muitos casos devido inteiramente ao componente não-peróxido.

A atividade antimicrobiana do mel contra bactérias potencialmente patogênicas foi avaliada in vitro por Tajik, Jalali e Javadi (2008). Comparado ao efeito dos antibióticos da família da penicilina, o halo de inibição formado pelo uso do mel foi maior do que outros 
antibióticos para bactérias gram negativas, como Salmonella typhimurium e Escherichia coli.

Racowshi et al. (2007) estudaram a ação antimicrobiana do mel em leite fermentado, determinando a faixa de concentração ideal para inibição de bactérias mesófilas. Os resultados mostraram que o mel apresenta efeito inibidor sobre os microrganismos do leite fermentado, sendo a concentração de mel ideal encontrada entre $1,5 \%$ e $2,5 \%$, e verificaram também que esta inibição foi melhor em bactérias Gram positivas.

\subsubsection{Microbiota Presente no Mel}

De acordo com Snowdon e Clivef (1996), as espécies de microrganismos encontrados no mel são divididos em três categorias: (1) microrganismos que são encontrados naturalmente no mel; (2) microrganismos que indicam qualidade sanitária e comercial; (3) microrganismos que, sob determinadas condições, poderiam causar doenças ou intoxicações.

Ragazani et al. (2008) realizaram um estudo com o objetivo de avaliar a qualidade microbiológica do mel comercializado em seis Estados brasileiros (São Paulo, Mato Grosso, Goiás, Ceará, Minas Gerais e Santa Catarina), verificando a presença de esporos de Clostridium botulinum neste produto alimentar. Em 7\% das amostras de mel comercial foi detectada a presença do Clostridium botulinum, realçando a relevância deste microrganismo para a saúde pública devido ao risco do mel comercializado nestas regiões causar o botulismo infantil, especialmente em crianças com idade menor que 1 ano.

Para determinar o efeito da radiação gama sobre os microrganismos do mel, Jo et al. (2005) irradiaram 4 tipos de mel e realizaram a contagem total de bactérias aeróbias, bolores e leveduras, coliformes e Clostridium spp. Em todos os méis, a contagem de coliformes, leveduras e fungos foi abaixo do limite de detecção ( $\leq 10 \mathrm{UFC} / \mathrm{g})$. A contagem de bactérias aeróbias totais e Clostridium spp variou de 85-450 UFC/g e 0-450 UFC/g, respectivamente. Dois tipos de méis estudados foram completamente esterilizados por irradiação e ambos apresentaram redução da população total de bactérias aeróbias e Clostridium spp. Deste modo, os autores concluiram que o tratamento por irradiação pode ser um instrumento eficaz para a desinfecção do mel. 
Ruiz-Argueso e Rodriguez-Navarro (1975) ao avaliarem a microbiota de méis em diferentes estágios de amadurecimento observaram a predominância de dois principais grupos de bactéria: Gluconobacter e Lactobacillus, cuja presença no mel é reduzida à medida que este vai amadurecendo. Ocasionalmente foi isolado um terceiro grupo de bactérias, classificadas como Zymomonas, e vários tipos de leveduras.

Em 1976, Munitis, Cabrera e Rodriguez-Navarro, em estudo sobre a microbiota de um mel de origem espanhola, isolaram uma levedura considerada pelos autores como osmofílica obrigatória. A levedura foi identificada como Saccharomyces bisporus var. mellis, a qual apresentou um máximo de crescimento a $60 \%$ de glicose. Sendo que, abaixo de $10 \%$ esta espécie não apresentou crescimento.

\subsubsection{Produção de Mel}

Segundo Pereira et al. (2003) a produção mundial de mel apresentou uma tendência crescente desde 1983, apesar das flutuações, em regiões e países industrializados e nãoindustrializados, atribuídas a um aumento no número de colméias e da produção por colônia. Além disso, o consumo também aumentou, sendo atribuído ao aumento geral nos padrões de vida e também a um interesse maior em produtos naturais e saudáveis.

O mel é um alimento apreciado por seu sabor característico e pelo seu considerável valor nutritivo, no qual sua oferta é bem menor que a procura, o seu preço é relativamente alto, o que incentiva por muitas vezes a sua adulteração, a qual é geralmente feita pela adição de açúcares comerciais, derivados de cana-de-açúcar e milho (ARAÚJO; SILVA; SOUZA, 2006). O Brasil possui reservas florais que podem proporcionar milhares de toneladas de mel, de primeira qualidade, aceito pelo mercado mais exigente (WIESE ${ }^{1}$, 1982 apud ARAÚJO; SILVA; SOUZA, 2006, p. 52).

Devido a uma flora bastante diversificada, uma extensão territorial invejável e uma variabilidade climática marcante, o Brasil tem um grande potencial apícola, possibilitando produzir mel o ano todo, o que o diferencia dos demais países que, normalmente, colhem mel uma vez por ano (ARRUDA et al., 2004).

\footnotetext{
${ }^{1}$ WIESE, Helmuth. Apicultura. Brasília: Empresa Brasileira de Assistência Técnica e extensão Rural. In: LIMA, Nelson Mello. Abelhas e mel: criação - extração. São Paulo: Ediouro, 1979. (Embrater), 1982.
} 
Segundo Arruda et al. (2004) o Nordeste brasileiro é uma região promissora para desenvolvimento de grandes projetos apícolas, uma vez que proporciona um pasto apícola sem qualquer contaminação química, com possibilidade de obter o mel orgânico, livre de agrotóxicos e medicamentos. A apicultura tem desenvolvido importante papel econômico, social e ecológico no Nordeste brasileiro porque gera renda aos agricultores, ocupa a mãode-obra familiar e contribui para o aumento da diversidade biológica do ecossistema. Os Estados do Piauí e Ceará se destacam na produção de mel, devido aos seus recursos naturais.

No Nordeste brasileiro, em especial nos Estados do Ceará, Piauí e Rio Grande do Norte, é produzido o mel monofloral obtido do cajueiro (Anacardium occidentale L.), sendo este mel comercializado no mercado nacional e internacional (BENDINI; SOUZA, 2008).

Campos et al. (2003) relatam que em Santa Catarina é encontrado o mel de melato do caule da bracatinga (Leguminosae mimosoideae Mimoso sp), produzido de dois em dois anos, época que corresponde ao ciclo da cochonilha. Além da bracatinga há também produção de melato a partir do ingá. Segundo os autores, na década de 80, o entreposto de mel e cera de abelhas "Colonial de Itajaí"- SC iniciou a exportação do produto para a Alemanha, a fim de ser utilizado na elaboração de fármacos. No final de 2000, o entreposto de mel e cera de abelha "Miramel" Ltda., Içara - SC, conseguiu exportar para a Alemanha este mesmo mel por US\$ 1400 a tonelada, contra US\$ 1100 a tonelada do mel floral.

A produção apícola nacional triplicou nos últimos anos e em 2007, com 40.000 toneladas anual, o Brasil foi o $11^{\circ}$ produtor no ranking mundial, conquistando posição de destaque no mercado externo e o $5^{\circ}$ maior exportador, passando de 269 toneladas de mel exportadas em 2000, para 21.000 toneladas em 2005 (CBA, 2007). A produção mundial de mel é bastante fragmentada por país, mas a China merece destaque por ocupar posição de liderança isolada com $20 \%$ do mel produzido, sendo seguida pelos Estados Unidos e pela Argentina (ADAMS, 2006).

Segundo Luz (2010), o consumo de mel no Brasil está estimado em aproximadamente $200 \mathrm{~g} /$ pessoa/ano, o que é considerado muito baixo se comparado a alguns países da Europa, como a Alemanha e Suíça, onde se calcula um consumo de $2.400 \mathrm{~g} / \mathrm{pessoa} / \mathrm{ano}$. O mercado apícola nacional é bastante atrativo, seu desenvolvimento é notável, porém sofre a influência do mercado internacional e principalmente do Mercosul. O Brasil produz em média 40.000 toneladas de mel por ano, mas consome 60.000 , gerando um déficit de produção de 20.000 para o mercado interno, o que torna a apicultura um 
negócio rentável, principalmente porque estudos das principais associações brasileiras de produtores de mel indicam que existe potencialidade para se alcançar, sem muitos investimentos, 200.000 ton/ano.

De acordo com SEBRAE (2010), em julho de 2010, as exportações de mel tiveram aumento de 4,2\% em valor e de 5,4\% em peso. Entretanto, quando comparado com julho de 2009 , ocorreu um incremento $14 \%$ na receita de exportação. O preço médio do mel foi US\$ 2,88/kg. Em julho de 2010, a liderança nas exportações de mel continuou com o Estado de São Paulo, respondendo por um terço (33,2\%) das exportações brasileiras. O segundo colocado foi o Rio Grande do Sul e o terceiro exportador foi o Ceará. Santa Catarina foi o oitavo e último exportador. Os estados que comercializaram o mel com preços acima da média foram Paraná, Ceará e Piauí. Em julho de 2010, os Estados Unidos continuaram sendo o principal mercado, absorvendo $74,4 \%$ do mel brasileiro exportado, a um preço de US\$2,83/kg. A Alemanha, foi o destino de 10,2\% do mel brasileiro exportado em julho/2010, a um preço de US\$3,04/kg.

\subsubsection{Usos Alternativos do Mel}

Almeida e Carvalho (2009) relatam que além da vasta utilização na indústria alimentícia, principalmente como ingrediente na mistura em alguns produtos, como iogurte e biscoitos, o mel tem sido testado com êxito, principalmente devido às suas qualidades anti-sépticas e cicatrizantes. Além disso, a indústria de higiene e cosméticos, também tem utilizado o mel como base para diversos produtos como: xampus, condicionadores, sabonetes, cremes, loções e óleos.

De acordo com Brownig, Walker III e Hansen (2010), o uso do mel na produção de cerveja fornece açúcares fermentescíveis, contribui com um aroma e sabor próprio, além de agregar valor à bebida por ser um atrativo a mais para o consumidor. Segundo os autores, do ponto de vista técnico, praticamente qualquer tipo de mel pode ser usado no processo de fabricação de cerveja e cada tipo de mel contribui com algo diferente em relação às características sensoriais do produto final. Para os cervejeiros, o mel é considerado como um ingrediente funcional de alto valor, e não apenas um adjunto da indústria cervejeira. O impacto que o mel causará nas características sensoriais da cerveja vai depender da etapa do processo em que o mel será adicionado, do tipo de cerveja que se 
pretende produzir, da quantidade de mel a ser acrescentado e do tipo de mel utilizado. Segundo os autores, estudos de análise sensorial de cervejas com mel revelaram que o mel diminui a percepção de acidez e sabor amargo na bebida.

Hidromel é uma bebida fermentada a base de mel, que também recebe o nome de vinho de mel e melomel é um tipo de hidromel, acrescido de suco de frutas (BROWNING; WALKER III; HANSEN, 2010). A produção de hidromel é realizada desde tempos antigos, entretanto, este produto é ainda pouco conhecido, fato atribuído em parte à escassez de informações científicas do processo (SROKA; TUSZYNSKI, 2007).

Segundo Pereira et al. (2009), a produção de mel é uma atividade com grande importância econômica em várias regiões de Portugal. No entanto, hoje em dia no nordeste de Portugal, há um excesso de mel que está sendo vendido abaixo do preço de produção, tornando-se necessário encontrar novas maneiras de tornar a apicultura viável, sendo uma possível solução para este problema a produção de hidromel.

Trindade et al. (2007) avaliaram a aceitação do sorvete com glicose de milho substituída por mel silvestre, como uma nova forma de introduzir o mel na alimentação. Além disso, os autores estudaram se houve alguma alteração na textura do sorvete produzido. O uso do mel como substituto da glicose de milho, não apresentou diferenças nos atributos relacionados ou efeito que a glicose exerce para a qualidade do sorvete. $\mathrm{O}$ sorvete mostrou-se com ótima aparência, bom rendimento, liga e maciez, além do valor nutricional agregado. $\mathrm{O}$ teste de aceitabilidade, realizado com 143 provadores, demonstrou que grande parte dos provadores julgou como "gostei muito" e "gostei muitíssimo" o que revela uma boa aceitação do produto.

A produção de aguardente de mel é apresentada como uma forma de otimizar o aproveitamento do mel que não se enquadra nos padrões exigidos pela legislação em vigor (SBRT, 2010).

\subsection{Destilados}

O Decreto $\mathrm{n}^{\circ} 6871$ do Ministério da Agrilcultura Pecuária e Abastecimento (MAPA), de 04/06/2009, define bebida alcoólica destilada como a bebida alcoólica obtida por processo de fermento-destilação, pelo rebaixamento do teor alcoólico de destilado 
alcoólico simples, pelo rebaixamento do teor alcoólico do álcool etílico potável de origem agrícola ou pela padronização da própria bebida alcoólica destilada (BRASIL, 2009).

Existem diversos tipos de bebidas destiladas, cada qual com suas caracerísticas individuais, e obtidas de vários tipos de matérias-primas.

Em Galiza, noroeste da Espanha, é produzida uma bebida destilada a partir do bagaço de uva fermentado, denominada "Orujo Gallego". Esta bebida é considerada um produto de alta qualidade, com uma grande importância para a economia desta tradicional região produtora de vinho (DIÉGUEZ; DE LA PENÃ; GÓMEZ, 2001).

Destilados semelhantes, obtidos a partir do bagaço de uva fermentado, também são produzidos em outros países, e recebem diversas denominações tais como: "tsipouro" na Grécia, "grappa”na Itália, “eau-de-vie de marc"na França, “aguardente"na Espanha, “bagaceira”em Portugal, entre outros (APOSTOLOPOULO et al., 2005).

De acordo com o Decreto 6871 do MAPA (BRASIL, 2009), Uísque, whisky ou whiskey é a bebida com graduação alcoólica de trinta e oito a cinqüenta e quatro por cento em volume, a vinte graus Celsius, obtida do destilado alcoólico simples de cereais envelhecido, parcial ou totalmente maltados, podendo ser adicionado de álcool etílico potável de origem agrícola, ou de destilado alcoólico simples de cereais, bem como de água para redução da graduação alcoólica e caramelo para correção da cor.

Em geral, um uísque pode ser caracterizado por três propriedades: o conteúdo de etanol (o uísque escocês deve apresentar o mínimo de $40 \% \mathrm{v} / \mathrm{v}$ ), o perfil congênere e a consistência de cor (McINTYRE et al., 2011).

Rum, rhum ou ron é a bebida com graduação alcoólica de trinta e cinco a cinqüenta e quatro por cento em volume, a vinte graus Celsius, obtida do destilado alcoólico simples de melaço, ou da mistura dos destilados de caldo de cana-de-açúcar e de melaço, envelhecidos total ou parcialmente, em recipiente de carvalho ou madeira equivalente, conservando suas características sensoriais peculiares (BRASIL, 2009).

Segundo Pino (2007), rum é a bebida obtida do destilado de melaço, após fermentação com levedura e posterior envelhecimento em barris de carvalho, onde o destilado adquire características especiais de sabor e aroma durante o tempo em que está em contato com a madeira. Durante a maturação o destilado extrai diversos compostos da madeira, os quais têm uma influência positiva sobre as características sensoriais do produto 
final. De acordo com o Decreto 6871, rum também pode ser obtido da mistura dos destilados de caldo de cana-de-açúcar e de melaço, envelhecidos total ou parcialmente, em recipiente de carvalho ou madeira equivalente, conservando suas características sensoriais peculiares (BRASIL, 2009).

No estado do Maranhão, dentre os derivados da mandioca, destaca-se a tiquira, destilado com alto teor alcoólico (36 a 54\%) produzido de forma artesanal, e bastante apreciado regionalmente (BRASIL, 2009; FURTADO et al., 2007). A tiquira é produzida e bastante apreciada, principalmente, nos estados do Maranhão e Piauí (SANTOS et al., 2005).

\subsubsection{Aguardente de Cana}

De acordo com a Legislação Brasileira, Instrução Normativa $n^{\circ} 13$ do Ministério da Agrilcultura Pecuária e Abastecimento (MAPA), de 29/06/2005, a denominação aguardente de cana se refere à bebida com graduação alcoólica de $38 \%$ vol a $54 \%$ vol, a $20^{\circ} \mathrm{C}$, obtida do destilado alcoólico simples de cana-de açúcar ou pela destilação do mosto fermentado do caldo de cana-de-açúcar, podendo ser adicionada de açúcares até $6 \mathrm{~g} / 1$, expressos em sacarose. Cachaça é a denominação típica e exclusiva da aguardente de cana produzida no Brasil, com graduação alcoólica de $38 \%$ vol a $48 \%$ vol a $20^{\circ} \mathrm{C}$, obtida pela destilação do mosto fermentado do caldo de cana-de-açúcar com características sensoriais peculiares, podendo ser adicionada de açúcares até $6 \mathrm{~g} / 1$, expressos em sacarose (BRASIL, 2005a).

De acordo com Florencio (2009), dados do Instituto Brasileiro da Cachaça (Ibrac) apontam que atualmente, os produtores nacionais somam mais de 40.000 , dando origem a cerca de 4.000 marcas. O setor é responsável pela geração de 600.000 empregos, diretos e indiretos, com capacidade instalada de produção de aproximadamente 1,2 bilhões de litros. Os maiores produtores de cachaça são: São Paulo (45\%), Pernambuco (12\%), Ceará (11\%), Rio de Janeiro (8\%), Minas Gerais (8\%), Goiás (8\%), Paraná (4\%), Paraíba (2\%) e Bahia (2\%) (SAKAI, 2010). Ainda segundo o Florencio (2009), o Ibrac também informa que em 2008 foram exportados 11,09 milhões de litros para cerca de 55 mercados, gerando uma receita de US\$16,41 milhões, o que permitiu um crescimento de $18 \%$ em valor e $20 \%$ em volume em relação a 2007. Porém, as exportações ainda representam uma fatia muito 
pequena do total do volume produzido anualmente com apenas $1 \%$ do mercado, sendo a Alemanha, Estados Unidos e França os principais países de destino da bebida.

Um grande esforço foi realizado para aumentar o volume de exportação e qualificar a cachaça internacionalmente como uma bebida típica do Brasil (CARDOSO et al, 2004). Importantes melhorias foram feitas no tocante ao conhecimento da composição química da cachaça na década passada (BOSCOLO et al., 2000; NASCIMENTO et al., 1999). Em consequência, o controle de qualidade foi melhorado, e sua composição química e perfil sensorial estão sendo elaborados (CARDOSO et al, 2004). No Brasil existem poucos estudos sobre a qualidade da aguardente de cana-de-açúcar, porém com as exigências do mercado externo, cresce a preocupação com a qualidade, principalmente devido à grande diversidade encontrada para este produto (PARAZZI et al., 2008).

É razoável supor que as características sensoriais da aguardente de cana, em especial o seu aroma, exercem um papel importante na preferência brasileira por esta bebida (NÓBREGA, 2003). Apesar da importância econômica e social da cachaça, são ainda escassos os estudos sobre sua qualidade sensorial, porém as crescentes exigências do mercado têm aumentado a preocupação com a qualidade dessa bebida (CARDELLO; FARIA, 1998; JANZANTTI, 2004).

A cadeia produtiva da aguardente no país não é tecnologicamente homogênea, havendo uma busca no desenvolvimento de tecnologias para aperfeiçoar e controlar a qualidade e a padronização da bebida (MIRANDA et al, 2007).

\subsubsection{Aguardente de Frutas}

O Decreto nº 6871 do Ministério da Agricultura Pecuária e Abastecimento (MAPA) define aguardente de frutas como a bebida com graduação alcoólica de 36 a $54{ }^{\circ} \mathrm{GL}$, a 20 ${ }^{\circ} \mathrm{C}$, obtida de destilado alcoólico simples de fruta ou pela destilação de mosto fermentado de fruta (BRASIL, 2009).

Este Decreto estabelece também que a aguardente de fruta terá a denominação da matéria-prima de sua origem e que poderá ter denominações diferenciadas como a aguardente de cereja, chamada de kirsch ou Dirchwassee; a aguardente de ameixa, como Slivowicz, Slibowika ou Mirabella; e a aguardente de maçã como Calvados. 
A destilação de fermentados de frutas tem sido utilizada em alguns países por muitos anos para obter bebidas saborosas com um teor elevado de álcool (HERNÁNDEZGÓMEZ et al., 2005).

Hernández-Gómez et al. (2005) realizaram a análise química e sensorial de diferentes destilados produzidos em planta piloto e compararam os resultados com os destilados obtidos em anos anteriores. Ao mesmo tempo, os compostos voláteis dos destilados obtidos foram comparados com os de outros destilados comercialmente disponíveis. Os autores utilizaram três diferentes substratos para a fermentação: suco de melão, polpa de melão sem pele (pws) e polpa de melão com pele (pasta). Os substratos foram inoculados com levedura comercial Saccharomyces cerevisiae e dois níveis de $\mathrm{pH}$ do caldo de fermentação foram testados. Avaliou-se o $\mathrm{pH}$ original dos substratos (6,0 para suco de melão, 5,9 para pws e 6,2 para pasta) e pH ajustado para 4,0 com adição de ácido cítrico. Os fermentados resultantes passaram por um processo de bidestilação. A análise química e sensorial mostrou que o $\mathrm{pH}$ da fermentação influenciou nas características do produto final produto final. Os destilados obtidos a partir da pasta de melão receberam avaliações negativas. No entanto, não foi observada nenhuma preferência entre os outros dois destilados. Os autores também verificaram que o $\mathrm{pH}$ da fermentação mostrou-se crítico para a produção de determinados compostos, como o acetato de etila e o lactato de etila, o que consequentemente contribuiu para os atributos sensoriais do produto final.

Verssini et al. (2009) utilizaram as técnicas de cromatografia gasosa acoplada ao detector de ionização de chamas (CG-FID) ou cromatografia gasosa acoplada à espectrometria de massa (CG-MS) para caracterizar os compostos responsáveis pelo aroma de destilados Italianos obtidos de maçãs nativas da Províncea de Sassari, região norte da Sardenha (variedades M. pumila, Miali e Appio) e compararam com alguns destilados obtidos a partir das principais variedades de maçãs cultivadas em outra região italiana, Trentino-Alto Adige (variedades M. pumila, Canadian Rennet, Golden Delicious, Royal Gala, Morgenduft e Gravenstein). Os destilados produzidos ao longo de quatro anos na Sardenha, foram obtidos do mesmo produtor, mantendo-se constante os processos de fermentação e preparação do mosto e o sistema de destilação descontínua. Os destilados de Trentino-Alto Adige foi obtido a partir de maçãs colhidas em um único ano, seguindo o mesmo processo de produção dos destilados da Sardenha. A análise dos compostos responsáveis pelo aroma dos destilados revelou que compostos como o octanoato de etila, 
2-metilbutirato hexila, 1-hexanol, benzaldeído e furfural, estão correlacionados com as variedades da maçã utilizada, sendo possível diferenciá-las entre si. Além disso, no caso dos destilados obtidos em Sardenha, foi verificado que alguns compostos como, 3-metil-1butanol, aldeídos totais, acetato de etila e 6-metil-5-hepten-2-ol, estão fortemente relacionados com o ano de produção.

Asquieri, Silva e Cândido (2009) produziram aguardente de jabuticaba a partir do subproduto da fabricação do fermentado de jabuticaba (casca e borra) e verificaram a sua qualidade mediante análises físico-químicas e posterior comparação aos padrões de aguardente de frutas existentes na legislação brasileira. O teor de ésteres encontrado foi de $357 \mathrm{mg} / 100 \mathrm{~mL}$, apresentando-se acima do estipulado pela legislação, que é de 250 $\mathrm{mg} / 100 \mathrm{~mL}$ de álcool anidro, sendo este valor elevado também em relação a outras aguardentes de frutas. Com respeito às outras variáveis, não foram encontrados valores discrepantes como, por exemplo, valores de grau alcoólico, densidade e acidez volátil, que foram de $39{ }^{\circ} \mathrm{GL}, 95 \mathrm{~cm}^{3} / \mathrm{g}$ e $30 \mathrm{mg} / 100 \mathrm{~mL}$ de $\mathrm{AA}$, respectivamente. Os autores concluiram que a aguardente é uma alternativa para produtores rurais que cultivam a jabuticaba evitando perdas pós-colheita consideráveis durante a safra.

Silva et al. (2009), avaliaram a qualidade físico-química e sensorial de aguardentes provenientes de mosto fermentado de polpa de banana e banana integral (polpa + casca) hidrolisadas enzimaticamente. A fermentação foi conduzida em dorna de aço inox por 72 horas à temperatura ambiente. Para o processo de destilação, foi utilizado alambique de cobre, com injeção direta de vapor e capacidade máxima para 50 litros. As aguardentes foram armazenadas por 10 dias em embalagens de vidro e fechadas com tampas metálicas, até o início das análises físico-químicas. Os resultados indicaram aumento para sólidos solúveis e açúcares redutores e diminuição para amido e celulose diante à hidrólise enzimática da polpa de banana e banana integral, com diferença significativa ao nível de $5 \%$ de probabilidade pelo teste t. Os resultados das análises físico-químicas e sensoriais indicaram qualidade similar entre as aguardentes de polpa de banana e banana integral.

Em estudo sobre a produção de aguardente de manga Tommy Atkins, Alvarenga, Maia e Oliveira (2006) utilizaram a enzima pectinolítica Allizin PP em concentração de $500 \mathrm{mg} / 1000 \mathrm{~g}$, para realizar um tratamento enzimático da polpa de modo a aumentar o rendimento da extração do suco e reduzir sua viscosidade. A hidrólise da polpa da manga 
foi realizada a $45^{\circ} \mathrm{C} / 40 \mathrm{~min}$. Após a hidrólise, a polpa foi fermentada com fermento comercial constituído de células de $S$. cerevisiae. O mosto fermentado foi destilado em alambique de cobre com capacidade de 5 litros e foram recolhidas separadamente as frações "cabeça", correspondente a 10\% do volume destilado e "coração". Na fração “coração" foram determinados o grau alcoólico, acidez titulável total, ésteres em acetato de etila, acetaldeído e álcoois superiores isoamílico isobutílico e n-propílico. A aguardente de manga produzida atendeu aos parâmetros físico-químicos da legislação vigente, com exceção do cobre. Os autores também realizaram a análise sensorial do destilado, aplicando-se o método afetivo por meio do teste de aceitação, utilizando-se escalas hedônicas de nove pontos. A bebida apresentou boa aceitação sensorial, com Índice de Aceitabilidade igual a $85,4 \%$ para o Aroma, $71,4 \%$ para o Sabor e $76,2 \%$ para a Impressão Global.

Munhoz et al. (2006) produziram e avaliaram sensorialmente a aguardente de mexerica ponkan (Citrus reticulata Blanco). Foi utilizada a levedura Saccharomyces cerevisae e o processo de fermentação ocorreu por três dias até o mosto atingir $4^{\circ}$ Brix. $\mathrm{O}$ fermentado obtido foi destilado em destilador de cobre com capacidade de 18 litros e destilado foi envasado em garrafas de vidro transparente. A aguardente foi avaliada sensorialmente quanto a sua aceitação global e ainda foram questionados os hábitos de consumo, a intenção de compra e as características mais e menos apreciadas pelos provadores. A característica mais apreciada citada por $48,78 \%$ dos provadores foi o aroma e a menos citada, $12,20 \%$ dos provadores, foi o sabor residual amargo. Os resultados demonstraram boa aceitabilidade para a formulação de aguardente de mexerica e os autores concluiram que é possível produzir a referida aguardente em escala comercial.

Segundo Silva Júnior et al. (2006) o Brasil é um dos maiores produtores mundiais de abacaxi (Ananás comosus L. Mervil), com mais de 700 mil toneladas anuais. Sendo assim, os autores estudaram as condições de processamento, na produção de um destilado de abacaxi, por meio da avaliação de algumas características físico-químicas da aguardente produzida em laboratório. Foi utilizado abacaxis da variedade pérola e o inóculo utilizado foi produzido a partir da mistura de quirera de milho, fubá de milho, fermento prensado e sulfato de amônio e magnésio, como nutrientes. Na destilação utilizou-se alambique de cobre com capacidade para 18 litros. A aguardente foi analisada quanto ao teor alcoólico, densidade, acidez total, volátil e fixa e os resultados mostraram que a aguardente produzida 
em pequena escala a partir de abacaxis atende aos padrões do MAPA e também aos padrões das bebidas comerciais, podendo ser uma alternativa para pequenos produtores.

\subsubsection{Outros Destilados}

Dragone et al. (2009) estudaram a produção e caracterização de uma nova bebida alcoólica por meio da fermentação descontínua do soro de queijo e posterior destilação do produto fermentado. Os autores utilizaram a levedura Kluyveromyces fragilis escolhida devido a sua capacidade de metabolizar lactose, com rápida taxa de crescimento e sem a produção de toxinas. Como resultado, os autores concluiram que é possível obter uma bebida destilada com características sensoriais agradáveis, a partir da fermentação de um mosto formulado com soro em pó, obtido de uma solução de soro de queijo com elevada concentração inicial de lactose (200 g/L). A análise dos principais compostos voláteis confirmou que a bebida cumpre com as exigências estabelecidas pela legislação européia para a produção de destilados.

\subsection{Produção de Aguardentes}

\subsubsection{Fermentação}

Fermentação é todo fenômeno causado por microrganismos vivos, sejam bactérias, fungos ou leveduras, que decompõe e transformam o substrato em produtos variados, e estes produtos resultantes dependem da composição do substrato e dos microrganismos presentes (JUSTINO; MUTTON; MUTTON, 2005).

Segundo Maia e Campelo (2006), durante a fermentação ocorre grande formação de gás carbônico, que é liberado para o ambiente. É comum a formação de espuma, principalmente nos estágios iniciais da fermentação, dada a interação do gás formado com lipídeos de características tensoativas, como os fosfolipídeos, e macromoléculas, especialmente proteínas, do mosto. Nas fermentações saudáveis, observa-se também o desenvolvimento progressivo de um aroma extremamente agradável, decorrente dos 
componentes secundários da fermentação, especialmente ésteres, como o acetato de etila e outros.

A fermentação alcoólica é um processo constituído basicamente por três etapas importantes: fermentação preliminar, onde ocorre a multiplicação das leveduras, devendo esta etapa ser curta para adapatação das mesmas ao meio; fermentação principal, onde se observa significativo desprendimento de $\mathrm{CO}_{2}$, com intensa produção de álcool e fermentação complementar, onde há o consumo dos açúcares que ainda estão disponíveis no meio (JUSTINO; MUTTON; MUTTON, 2005).

Segudo Janzantti (2004), a fermentação é a principal etapa do processo de produção de aguardente. Nesta etapa o açúcar e outros compostos presentes no mosto são transformados em etanol, $\mathrm{CO}_{2}$ e outros produtos que são responsáveis pela qualidade e defeito do produto. As fermentações são conduzidas em recipientes próprios denominados dornas e a escolha de uma levedura adequada à produção de aguadente vai depender basicamente da natureza do mosto, das condições industriais e das características desejáveis para o produto final.

O principal processo produtivo de aguardente é realizado em batelada e utiliza matérias-primas açucaradas, tais como melaço e caldo de cana, e como agente fermentador, a levedura Saccharomyces cerevisae, entretanto outros microrganismos também podem ser utilizados (DORNELLES; RODRIGUES, 2006).

Dornelles, Rodrigues e Garruti (2009), traçaram o perfil do destilado do caldo de cana fermentado com grânulos de Kefir por meio da análise descritiva comparando-o com o perfil de uma aguardente produzida com $S$. cerevisae e avaliaram a aceitabilidade do destilado obtido frente a um produto comercial líder de mercado. O estudo da aceitação da aguardente produzida com grânulos de Kefir mostrou que o seu grau de aceitação foi de $54,39 \%$, ou seja, menor do que o grau de aceitação da aguardente produzida com levedura S. cerevisae, que foi de $64,91 \%$, porém sua aceitação pelos consumidores foi maior que a da amostra comercial, a qual apresentou $29,82 \%$ de aprovação.

As leveduras utilizadas na produção de bebidas alcoólicas devem apresentar as seguintes características: alta tolerância ao álcool e bom rendimento; fermentar rapidamente o meio e, portanto, minimizar o risco de contaminações; produzir a melhor concentração e balanço de compostos secundários desejáveis para a qualidade da bebida. Devem ainda apresentar estabilidade genética e ao fim da fermentação, serem facilmente removidas do meio por floculação ou centrifugação (OLIVEIRA, 2001). 
A massa de células para se iniciar a fermentação denomina-se pé-de-cuba, pé-defermentação, lêvedo alcoólico ou fermento, e deverá estar ativa e em quantidade adequada, para que o processo ocorra de modo satisfatório (JUSTINO; MUTTON; MUTTON, 2005).

Saccharomyces cerevisiae é a espécie dominante (MORAIS et al., 1997), mas muitas leveduras que não são S. cerevisiae também tem sido isoladas durante o processo de fermentação (SCHWAN et al., 2001). Como conseqüência, as cachaças artesanais normalmente possuem qualidades sensoriais adicionais, devido aos metabólitos e aos compostos voláteis produzidos, únicos a cada espécie de levedura presente durante o processo de fermentação (NOVA et al., 2009).

A etapa de multiplicação celular das leveduras responsáveis pela fermentação alcoólica no caldo de cana depende da presença de compostos nitrogenados tais como proteínas e ácidos nucléicos, os quais são fundamentais à biossíntese da estrutura celular (POLASTRO et al, 2001). Compostos nitrogenados são importantes para o metabolismo das leveduras. O conteúdo inicial de nitrogênio total do mosto e as concentrações relativas de cada um dos constituintes nitrogenados afetam o crescimento das leveduras, a velocidade de fermentação e a formação do produto final (BELL; OUGH; KLIEWER, 1979; DUTRA; DAUDT; SOUZA, 1999). A concentração de nitrogênio total em mostos é muito variável e dependente da espécie vegetal que se utiliza para a fermentação, da região produtora e das condições do solo (HENSCHKE; OUGH, 1991).

\subsubsection{Destilação}

A destilação é o processo de volatilizar líquidos pelo aquecimento, condensando-os a seguir, objetivando especialmente a purificação e concentração, ou formação de produtos novos por decomposição das frações (JUSTINO; MUTTON, MUTTON, 2005).

Após a fermentação, o mosto de cana passa a ser chamado vinho, compõe-se de água e álcool etílico em maiores proporções, e muitos outros compostos que constituem a chamada "fração não álcool", ou também denominada "componentes secundários", substâncias essas responsáveis pelo sabor e aroma das aguardentes (BIZELLI; RIBEIRO; NOVAES, 2000). Os principais componentes da fração não álcool são: aldeído acético, ácido acético e ésteres desses ácidos, furfural e álcoois superiores como o amílico, 
isoamílico, butílico, isobutílico, propílico e isopropílico (LIMA; BASSO; AMORIN, 2001).

O processo de destilação do vinho, que contêm um grande número de compostos voláteis, ocorre segundo três critérios: ponto de ebulição, afinidade com o álcool ou água e teor alcoólico no vapor durante a destilação (LÉAUTÉ, 1990).

Segundo Bizelli, Ribeiro e Novaes (2000), os componentes voláteis do vinho possuem diferentes graus de volatilidade, sendo possível a separação por processo de destilação. Assim, os componentes mais voláteis são recolhidos na primeira fração do destilado denominado de "cabeça", e os menos voláteis nas frações finais, "cauda". A porção intermediária é conhecida como “coração" e é constituída principalmente de frações medianamente voláteis.

De acordo com Janzantti (2004), as bebidas fermento-destiladas têm como principal característica o teor alcoólico superior ao de bebidas fermentadas. $\mathrm{O}$ autor também relata que, além do etanol, outros compostos secundários estão presentes e são os principais responsáveis pelas características sensoriais destas bebidas. São esses compostos secundários, também denominados compostos voláteis ou congêneres, que diferenciam e definem as características das diversas bebidas fermento-destiladas, sendo portanto, os determinantes de sua qualidade. Os álcoois superiores são quantitativamente o maior grupo de compostos responsáveis pelo aroma em todos os destilados (DIÉGUEZ; DE LA PEÑA; GÓMEZ, 2001).

A otimização das condições da operação de destilação é fundamental na obtenção de bebida de boa qualidade, pois, a destilação além de separar, selecionar e concentrar pelo uso do calor os componentes do vinho ainda promove algumas reações químicas induzidas pelo calor (BOZA; HORII, 1998).

A Instrução Normativa número 13, de 30 de Junho de 2005, estabelece que a destilação deve ser efetuada de forma que o produto obtido preserve o aroma e o sabor dos principais componentes contidos na matéria-prima e daqueles formados durante a fermentação. Além disso, é vedada a adição de qualquer substância ou ingrediente após a fermentação ou introduzido no equipamento de destilação que altere as características sensoriais naturais do produto (BRASIL, 2005a). 


\subsubsection{Envelhecimento}

No Brasil, a etapa de envelhecimento da aguardente é optativa, não sendo realizada sistematicamente devido ao tempo requerido pelo processo e aos custos introduzidos pelo armazenamento da bebida em tonéis por alguns anos (MIRANDA et al, 2008). A grande maioria das aguardentes brasileiras, não é envelhecida como as demais bebidas destiladas, consideradas nobres e que disputam o mercado internacional (PADOVAN; BORRAGINI; FARIA, 2004).

A madeira tradicionalmente utilizada na manufatura dos tonéis para $o$ envelhecimento de bebidas destiladas é o carvalho (JANZANTTI, 2004). As reações que ocorrem durante o envelhecimento favorecem a formação de compostos que influenciam a cor, o odor e o sabor das bebidas destiladas (PARAZZI et al, 2008).

Geralmente, a bebida envelhecida apresenta menor teor alcoólico e maior concentração de compostos fenólicos e ésteres, características responsáveis pela melhoria em sua aceitação (MOSEDALE; PUECH, 1998). Desta forma, é de extrema importância o período de envelhecimento da aguardente, onde ocorrem reações como oxidação e esterificação, que reduzem a concentração alcoólica e tornam o produto do ponto de vista sensorial, significativamente melhor (CARDELLO; FARIA, 1998).

Segundo Mosedale e Puech (1998), a mudança nas características sensoriais da bebida envelhecida se deve a alterações na composição e na concentração dos seus compostos, as quais são causadas por extração direta dos compostos da madeira; quebra das macromoléculas da madeira e extração dos seus produtos para o destilado; reações entre os compostos do destilado e da madeira; reação entre os próprios extrativos da madeira; reação entre os próprios componentes do destilado; e evaporação dos compostos voláteis.

A qualidade da bebida envelhecida depende do tipo de madeira empregada, tempo de envelhecimento, qualidade inicial e teor alcoólico do destilado, bem como da temperatura e a umidade relativa do ambiente de envelhecimento (SINGLETON, 1995).

O tempo necessário para o envelhecimento satisfatório varia de acordo com as características da matéria-prima utilizada na elaboração do mosto, o tamanho do barril, a origem da madeira e o tratamento do barril e do ambiente em que a aguardente está sendo envelhecida (MOSEDALE; PUECH, 1998).

Cardello e Faria (1998) utilizaram a análise descritiva quantitativa, metodologia muito aplicada na caracterização dos atributos sensoriais de alimentos e bebidas, para 
estudar o perfil sensorial da aguardente de cana, durante o envelhecimento, em toneis de carvalho. Foram analisadas amostras de aguardente envelhecidas durante 0, 12, 24, 36 e 48 meses em um tonel de carvalho de 200 litros e duas amostras comerciais, sendo uma delas envelhecida. Os autores verificaram que as características sensoriais das amostras mudaram significativamente $(\mathrm{p} \leq 0,05)$ com o aumento do tempo de envelhecimento. $\mathrm{O}$ produto após 48 meses de envelhecimento apresentou aroma de madeira, doçura inicial e residual, aroma de baunilha, coloração amarela, gosto inicial e residual de madeira pronunciados. Por outro lado, o aroma alcoólico, a agressividade e os sabores inicial e residual de álcool, foram significativamente inferiores em relação às demais amostras. Portanto, os autores concluiram que o envelhecimento da aguardente em tonel de carvalho proporciona a obtenção de uma bebida de característica sensorial superior.

No Brasil existem poucos estudos sobre a qualidade da aguardente de cana-deaçúcar, porém com as exigências do mercado externo, cresce a preocupação com a qualidade, principalmente devido à grande diversidade encontrada para este produto (PARAZZI et al., 2008).

Considerando o exposto acima, Parazzi et al. (2008) estudaram as principais alterações na composição química da aguardente envelhecida, em função do tempo de armazenamento. As amostras de aguardentes foram armazenadas em barris de carvalho e em recipientes de vidro, sob as mesmas condições. As amostragens para análises foram realizadas a cada três meses por um período de três anos e foram determinados os seguintes compostos: teor alcoólico, polifenóis, acetaldeído, acetato de etila, metanol, nbutílico, n-propílico, isobutílico, isoamílico, acidez e cobre. Comparando as diferentes épocas de amostragem, os autores verificaram que as aguardentes armazenadas em barris de madeira apresentaram diferenças significativas, ao nível de 95\% de probabilidade, para todos os elementos analisados, com exceção do n-butílico. As aguardentes armazenadas em recipientes de vidro não apresentaram diferenças significativas quanto às épocas de amostragem, ou seja, os teores dos elementos analisados não variaram, considerando o período de envelhecimento, com exceção da concentração de acetato de etila.

O grau alcoólico de uma aguardente armazenada em tonéis de madeira pode sofrer oscilações em função da umidade relativa e da temperatura ambiente (MIRANDA et al., 2008).

De acordo com Singleton (1995) ocorre perda de aproximadamente $2 \%$ a $7 \%$ do volume da aguardente armazenada em tonéis, por ano de envelhecimento, dependendo do tamanho do recipiente, temperatura, umidade relativa e circulação de ar ao redor do barril. 
A umidade relativa tem um menor efeito do que a temperatura ambiente, porém para uma determinada temperatura, uma alta umidade relativa diminui a taxa de perda de água e, para temperaturas mais elevadas e maior circulação externa de ar, a perda de volume pode aumentar. Também ocorre perda de etanol por difusão através da madeira ou por evaporação. Em ambiente de baixa umidade relativa, a perda de água é favorecida, enquanto que a alta umidade favorece a perda de álcool através dos tonéis.

O aumento da acidez volátil da aguardente, durante o período de envelhecimento, se deve à reação de oxidação do etanol, a qual contribui para a formação de acetaldeído, o qual, por sua vez, conduz à formação de ácido acético (REAZIN, 1981; LITCHEV, 1989). Além disso, alguns compostos oriundos da madeira, tais como ácidos orgânicos não voláteis, componentes secundários, taninos e compostos fenólicos, favorecem o aumento da acidez da aguardente em envelhecimento (MIRANDA et al., 2008).

Miranda et al. (2008) avaliaram por um período de 390 dias o perfil da composição química da aguardente de cana sob envelhecimento em tonéis de carvalho de $20 \mathrm{~L}$ e verificaram que após 390 dias de armazenamento, a aguardente apresentou maiores concentrações de acidez volátil, ésteres, aldeídos, furfural, álcoois superiores, congêneres, extrato seco e tanino. Sua coloração tornou-se amarelada. As concentrações de etanol e de metanol não se alteraram, e o teor de cobre apresentou ligeiro declínio. O envelhecimento da aguardente por 390 dias em tonéis de carvalho alterou a sua composição química, porém se manteve dentro dos padrões de qualidade estabelecidos pela legislação nacional em vigor.

Miranda, Horii e Alcarde (2006) estudaram o efeito da irradiação gamma $\left({ }^{60} \mathrm{CO}\right)$ na qualidade da cachaça e no tonel de envelhecimento, pois de acordo com os autores, a irradiação pode acelerar o processo de envelhecimento. Amostras de cachaça com aproximadamente $43{ }^{\circ} \mathrm{GL}$ foram submetidas a dois tratamentos: com e sem irradiação. Esses tratamentos foram divididos em dois subtratamentos: com e sem contato com a madeira. O tratamento com irradiação $(150 \mathrm{~Gy})$ foi ainda subdividido em: irradiação da cachaça e posterior introdução no tonel; irradiação do tonel e posterior introdução da cachaça; e introdução da cachaça no tonel e irradiação do conjunto (tonel e cachaça). Foram utilizados tonéis de carvalho de $20 \mathrm{~L}$ de capacidade. Análises físico-químicas e cromatográficas foram realizadas periodicamente ao longo de 390 dias do período de envelhecimento da bebida. Os autores concluiram que a irradiação da cachaça e do tonel não alterou a maioria dos componentes voláteis do coeficiente de congêneres como acidez volátil, ésteres, álcoois superiores e furfural durante os 390 dias. No entanto, os mesmos 
relatam que há evidências, entretanto, de que os parâmetros de alguns componentes como aldeídos, taninos, cor e teor de cobre são de alguma forma influenciados, resultando em aceleração parcial do processo de maturação ou envelhecimento. Ao final do período de envelhecimento, foi feita uma análise sensorial com 30 provadores não treinados. A aceleração do processo de envelhecimento foi confirmada pela avaliação sensorial, e a cachaça e/ou tonel irradiados receberam maior indicação de aprovação em todos os parâmetros analisados (aroma, sabor e aparência).

\subsection{Fatores que Interferem na Qualidade do Destilado}

Segundo Miranda et al. (2007), o aprimoramento da qualidade e da padronização da aguardente e da cachaça é essencial para que a bebida atenda aos padrões internacionais e seja aceita pelo mercado externo, proporcionando condições de abertura e manutenção do mercado de exportação. Além disso, proporcionaria melhor aceitação no mercado interno pelas classes de maior poder aquisitivo, as quais exigem bebida de boa qualidade.

Os padrões de identidade e qualidade para aguardente de cana e para cachaça estão apresentados na Tabela 14, no Anexo A, e são fixados pela Instrução Normativa $n^{\circ} 13$, de 29/06/2005, de responsabilidade do Ministério da Agricultura, Pecuária e Abastecimento (MAPA) (BRASIL, 2005a). Também, de acordo com esta Instrução Normativa, deverão ser detectadas as presenças de compostos fenólicos totais nas Aguardentes de Cana e nas Cachaças envelhecidas.

Para as aguardentes de frutas, o MAPA fixa os parâmetros de identidade e qualidade segundo Portaria $n^{\circ}$ 65, de 23/04/2008 (BRASIL, 2008). Estes parâmetros estão apresentados na Tabela 15, do Anexo A.

A presença de cobre nas bebidas destiladas tem sido um dos problemas intrínsecos à sua produção, pois, desde o início da produção de bebidas fermento-destiladas, o cobre é o material mais extensivamente utilizado nas construções de alambiques devido às inúmeras vantagens que apresenta como resistência à corrosão, boa condução de calor, além de reagir com alguns componentes do vinho e atuar como catalisador, em reações altamente favoráveis às características sensoriais da bebida (LÉAUTÉ, 1990).

Bizelli, Ribeiro e Novaes (2000) avaliaram a influência da condução da destilação sobre os teores de acidez e de cobre da aguardente de cana. Duas técnicas de destilação em 
alambiques simples foram confrontadas, a destilação convencional e a bidestilação. A bidestilação permitiu a redução dos teores de cobre e acidez total no produto.

Nas aguardentes, o cobre aparece com freqüência, principalmente nas destiladas em alambique de cobre (JANZANTTI, 2004). As indústrias de bebida não encontram barreira fiscal para o excesso de cobre ao nível do mercado interno, pois no Brasil é permitido atualmente um limite máximo de $5 \mathrm{mg} / \mathrm{L}$ tanto para aguardente de cana (BRASIL, 2005a) como para aguardente de fruta (BRASIL, 2008), porém, o mesmo não ocorre quando se trata do mercado internacional, pois vários países, possíveis importadores, não admitem a presença deste metal na bebida (FARIA; POURCHET-CAMPOS, 1989).

Quando a aguardente é fermentada e destilada em recipientes constituídos de outros materiais, como o aço inox, o produto final contém compostos sulfurados, sendo a bebida resultante de baixa qualidade sensorial (ALVES; CARDELLO; FARIA, 2002; ISIQUE; CARDELLO; FARIA, 1998). Porém, a presença de cobre na aguardente em elevadas concentrações é indesejável, pois é prejudicial à saúde humana, sendo, portanto, fundamental sua quantificação (AZEVEDO et al., 2003).

Alves, Cardello e Faria (2002) ao estudarem a origem dos compostos sulfurados presentes na cachaça, concluiram que pelo menos parte dos compostos sulfurados presentes nas aguardentes de cana tem origem nas estruturas proteicas das leveduras e são formados durante a destilação da bebida. Além disso, concluiram que a centrifugação do vinho representa uma opção tecnológica válida para reduzir os teores de enxofre presentes nas aguardentes de cana e, assim, melhorar sua qualidade sensorial.

A presença do metanol é indesejável na aguardente, pelas características de toxidade, mesmo em baixas concentrações e a origem deste álcool está associada à degradação da pectina (PARAZZI, 2008). A pectina é um composto formado pela associação de centenas de moléculas de ácido galacturônico, que possuem fragmentos de moléculas de metanol, as quais são liberadas durante o processo de fermentação (SILVA; PORTELA; ARAÚJO, 2007).

O conhecimento do perfil inorgânico da cachaça é importante para o controle das concentrações de metais pesados na mesma, contribuindo assim para a melhoria da qualidade da bebida. Além disso, estes dados poderiam ser úteis para classificar as cachaças de acordo com sua região geográfica de origem e sua adequação para o consumo do ponto de vista da saúde (NASCIMENTO et al., 1999).

Diéguez, De La Penã e Gómez (2001), estudaram a influência das condições de estocagem do bagaço de uva, na qualidade do destilado obtido a partir deste bagaço. Os 
autores analisaram a concentração de voláteis para estabelecer as condições ideais para o armazenamento e fermentação do bagaço e concluiram que, os recipientes mais adequados para o armazenamento do bagaço de uva são aqueles que permitem pouco ou nenhum contato do bagaço com o ar, como sacos plásticos ou recipientes de plásticos e que sejam pequenos suficiente para evitar altas temperaturas durante a fermentação alcoólica. Ao analisarem a influência do tempo de estocagem, os autores verificaram que o destilado obtido após 5 meses de estocagem do bagaço de uva, apresentou teores de metanol, acetato de etila, ácido butírico, álcoois superiores e estéres superiores aos do destilado obtido imediatamente após a fermentação do bagaço, concluindo desta maneira que o tempo de armazenamento é um fator determinante na qualidade do produto. 


\section{MATERIAL E MÉTODOS}

O presente trabalho foi desenvolvido nos Laboratórios do Departamento de Biotecnologia da Escola de Engenharia de Lorena (EEL - USP) e junto às intalações do Alambique da Associação Rural de Canas, Canas-SP.

\subsection{Matéria-prima}

Para a produção da aguardente de mel, foi utilizado mel de abelha, tipo silvestre, obtido de produtores da Região do Vale do Paraíba acondicionados em baldes de $20 \mathrm{~L}$ e armazenados a temperatura ambiente.

\subsection{Microrganismos}

\subsubsection{Isolamento das Leveduras}

As cepas de leveduras utilizadas neste estudo foram isoladas de frutas e de mel. As frutas utilizadas incluem abacaxi (Ananas comosus), mexerica (Citrus reticulata), uva (Vittis sp.) e acerola (Malpighia glabra) obtidas no comércio local. Para o isolamento das leveduras a partir de mel, foram utilizados mel não centrifugado e resíduo do processamento de mel após a etapa de sedimentação (borra do mel).

Fragmentos das respectivas frutas em estado maduro, porções de mel não centrifugado e borra de mel obtida após a etapa de sedimentação, foram transferidos assepticamente para tubos de ensaio contendo caldo YEPD-Cloranfenicol (Extrato de levedura $1 \%$, Peptona $2 \%$, Glicose $2 \%$, Cloranfenicol $0,1 \mathrm{~g} / \mathrm{L}$ ) previamente esterilizado a $121{ }^{\circ} \mathrm{C}$ por 20 min. e incubados a $30{ }^{\circ} \mathrm{C}$, até observação de crescimento celular, pelo aumento da turbidez do meio. Em seguida estas células foram propagadas por meio de repicagens sucessivas, em caldo YEPmel-Cloranfenicol contendo concentrações de mel progressivamente crescentes $\left(2,5,10,15,20,25\right.$ e 30\%) em substituição a glicose, a $30^{\circ} \mathrm{C}$ / 24 horas. Após atingir o crescimento satisfatório em caldo YEPmel contendo $30 \%$ de mel, uma alçada da respectiva suspensão celular foi transferida para placas contendo agar 
YEPmel 30 que foram incubadas a $30^{\circ} \mathrm{C}$ por $24-48$ horas de forma a se obter colônias isoladas. As colônias devidamente isoladas foram transferidas para tubos de ensaio contendo ágar inclinado YEPmel 30, incubados a $30{ }^{\circ} \mathrm{C}$, por $24-48$ horas, após o que foram mantidas sob refrigeração a $4^{\circ} \mathrm{C}$ e posteriormente avaliadas.

Os isolados de leveduras que apresentaram desempenho fermentativo satisfatório foram devidamente identificados junto ao Departamento de Biologia da Universidade Federal de Lavras - MG.

As características fenotípicas dos respectivos isolados foram determinadas por sua morfologia e formação de esporos, bem como sua assimilação e fermentação de diferentes fontes de carbono e, os isolados de levedura também foram identificados por técnica de PCR utilizando primers para duas regiões distintas do RNAr das regiões ITS e 18S do ribossomo das mesmas, sendo o sequenciamento realizado pela MACROGEN, Coréia do Sul (MAGALHÃES et al., 2010).

\subsubsection{Preparo do Inóculo}

Inicialmente as células de levedura devidamente isoladas e armazenadas em Ágar inclinado foram ativadas por meio de repicagens sucessivas em caldo YEPMel contendo concentrações de mel progressivamente crescentes $(5 \%, 10 \%$ e $15 \%$ de mel) e incubadas a $30^{\circ} \mathrm{C}$ por $24-48$ horas, em incubadora com movimento rotatório sob agitação de $200 \mathrm{rpm}$. As repicagens foram realizadas em frascos Erlenmeyer de $50 \mathrm{~mL}$ contendo $10 \mathrm{~mL}$ de meio e alíquotas de $0,5 \mathrm{~mL}(5 \%)$ foram transferidas de um frasco para outro. Após atingir o crescimento satisfatório em caldo YEPMel-15, foi realizada a contagem de células em camâra de Neubauer de modo a se verificar o volume adequado a ser utilizado como inóculo na fermentação, para se obter inicialmente uma quantidade de células na ordem de $10^{7}$ células por $\mathrm{mL}$. Para as leveduras floculantes, o inóculo utilizado correspondeu a $1 \%$ do volume de meio.

\subsection{Avaliação do Meio e Condições de Fermentação}

Em uma primeira etapa os respectivos isolados foram avaliados quanto ao desempenho fermentativo em mosto constituído de Mel $15{ }^{\circ}$ Brix suplementado, 
individualmente, com diferentes nutrientes, a saber: extrato de levedura comercial $(10,0$ $\mathrm{g} / \mathrm{L}$ ), extrato de farelo de arroz (equivalente a 20,0 g/L), mistura $(1,0 \mathrm{~g} / \mathrm{L})$ constituída de farelos de milho, arroz e soja na proporção 5:2:5 e nutriente comercial (D\&R alambiques, Belo Horizonte - MG) $(0,15 \mathrm{~g} / \mathrm{L})$. O pH do meio de fermentação foi corrigido para 4,5 com $\mathrm{H}_{2} \mathrm{SO}_{4} 0,5 \mathrm{~N}$, e as fermentações foram realizadas em duplicata.

Como controle, avaliou-se o meio de fermentação composto apenas de mel $15^{\circ} \mathrm{Brix}$ sem suplementação.

Para a utilização do farelo de arroz como nutriente, foi preparado um extrato obtido a partir de $200 \mathrm{~g}$ de farelo suspendido em 1 L de água destilada, o qual foi autoclavado por $15 \mathrm{~min}$ a $0,5 \mathrm{~atm}$. Após o resfriamento, esta suspensão foi centrifugada em condições assépticas a 2000 x g por 30 min. A fração líquida (extrato de farelo de arroz) foi transferida para um frasco previamente esterilizado e conservada a $4{ }^{\circ} \mathrm{C}$ até a sua utilização, num prazo máximo de uma semana após o seu preparo.

$\mathrm{O}$ meio de fermentação sem o mel foi autoclavado a $0,5 \mathrm{~atm}, 11{ }^{\circ} \mathrm{C}$, por 15 minutos. O mel foi pasteurizado a $75^{\circ} \mathrm{C} / 15$ minutos (TURHAN et al., 2008), de modo a evitar a formação de hidroximetilfurfural e em seguida foi utilizado na formulação, sob condições assépticas, dos respectivos meios de fermentação.

As fermentações foram conduzidas em tubos de ensaio, contendo $5 \mathrm{~mL}$ dos respectivos meios de fermentação, incubados em estufa a $30^{\circ} \mathrm{C}$ e amostras foram coletadas nos tempos $0,12,18,24$ e 36 horas e caracterizadas quanto a concentração de substrato, etanol e massa celular, o que permitiu a determinação do rendimento, eficiência e produtividade do processo.

Com este procedimento foi possível a identificação dos melhores isolados, bem como do meio de fermentação, os quais foram avaliados em escala piloto.

\subsection{Produção da Aguardente de Mel em Escala Piloto}

As condições de fermentação previamente determinadas na etapa anterior, bem como o isolado que apresentou melhor desempenho fermentativo, foram avaliados em processo de produção de aguardente de mel em escala piloto junto às instalações do Alambique da Associação Rural de Canas, Canas-SP.

O inóculo foi inicialmente preparado no laboratório (aproximadamento $2 \mathrm{~L}$ ), e posteriormente foi propagado até volume total de $80 \mathrm{~L}$, em tanque de inox de $350 \mathrm{~L}$, 
provido de sistema de aeração com chuveiro. O volume de mosto preparado para cada batelada correspondeu a $300 \mathrm{~L}$ sendo empregado o inóculo da carga anterior.

Foi utilizado extrato de levedura comercial na concentração de 5,0 g/L, como suplemento no meio. O mesmo, foi gentilmente cedido pela empresa Biorigin.

As fermentações foram conduzidas em caixas de PVC de $500 \mathrm{~L}$ de capacidade a temperatura ambiente e amostras foram coletadas periodicamente para se determinar o desempenho da fermentação, por meio da determinação da acidez do mosto e do vinho; ${ }^{\circ}$ Brix do mosto e do vinho; teor alcoólico do vinho e do destilado.

$\mathrm{O}$ vinho obtido foi submetido à destilação fracionada em dois alambiques de cobre de capacidade útil de $150 \mathrm{~L}$ cada, aquecidos por fogo indireto e equipados com dispositivo para resfriamento do capelo (Figuras 1 e 2). A fração "cabeça" foi cortada quando na saída atingiu aproximadamente $66{ }^{\circ} \mathrm{GL}$ e o destilado correspondente a fração "coração" foi cortado quando o destilado recolhido atingiu em torno de $44{ }^{\circ} \mathrm{GL}$, sendo a fração "cauda" descartada. Os volumes obtidos das frações "cabeça" e "coração" para cada batelada, com os seus respectivos teores alcoólicos foram devidamente determinados (Apêndice A).

A fração "coração" foi caracterizada físico-quimicamente e armazenada em tonel de carvalho de 200 L durante 6 meses. Os procedimentos de fermentação e destilação foram repetidos até se atingir o volume de destilado suficiente para completar o volume de 200 L, considerando esse momento como o tempo inicial.

Posteriormente, a cada 30 dias amostras foram coletadas e tiveram suas características sensoriais e físico-químicas avaliadas em conformidade com os padrões estabelecidos pela legislação brasileira (BRASIL, 2008). 


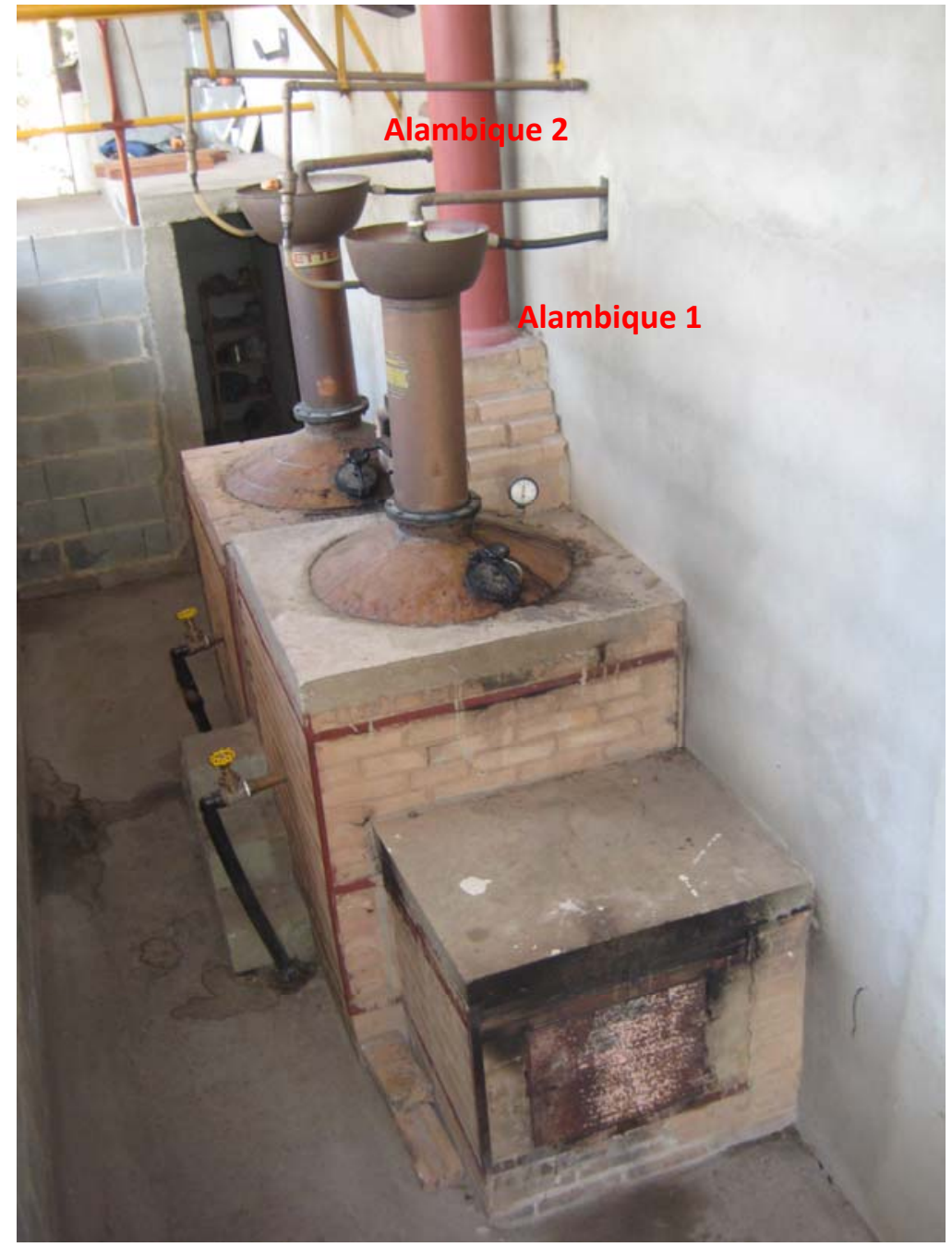

Figura 1 - Alambiques utilizados na produção da aguardente de mel.

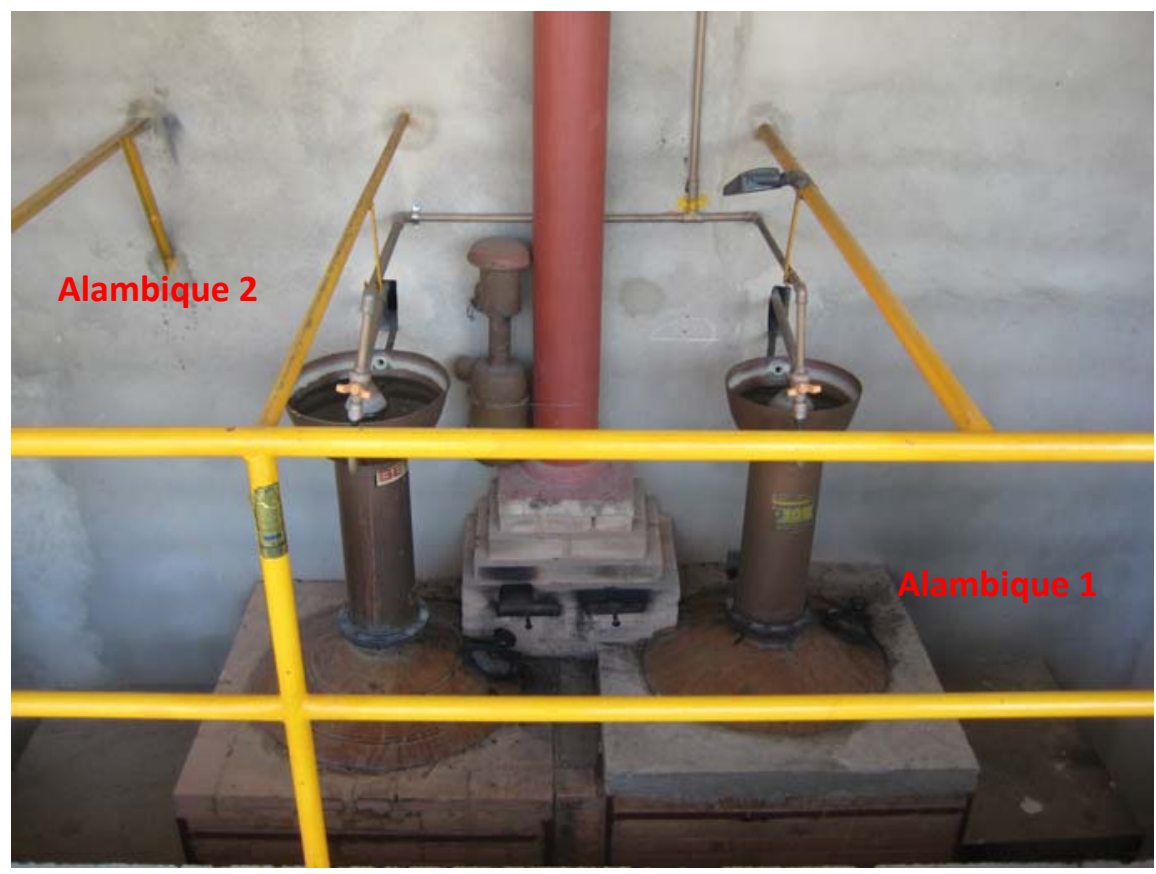

Figura 2 - Vista superior dos alambiques utilizados na produção da aguardente de mel. 


\subsubsection{Avaliação Fisico-química}

As respectivas amostras foram deviamente caracterizadas quanto a: Densidade Relativa, Cobre, Extrato Seco a $100^{\circ} \mathrm{C}$, Grau Alcoólico Real a $20^{\circ} \mathrm{C}$, Acidez Volátil em Ácido Acético, Álcoois Superiores, Furfural, Aldeídos em Aldeído Acético, Ésteres em Acetato de Etila, Soma dos Componentes Secundários e Álcool Metílico. Para tanto, as amostras foram enviadas ao Laboratório de Análise de Bebidas da Universidade Federal de Lavras, onde foi utilizado para as análises o método descrito em MAPA/DAS/CGAL Manual de Métodos de Análises de Bebidas e Vinagres (BRASIL, 2005b).

\subsubsection{Avaliação Sensorial}

A avaliação sensorial da aguardente de mel foi realizada nas instalações do Laboratório de Análise Sensorial da Planta Piloto de Bebidas do Departamento de Biotecnologia da EEL. Para tanto as amostras foram submetidas a teste de aceitação (FRANCO; FROTA; FARIA, 2009) considerando os quesitos aparência, aroma, sabor, corpo e impressão global, além da atitude de compra. Para tanto, foram recrutados entre alunos, professores e funcionários da EEL, 120 julgadores, maiores de 18 anos. As amostras foram apresentadas aos julgadores em cabines individuais, de forma monádica e codificadas com algarismos de três dígitos, em taças de plástico transparente. Os julgadores avaliaram as amostras de aguardente de mel preenchendo uma ficha conforme apresentado a seguir, onde se observa uma escala hedônica não estruturada de 9 pontos, cujos resultados foram então submetidos à ANOVA e teste de Tukey (SAS, 2001). 


\section{Ficha de avaliação do teste de aceitação.}

Nome:

Sexo: ( ) Feminno ( ) Masculino

Faixa etária: ( ) $18-25$ anos ( ) $26-35$ anos ( ) $36-45$ anos

( ) $46-55$ anos ( ) $56-65$ anos ( ) $66-75$ anos

Freqüência com que consome bebida alcoólica:

( ) diariamente ( ) semanalmente ( ) mensalmente ( ) eventualmente

No. da Amostra

Você está recebendo uma amostra de Aguardente de Mel.

Por favor, observe, aspire e prove a amostra e marque na escala o que você achou:

Em relação à aparência:

Desgostei extremamente

Gostei extremamente

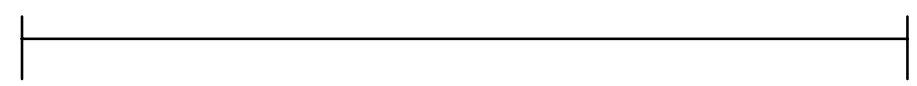

Em relação ao aroma:

Desgostei extremamente

Gostei extremamente

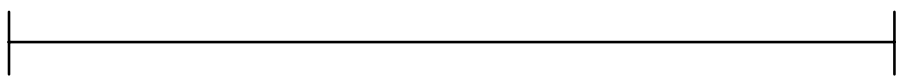

Em relação ao sabor:

Desgostei extremamente

Gostei extremamente

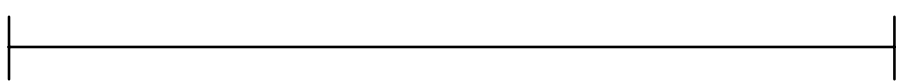

Em relação ao corpo:

Desgostei extremamente

Gostei extremamente

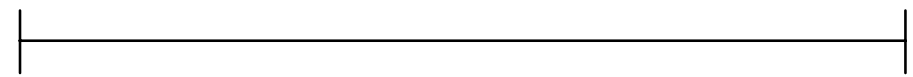

Em relação à impressão global:

Desgostei extremamente

Gostei extremamente

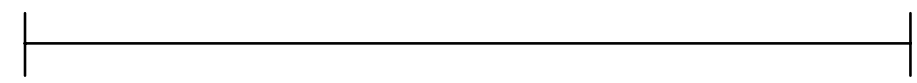

O que você mais gostou nessa amostra?

$\mathrm{O}$ que você menos gostou nessa amostra?

Justifique:

Comentários:

Se este produto estivesse à venda nos mercados, qual seria sua atitude?

( ) Eu certamente não compraria

( ) Eu provavelmente não compraria

( ) Eu tenho dúvida se compraria ou não

( ) Eu provavelmente compraria

( ) Eu certamente compraria

Com que freqüência você consumiria este produto:

( ) Diariamente,

( ) Semanalmente,

( ) Mensalmente

( ) Eventualmente 
Os dados da análise sensorial de aceitação em relação à aceitação global foram analisados também por análise estatística multivariada (Mapa de Preferência Interno), segundo metodologia descrita por Macfie e Thomson (1988) realizada utilizando-se o Programa MDPREF do PC-MDS Multidimensional Statistic Package (SMITH, 1990).

Também foi realizada a Análise Hierárquica de Grupos (Hierarchical Clusters Analysis, HCA) (MOITA NETO; MOITA, 1998), que consiste de uma técnica estatística multivariada, a qual tem como principal objetivo, unir objetos (amostras), em grupos homogêneos de acordo com suas semelhanças (SERAFIN, 2010). Para tanto, foi utilizado o programa MINITAB Statistical Software ${ }^{\circledR}$ versão 14 (MINITAB, 2006).

\subsection{Métodos Analíticos}

\subsubsection{Determinação do $\mathrm{pH}$}

Os valores de $\mathrm{pH}$ das amostras foram determinados em pHmetro Digital PG1800, marca Gehaka.

\subsubsection{Determinação da acidez}

A acidez do mosto e do vinho foi determinada por titulação de $20 \mathrm{~mL}$ da amostra com uma solução de $\mathrm{NaOH}$ 0,5 M empregando 5 gotas de fenolftaleína $1 \%$ como indicador, e foi expressa em acidez sulfúrica $(\mathrm{g} / \mathrm{L})$.

A acidez da aguardente de mel foi determinada por titulação de $50 \mathrm{~mL}$ da amostra com uma solução de $\mathrm{NaOH} \quad 0,05 \mathrm{M}$ empregando 5 gotas de fenolftaleína $1 \%$ como indicador e foi expressa em $\mathrm{mg}$ de ácido acético/100 $\mathrm{mL}$ de álcool anidro. 


\subsubsection{Contagem Celular}

A contagem de células foi realizada em câmara de Neubauer e está expressa em número de células por $\mathrm{mL}$. As observações foram realizadas em microscópio ótico Opton modelo TNB-04T-PL;

Para a contagem de células das leveduras floculantes, utilizou-se uma solução desfloculante para ressuspender as mesmas, conforme metodologia adaptada de Domingues (2001), na qual o autor utiliza uma solução salina de $15 \mathrm{~g} / \mathrm{L}$ de $\mathrm{NaCl}$ em pH 3,0. No presente trabalho foi utilizada a mesma solução salina de $15 \mathrm{~g} / \mathrm{L}$ de $\mathrm{NaCl}$, porém em pH 2,0. Em seguida, a contagem foi realizada em câmara de Neubauer.

\subsubsection{Determinação das Concentrações de Açúcares e Etanol}

As concentrações dos açúcares (glicose e frutose), bem como de etanol, dos experimentos realizados em escala de laboratório, foram determinadas por Cromatografia Líquida de Alta Eficiência (HPLC) conforme metodologia previamente desenvolvida no DEBIQ. Para tanto, as amostras foram previamente diluídas e filtradas em filtro "Sep Pack” C18 (MILLIPORE). Para a análise por HPLC, utilizou-se o ácido sulfúrico 0,005 M como fase móvel, fluxo de $0,6 \mathrm{~mL} / \mathrm{min}$, detector de indíce de refração (RI), temperatura de $45{ }^{\circ} \mathrm{C}$ e coluna BIO-RAD HPX-87H.

A determinação do teor de sólidos solúveis ( ${ }^{\circ}$ Brix) do mosto, foi realizada por meio de leitura direta em refratômetro portátil, modelo RHW-25bATC. O teor de sólidos solúveis do vinho foi determinado por meio de peso seco utilizando uma termobalança BEL engineering modelo Top-ray.

Para a determinação do teor alcoólico, as amostras de vinho foram submetidas a um processo de destilação em escala de laboratório. Posteriormente, o teor alcoólico do destilado foi determinado por meio de leitura direta utilizando um densímetro digital portátil Anton Paar DMA35. 


\subsection{Parâmetros Fermentativos}

\subsubsection{Rendimento}

O fator de rendimento da fermentação alcoólica foi calculado a partir da Equação 1:

$Y_{P / S}=\frac{\Delta P}{-\Delta S}=\frac{d p / d t}{d S / d t}=\frac{\left(P_{f}-P_{i}\right)}{\left(S_{i}-S_{f}\right)}=g / g$

Onde:

$\mathrm{P}_{\mathrm{f}}$ : concentração final de etanol $[\mathrm{g} / \mathrm{L}]$

$\mathrm{P}_{\mathrm{i}}$ : concentração inicial de etanol $[\mathrm{g} / \mathrm{L}]$

$\mathrm{S}_{\mathrm{f}}$ : concentração final de açúcares $[\mathrm{g} / \mathrm{L}]$

$\mathrm{S}_{\mathrm{i}}$ : concentração inicial de açúcares $[\mathrm{g} / \mathrm{L}]$

\subsubsection{Eficiência de Fermentação ( $\eta \%)$}

A eficiência de fermentação foi calculada com base no rendimento teórico proveniente da equação de Gay-Lussac e de acordo com a Equação 2, onde:

$Y_{P / S}$ teórico $=0,511 \mathrm{~g}$ etanol $/ \mathrm{g}$ glicose

$$
\eta(\%)=\left(\frac{Y_{\mathrm{P} / \mathrm{s}} \text { obtido }}{Y_{\mathrm{P} / \mathrm{S}} \text { teórico }}\right) \times 100
$$

\subsubsection{Produtividade}

A produtividade em etanol foi calculada conforme equação 3: 
$Q_{P}=\frac{\left(P_{f}-P_{i}\right)}{t}=g / L \cdot h^{-1}$

Onde:

$\mathrm{P}_{\mathrm{f}}$ : concentração final de etanol $[\mathrm{g} / \mathrm{L}]$

$\mathrm{P}_{\mathrm{i}}$ : concentração inicial de etanol $[\mathrm{g} / \mathrm{L}]$

$\mathrm{t}$ : tempo total de fermentação [h] 


\section{RESULTADOS E DISCUSSÃO}

\subsection{Seleção das Leveduras}

As cepas de leveduras avaliadas no presente trabalho (Tabela 3) foram isoladas de frutas e de mel, incluindo abacaxi (Ananas comosus), mexerica (Citrus reticulata), uva (Vittis sp.) e acerola (Malpighia glabra) obtidas no comércio local. Para o isolamento das leveduras a partir de mel, foram utilizados mel não centrifugado e resíduo do processamento de mel obtidos após a etapa de sedimentação (borra do mel). Como referência, avaliou-se também a levedura comercial Saccharomyces cerevisiae Ca 116, que foi devidamente selecionada por Mendonça (1999) para produção de cachaça de alambique.

Tabela 3 - Codificação das leveduras e sua origem.

\begin{tabular}{c|c}
\hline Código & Origem \\
\hline $\mathrm{B}$ & Uva Utália \\
\hline $\mathrm{D}$ & Uva Itália \\
\hline $\mathrm{H}$ & Mexerica \\
\hline $\mathrm{K}$ & Abacaxi \\
\hline $\mathrm{M}$ & Acerola \\
\hline $\mathrm{N}$ & Acerola \\
\hline $\mathrm{P}$ & Mel não centrifugado \\
\hline $\mathrm{Q}$ & Mel não centrifugado \\
\hline $\mathrm{T}$ & Borra de mel \\
\hline $\mathrm{V}$ & S. cerevisiae Ca 116
\end{tabular}

As referidas leveduras foram avaliadas em escala de laboratório em tubos de ensaio, quanto ao desempenho fermentativo em mosto constituído de mel $15{ }^{\circ}$ Brix suplementado, individualmente, com diferentes nutrientes, incluindo extrato de levedura comercial (10,0 g/L), extrato de farelo de arroz $(20,0 \mathrm{~g} / \mathrm{L})$, nutriente comercial - D\&R $(0,15 \mathrm{~g} / \mathrm{L})$ e mistura $(1,0 \mathrm{~g} / \mathrm{L})$ constituída de farelos de milho, arroz e soja na proporção 5:2:5. Como parâmetro de avaliação considerou-se a produção de etanol, consumo de açúcar e crescimento celular, cujos resultados encontram-se apresentados nas Tabelas 4, 5 e 6 , respectivamente. 
Tabela 4 - Concentração de etanol (g/L) produzido pelas leveduras selecionadas, em mosto constituído de Mel $15{ }^{\circ}$ Brix suplementado, com diferentes nutrientes. Extrato de Levedura

\begin{tabular}{|c|c|c|c|c|c|c|c|c|c|c|c|c|}
\hline \multirow{2}{*}{ Leveduras } & \multicolumn{4}{|c|}{$\begin{array}{c}\text { Extrato de Levedura } \\
\text { Tempo de fermentação [h] }\end{array}$} & \multicolumn{4}{|c|}{$\begin{array}{c}\text { Farelo de Arroz } \\
\text { Tempo fermentação [h] }\end{array}$} & \multicolumn{4}{|c|}{$\begin{array}{c}\text { Nutriente Comercial D\&R } \\
\text { Tempo fermentação [h] }\end{array}$} \\
\hline & 12 & 18 & 24 & 36 & 12 & 18 & 24 & 36 & 12 & 18 & 24 & 36 \\
\hline B & 3,75 & 5,74 & 5,77 & 5,89 & 6,80 & 8,95 & 12,25 & 17,75 & 1,75 & 2,25 & 7,50 & 4,00 \\
\hline $\mathrm{D}$ & 0,80 & 3,82 & 4,79 & 9,17 & 7,25 & 11,75 & 12,25 & 20,25 & 1,00 & 6,50 & 8,50 & 13,25 \\
\hline $\mathrm{H}$ & 1,08 & 2,17 & 4,09 & 5,55 & 4,49 & 5,68 & 10,19 & 14,68 & 1,25 & 3,00 & 8,50 & 11,00 \\
\hline $\mathrm{K}$ & 3,73 & 4,98 & 6,85 & 7,54 & 3,63 & 4,99 & 13,15 & 16,52 & 1,43 & 3,75 & 7,03 & 12,12 \\
\hline $\mathrm{M}$ & 0,21 & 1,04 & 1,30 & 3,21 & 3,85 & 6,25 & 13,02 & 16,70 & 1,95 & 5,75 & 6,17 & 8,00 \\
\hline $\mathrm{N}$ & 0,28 & 1,58 & 1,80 & 1,95 & 2,37 & 2,88 & 8,02 & 11,38 & 0,16 & 9,50 & 10,58 & 15,75 \\
\hline $\mathrm{P}$ & 3,91 & 6,47 & 13,41 & 23,77 & 12,30 & 11,89 & 4,87 & 2,82 & 2,75 & 3,75 & 5,00 & 5,75 \\
\hline$Q$ & 1,93 & 2,24 & 2,41 & 3,63 & 5,52 & 6,79 & 9,20 & 12,78 & 0,13 & 0,25 & 0,75 & 3,93 \\
\hline $\mathrm{T}$ & 19,04 & 28,49 & 28,57 & 30,70 & 5,73 & 12,4 & 14,58 & 25,22 & 6,22 & 12,00 & 17,50 & 26,00 \\
\hline $\mathrm{V}$ & 18,94 & 24,69 & 26,22 & 31,28 & 4,98 & 10,33 & 12,62 & 15,04 & 1,03 & 8,75 & 10,62 & 20,25 \\
\hline
\end{tabular}

Tabela 4 - (continuação).

\begin{tabular}{c|c|c|c|c|c|c|c|c}
\hline & \multicolumn{3}{c|}{$\begin{array}{c}\text { Milho: Arroz: Soja } \\
\text { Tempo fermentação [h] }\end{array}$} & \multicolumn{4}{c}{ Tempo fermentação [h] } \\
\hline Leveduras & $\mathbf{1 2}$ & $\mathbf{1 8}$ & $\mathbf{2 4}$ & $\mathbf{3 6}$ & $\mathbf{1 2}$ & $\mathbf{1 8}$ & $\mathbf{2 4}$ & $\mathbf{3 6}$ \\
\hline $\mathrm{B}$ & 3,50 & 7,50 & 13,25 & 18,00 & 0,60 & 1,02 & 1,64 & 3,42 \\
\hline $\mathrm{D}$ & 8,75 & 14,75 & 21,25 & 24,00 & 0,11 & 0,60 & 1,18 & 3,95 \\
\hline $\mathrm{H}$ & 8,25 & 11,50 & 20,50 & 23,00 & 0,29 & 1,09 & 2,19 & 3,21 \\
\hline $\mathrm{K}$ & 3,75 & 9,00 & 16,25 & 19,00 & 0,51 & 0,99 & 1,50 & 3,99 \\
\hline $\mathrm{M}$ & 9,75 & 14,25 & 19,25 & 19,00 & 0,56 & 2,52 & 2,41 & 3,42 \\
\hline $\mathrm{N}$ & 5,75 & 6,75 & 8,25 & 12,00 & 0,46 & 0,48 & 0,50 & 0,54 \\
\hline $\mathrm{P}$ & 7,50 & 8,00 & 8,25 & 8,75 & 0,33 & 0,63 & 0,87 & 9,87 \\
\hline $\mathrm{Q}$ & 3,00 & 7,50 & 10,50 & 13,75 & 0,21 & 0,62 & 1,63 & 3,11 \\
\hline $\mathrm{T}$ & 10,50 & 13,00 & 13,75 & 22,00 & 4,53 & 5,24 & 7,15 & 10,94 \\
\hline $\mathrm{V}$ & 6,99 & 14,97 & 17,22 & 24,22 & 4,94 & 5,59 & 5,92 & 9,68 \\
\hline
\end{tabular}


Tabela 5 - Açúcar consumido (\%) pelas leveduras selecionadas, em mosto constituído de Mel $15{ }^{\circ}$ Brix suplementado, com diferentes nutrientes.

\begin{tabular}{|c|c|c|c|c|c|c|c|c|c|c|c|c|}
\hline \multirow[b]{2}{*}{ Leveduras } & \multicolumn{4}{|c|}{$\begin{array}{c}\text { Extrato de Levedrua } \\
\text { Tempo de fermentação [h] }\end{array}$} & \multicolumn{4}{|c|}{$\begin{array}{c}\text { Farelo de Arroz } \\
\text { Tempo fermentação [h] }\end{array}$} & \multicolumn{4}{|c|}{$\begin{array}{c}\text { Nutriente Comercial D\&R } \\
\text { Tempo fermentação [h] }\end{array}$} \\
\hline & 12 & 18 & 24 & 36 & 12 & 18 & 24 & 36 & 12 & 18 & 24 & 36 \\
\hline $\mathrm{B}$ & 10,26 & 11,76 & 13,66 & 24,59 & 31,42 & 35,89 & 50,23 & 70,54 & 37,02 & 41,60 & 67,56 & 70,99 \\
\hline $\mathrm{D}$ & 6,37 & 14,95 & 18,07 & 34,40 & 27,15 & 38,32 & 54,89 & 86,83 & 26,43 & 52,23 & 59,24 & 65,92 \\
\hline $\mathrm{H}$ & 2,22 & 5,49 & 12,65 & 18,98 & 32,52 & 42,27 & 54,93 & 68,53 & 12,20 & 25,92 & 45,24 & 74,70 \\
\hline $\mathrm{K}$ & 6,82 & 10,14 & 19,45 & 24,07 & 30,81 & 49,39 & 74,04 & 80,86 & 33,45 & 51,96 & 61,92 & 82,21 \\
\hline $\mathrm{M}$ & 14,99 & 15,97 & 16,02 & 29,57 & 22,83 & 35,55 & 72,72 & 78,16 & 24,89 & 58,23 & 70,89 & 91,51 \\
\hline $\mathrm{N}$ & 0,78 & 3,90 & 5,35 & 5,73 & 21,12 & 23,74 & 47,10 & 56,59 & 1,09 & 43,72 & 44,54 & 58,47 \\
\hline $\mathrm{P}$ & 8,04 & 13,57 & 27,68 & 52,42 & 72,4 & 73,70 & 84,91 & 85,81 & 70,51 & 77,79 & 78,21 & 78,21 \\
\hline$Q$ & 17,05 & 17,51 & 17,79 & 26,28 & 30,98 & 33,02 & 49,47 & 87,83 & 22,22 & 35,98 & 58,73 & 73,54 \\
\hline $\mathrm{T}$ & 39,15 & 55,11 & 73,08 & 81,70 & 12,99 & 22,34 & 22,65 & 39,91 & 23,96 & 45,05 & 54,51 & 76,48 \\
\hline $\mathrm{V}$ & 42,62 & 63,95 & 71,92 & 85,59 & 16,23 & 28,17 & 35,35 & 47,94 & 3,29 & 31,51 & 39,04 & 70,68 \\
\hline
\end{tabular}

Tabela 5 - (continuação).

\begin{tabular}{c|c|c|c|c|c|c|c|c}
\hline & \multicolumn{3}{c}{$\begin{array}{c}\text { Milho: Arroz: Soja } \\
\text { Tempo fermentação [h] }\end{array}$} & \multicolumn{4}{c}{$\begin{array}{c}\text { Controle } \\
\text { Tempormentação [h] }\end{array}$} \\
\hline Leveduras & $\mathbf{1 2}$ & $\mathbf{1 8}$ & $\mathbf{2 4}$ & $\mathbf{3 6}$ & $\mathbf{1 2}$ & $\mathbf{1 8}$ & $\mathbf{2 4}$ & $\mathbf{3 6}$ \\
\hline $\mathrm{B}$ & 21,37 & 44,05 & 60,13 & 77,09 & 1,84 & 3,10 & 4,20 & 15,92 \\
\hline $\mathrm{D}$ & 18,87 & 36,52 & 52,94 & 58,82 & 9,88 & 16,36 & 21,04 & 18,41 \\
\hline $\mathrm{H}$ & 24,07 & 33,88 & 57,48 & 55,14 & 4,94 & 5,79 & 10,53 & 14,74 \\
\hline $\mathrm{K}$ & 23,33 & 55,78 & 61,11 & 81,11 & 1,58 & 2,36 & 3,08 & 7,17 \\
\hline $\mathrm{M}$ & 23,58 & 34,43 & 47,88 & 51,18 & 2,72 & 8,04 & 8,20 & 8,65 \\
\hline $\mathrm{P}$ & 35,55 & 40,03 & 40,03 & 40,03 & 1,52 & 1,60 & 2,01 & 2,25 \\
\hline $\mathrm{Q}$ & 43,33 & 89,33 & 90,67 & 91,33 & 0,78 & 9,65 & 18,55 & 36,65 \\
\hline $\mathrm{T}$ & 19,29 & 44,76 & 68,33 & 69,05 & 2,80 & 7,38 & 11,60 & 13,65 \\
\hline $\mathrm{V}$ & 33,26 & 35,52 & 52,49 & 70,81 & 7,44 & 11,93 & 25,01 & 30,73 \\
\hline
\end{tabular}


Tabela 6 - Concentração celular $\left(x 1^{7}\right)$ das leveduras selecionadas, em mosto constituído de Mel $15^{\circ}$ Brix suplementado, com diferentes nutrientes. Extrato de Levedrua Farelo de Arroz Tempo de fermentação [h]

\begin{tabular}{c|c|c|c|c|c|c|c|c|c|c|c|c} 
& \multicolumn{4}{c}{ Tempo de fermentação [h] } & \multicolumn{4}{c}{ Tempo fermentação [h] } & \multicolumn{3}{c}{ Tempo fermentação [h] } \\
\hline Leveduras & $\mathbf{1 2}$ & $\mathbf{1 8}$ & $\mathbf{2 4}$ & $\mathbf{3 6}$ & $\mathbf{1 2}$ & $\mathbf{1 8}$ & $\mathbf{2 4}$ & $\mathbf{3 6}$ & $\mathbf{1 2}$ & $\mathbf{1 8}$ & $\mathbf{2 4}$ & $\mathbf{3 6}$ \\
\hline $\mathrm{B}$ & 0,08 & 0,08 & 0,18 & 0,49 & 0,63 & 1,19 & 2,81 & 4,81 & 1,63 & 3,69 & 3,69 & 4,13 \\
\hline $\mathrm{D}$ & 0,09 & 0,13 & 0,23 & 0,40 & 2,00 & 2,13 & 3,13 & 3,13 & 2,13 & 3,25 & 6,63 & 6,56 \\
\hline $\mathrm{H}$ & 0,10 & 0,85 & 0,91 & 0,76 & 0,13 & 0,25 & 1,13 & 1,63 & 2,06 & 4,06 & 4,25 & 3,81 \\
\hline $\mathrm{K}$ & 0,48 & 0,81 & 1,34 & 0,51 & 1,33 & 2,45 & 4,08 & 4,89 & 0,88 & 6,44 & 4,56 & 4,31 \\
\hline $\mathrm{M}$ & 0,18 & 0,85 & 1,20 & 1,31 & 1,38 & 1,75 & 3,13 & 2,06 & 1,00 & 3,88 & 4,81 & 6,88 \\
\hline $\mathrm{N}$ & 0,15 & 0,18 & 0,24 & 1,00 & 0,31 & 2,44 & 2,06 & 1,06 & 1,81 & 3,19 & 2,38 & 1,94 \\
\hline P & 2,05 & 2,71 & 3,53 & 0,46 & 2,13 & 2,50 & 5,19 & 6,19 & 5,75 & 8,19 & 10,44 & 8,31 \\
\hline Q & 0,13 & 1,55 & 2,10 & 4,31 & 2,19 & 2,69 & 2,81 & 5,44 & 2,31 & 5,00 & 5,13 & 5,06 \\
\hline T & 4,50 & 7,88 & 9,00 & 14,56 & 2,99 & 3,36 & 3,39 & 4,89 & 1,81 & 2,56 & 6,56 & 6,65 \\
\hline V & 3,88 & 6,31 & 8,06 & 8,38 & 2,78 & 2,81 & 3,56 & 4,31 & 2,81 & 4,81 & 6,06 & 6,88 \\
\hline
\end{tabular}

Tabela 6 - (continuação).

\begin{tabular}{c|c|c|c|c|c|c|c|c}
\hline & \multicolumn{3}{|c|}{$\begin{array}{c}\text { Milho: Arroz: Soja } \\
\text { Tempo fermentação [h] }\end{array}$} & \multicolumn{4}{c}{$\begin{array}{c}\text { Controle } \\
\text { Tempo fermentação [h] }\end{array}$} \\
\hline Leveduras & $\mathbf{1 2}$ & $\mathbf{1 8}$ & $\mathbf{2 4}$ & $\mathbf{3 6}$ & $\mathbf{1 2}$ & $\mathbf{1 8}$ & $\mathbf{2 4}$ & $\mathbf{3 6}$ \\
\hline $\mathrm{B}$ & 0,63 & 2,94 & 6,25 & 4,69 & 0,25 & 1,14 & 1,68 & 2,21 \\
\hline $\mathrm{D}$ & 1,38 & 2,13 & 4,50 & 3,25 & 0,65 & 0,73 & 1,46 & 2,01 \\
\hline H & 2,25 & 3,69 & 4,13 & 4,69 & 0,75 & 2,10 & 2,10 & 2,08 \\
\hline K & 1,06 & 3,44 & 4,44 & 4,63 & 0,05 & 0,43 & 0,79 & 1,13 \\
\hline M & 0,09 & 0,34 & 0,59 & 0,90 & 0,09 & 0,35 & 0,90 & 0,95 \\
\hline N & 0,56 & 0,75 & 1,19 & 2,69 & 0,09 & 2,01 & 2,41 & 2,40 \\
\hline P & 5,75 & 5,88 & 5,95 & 6,25 & 1,06 & 1,56 & 1,75 & 1,50 \\
\hline Q & 2,25 & 2,50 & 4,38 & 5,38 & 0,79 & 2,01 & 3,23 & 3,16 \\
\hline T & 4,88 & 6,06 & 7,44 & 11,25 & 2,80 & 3,18 & 3,61 & 5,36 \\
\hline V & 3,56 & 7,81 & 6,81 & 4,88 & 2,83 & 3,08 & 3,20 & 3,33 \\
\hline
\end{tabular}


Os resultados apresentados na Tabela 4 mostram que, após 36 horas de fermentação as leveduras $\mathrm{T}$ e $\mathrm{V}$ se destacaram entre as demais nos diferentes meios avaliados, sendo que no meio suplementado com extrato de levedura produziram uma quantidade de etanol equivalente a 30,70 g/L e 31,28 g/L respectivamente. Verifica-se que estes valores foram $180 \%$ e $223 \%$, superiores aos obtidos no meio controle, que corresponderam a 10,94 g/L e 9,68 g/L., respectivamente.

Verifica-se ainda que a levedura T também apresentou um desempenho satisfatório nos meios suplementados com farelo de arroz e nutriente comercial D\&R produzindo $25,22 \mathrm{~g} / \mathrm{L}$ e 26,00 g/L, de etanol, respectivamente. Nota-se que estes valores são $130 \% \mathrm{e}$ $137 \%$ maiores que os obtidos no meio controle $(10,94 \mathrm{~g} / \mathrm{L})$. Por outro lado, quando o mosto foi suplementado com a mistura constituída de milho: arroz: soja, os isolados $\mathrm{V}$ $(24,22 \mathrm{~g} / \mathrm{L}), \mathrm{D}(24,00 \mathrm{~g} / \mathrm{L}), \mathrm{H}(23,00 \mathrm{~g} / \mathrm{L})$ e $\mathrm{T}(22,00 \mathrm{~g} / \mathrm{L})$ apresentaram melhor desempenho quando comparado com o meio controle cujos valores de produção de etanol corresponderam a 9,68; 3,95; 3,21 e 10,94 g/L, respectivamente.

Desta forma, com referência a produção de etanol nos diferentes meios avaliados, constata-se a necessidade de suplementação com nutrientes, do mosto formulado com mel, para atender as exigências nutricionais dos isolados de levedura em estudo.

No tocante ao consumo de açúcar (Tabela 5), verifica-se que as leveduras avaliadas apresentaram melhor desempenho quando o meio foi suplementado com algum tipo de nutriente. Assim, das 10 leveduras estudadas, 7 apresentaram um consumo de açúcar superior a $80 \%$ após 36 horas de fermentação quando o mosto foi suplementado com nutrientes.

Observa-se ainda que o uso de extrato de levedura como suplemento no meio favoreceu o consumo de açúcar, principalmente pelas leveduras T $(81,70 \%)$ e V $(85,59 \%)$. Estes valores foram $165 \%$ e $123 \%$ superiores aos obtidos no meio controle, onde o consumo de açúcar foi apenas de 30,73\% e 38,24\% respectivamente. Quando o meio foi suplementado com farelo de arroz, nutriente comercial D\&R e mistura de Milho:Arroz:Soja, os valores de consumo de açúcar pelas leveduras T e V foram 39,91\% e $47,94 \%, 76,48 \%$ e $70,68 \%, 70,81$ e $75,38 \%$ respectivamente, valores estes superiores aos obtidos no meio controle.

No que se refere a formação de massa celular, os resultados apresentados na Tabela 6 demonstram que a concentração celular para a maioria das leveduras estudadas, atingiu 
valores na ordem de $10^{7}$ células/mL após 36 horas de fermentação nos diferentes meios estudados. Nota-se ainda que no mosto suplementado com extrato de levedura, a concentração celular referente a levedura $\mathrm{T}$ aumentou consideravelmente, atingindo 1,456 x $10^{8}$ células/mL após 36 horas de fermentação, o que equivale a $171 \%$ superior à concentração celular encontrada no meio controle $\left(5,36 \times 10^{7}\right.$ céluas $\left./ \mathrm{mL}\right)$. Verifica-se ainda que quando o mosto foi suplementado com a mistura Milho:Arroz:Soja, o crescimento da levedura $\mathrm{T}$ também pode ser destacado, sendo que neste meio, a máxima concentração celular atingida após 36 horas de fermentação foi de $1,125 \times 10^{8}$ células/mL. Nota-se ainda que para o mesmo período, no meio controle, a concentração celular referente a levedura $\mathrm{T}$ foi de $5,36 \times 10^{7}$ células $/ \mathrm{mL}, 52 \%$ inferior à concentração celular no meio suplementado com a referida mistura.

Vale ressaltar que, quando se avaliou o farelo de arroz como suplemento nutricional as leveduras estudadas mantiveram uma concentração celular na ordem de $10^{7}$ células $/ \mathrm{mL}$ e, quando o meio foi suplementado com nutriente comercial D\&R, a levedura P atingiu uma concentração de $1,044 \times 10^{8}$ células $/ \mathrm{mL}$ após 24 horas, ao passo que no meio controle esta concentração ficou na ordem de $1,75 \times 10^{7}$ células $/ \mathrm{mL}$.

Com base nos resultados apresentados nas Tabelas 4, 5 e 6, é possível verificar que das 10 leveduras avaliadas, $5(\mathrm{D}, \mathrm{H}, \mathrm{P}, \mathrm{T}$ e $\mathrm{V})$ apresentam características promissoras para serem avaliadas como agentes de fermentação alcoólica, o que sugere a realização de novos estudos.

Especificamente, a análise dos resultados apresentados nas Tabelas 4 e 5 revelam que as leveduras T e V demonstraram melhor desempenho, após 36 horas de fermentação, em mosto formulado com mel suplementado com os diferentes nutrientes avaliados. Desta forma, estes resultados foram empregados para se calcular os respectivos parâmetros de fermentação compreendendo rendimento $(\mathrm{Yp} / \mathrm{s})$, eficiência $(\eta)$ e produtividade em etanol (Qp), cujos resultados se encontram apresentados na Tabela 7. 
Tabela 7 - Parâmetros fermentativos referentes as leveduras selecionadas, em mosto constituído de Mel $15^{\circ}$ Brix suplementado, com diferentes nutrientes.

\begin{tabular}{|c|c|c|c|c|c|c|}
\hline \multirow[b]{2}{*}{ Meio } & \multicolumn{3}{|c|}{ Levedura T } & \multicolumn{3}{|c|}{ Levedura V } \\
\hline & $\begin{array}{l}Y_{P / S} \\
{[g / g]}\end{array}$ & $\begin{array}{c}\eta \\
{[\%]}\end{array}$ & $\begin{array}{c}\mathbf{Q}_{\mathbf{P}} \\
{\left[\mathrm{g} / \mathrm{L} \cdot \mathrm{h}^{-1}\right]}\end{array}$ & $\begin{array}{l}Y_{\mathbf{P} / \mathbf{S}} \\
{[\mathbf{g} / \mathbf{g}]}\end{array}$ & $\begin{array}{c}\eta \\
{[\%]}\end{array}$ & $\begin{array}{c}\mathbf{Q}_{\mathbf{P}} \\
{\left[\mathrm{g} / \mathbf{L} \cdot \mathrm{h}^{-1}\right]}\end{array}$ \\
\hline Ext. Lev. & 0,36 & 70,69 & 0,85 & 0,34 & 66,76 & 0,87 \\
\hline Fa. Arroz & 0,47 & 91,96 & 0,70 & 0,19 & 37,45 & 0,42 \\
\hline $\mathrm{M}: \mathrm{A}: \mathrm{S}$ & 0,30 & 58,48 & 0,72 & 0,31 & 61,44 & 0,56 \\
\hline Nut.D\&R & 0,28 & 55,02 & 0,61 & 0,30 & 58,41 & 0,67 \\
\hline Controle & 0,20 & 39,08 & 0,30 & 0,15 & 28,43 & 0,27 \\
\hline
\end{tabular}

A análise destes resultados demonstra a necessidade de suplementação do mosto, tendo em vista que as leveduras selecionadas apresentaram melhor desempenho no mosto suplementado com os respectivos nutrientes. Desta forma, considerando-se o parâmetro produtividade, verifica-se que as leveduras $\mathrm{T}$ e $\mathrm{V}$ se desenvolveram melhor no meio suplementado com extrato de levedura.

No tocante aos parâmetros rendimento e eficiência de fermentação nota-se que as leveduras $\mathrm{T}$ e $\mathrm{V}$ apresentaram melhor desempenho quando o mosto foi suplementado com farelo de arroz e extrato de levedura, correspondendo aos valores de 0,47 g/g (91,96\%) e $0,34 \mathrm{~g} / \mathrm{g}(66,52 \%)$, respectivamente. Verifica-se ainda (Tabelas 4) que a produção de etanol pela levedura $\mathrm{T}$ foi maior no mosto suplementado com extrato de levedura $(30,70$ g/L) quando comparado com a suplementação do meio com farelo de arroz $(25,55 \mathrm{~g} / \mathrm{L})$. Nota-se também (Tabela 5) que a porcentagem de açúcar consumido por esta cepa $(81,70 \%)$ foi superior no meio suplementado com extrato de levedura em relação a suplementação com farelo de arroz (39,91\%). Desta forma, verificou-se que o farelo de arroz favoreceu a conversão do açúcar em etanol conferindo um maior rendimento e eficiência da fermentação, porém, desfavoreceu a capacidade da levedura em consumir o açúcar presente no meio.

Assim, considerando-se o parâmetro produtividade, o baixo consumo de açúcar no mosto suplementado com farelo de arroz e o fato que Saccharomyces cereviseae CA 116 (levedura V) é uma cepa que tem sido empregada no processo de produção de cachaça de alambique, portanto, já conhecida pelos produtores, selecionou-se a levedura $\mathrm{T}$ (isolada de borra de mel) e a suplementação do mosto com extrato de levedura comercial para dar continuidade aos trabalhos em escala piloto. 
Observou-se também que a levedura $\mathrm{T}$ apresenta a propriedade de flocular, nas condições estudadas, o que contribui para o desenvolvimento do processo de fermentação por meio do sistema de batelada repetida. Esta característica de flocular é considerada positiva, uma vez que facilita a separação do fermento e remoção do vinho no final do processo fermentativo (DOMINGUES, 2001), reduzindo, assim, o tempo de processo. Neste contexto, é válido mencionar que dentre as inovações que tem sido introduzidas no processo de produção de cachaça de alambique destacam-se os procedimentos de isolamento e caracterização de cepas de leveduras com ênfase para aquelas que apresentam melhor desempenho fermentativo associado à propriedade floculante (PACHECO, 2010) tendo como exemplo Saccharomyces cereviseae CA 116.

Os isolados de levedura avaliados no presente trabalho foram devidamente identificados segundo metodologia proposta por Magalhães et al. (2010), cujos resultados encontram-se apresentados na Tabela 8.

Tabela 8- Identificação das leveduras.

\begin{tabular}{c|c|c}
\hline Código & Origem & Espécie \\
\hline B & Uva Utália & Pichia kluyveri \\
\hline D & Uva Itália & Pichia fermentans \\
\hline H & Mexerica & Pichia kluyveri \\
\hline K & Abacaxi & Pichia kluyveri \\
\hline M & Acerola & Pichia fermentans \\
\hline N & Acerola & Pichia kluyveri \\
\hline P & Mel não centrifugado & NI* \\
\hline Q & Mel não centrifugado & Pichia kluyveri \\
\hline T & Borra de mel & S. cerevisiae \\
\hline V & S. cerevisiae Ca 116 & S. cerevisiae Ca 116 \\
\hline
\end{tabular}

*Não identificada

Observa-se que os isolados de frutas, e um isolado de mel não centrifugado, foram identificadas como sendo espécies do gênero Pichia, sendo Pichia fermentans isolada de uva itália e Pichia kluyveri isolada de acerola. Arias et al. (2002) relatam que algumas espécies do gênero Pichia são comumente encontradas em sucos cítricos, dentre elas a espécie Pichia kluyveri. McNamee et al. (2010) citam a levedura Pichia fermentans como uma levedura deteriorante frequentemente isolada do suco de laranja.

A levedura isolada de borra de mel, avaliada neste trabalho para a produção de aguardente em escala piloto, é uma cepa de Saccharomyces cerevisiae, espécie encontrada em maior abundância em fermentações para produção de aguardente (MORAIS et al., 
1997; SCHWAN et al., 2001) destacando-se pela alta produção e tolerância a concentrações elevadas de etanol (SILVA et al., 2009).

Badotti et al. (2010) relatam que Saccharomyces cerevisiae é a espécie de levedura predominante no mosto utilizado na produção de cachaça artesanal, por sua maior tolerância ao estresse osmótico e ao etanol, mas os gêneros Kloeckera, Candida, Kluyveromyces e Pichia também são comumente isolados.

A espécie Saccharomyces cerevisiae isolada da borra de mel e utilizada neste trabalho foi nomeada Saccharomyces cerevisiae EEL 2009 e será posteriormente depositada em banco de leveduras.

\subsection{Produção de Aguardente de Mel em Escala Piloto}

$\mathrm{Na}$ etapa anterior do presente trabalho demonstrou-se que a levedura $\mathrm{T}$ apresentou melhor desempenho fermentativo em mosto constituído de mel $15^{\circ}$ Brix, suplementado com extrato de levedura comercial. Desta forma, estas condições foram adotadas no sentido de se avaliar o processo de produção de aguardente de mel em escala piloto junto às instalações do Alambique da Associação Rural de Canas, Canas-SP.

O processo de fermentação para a produção da aguardente de mel em escala piloto foi realizado por meio do sistema de batelada repetida em 5 ciclos consecutivos, sendo o vinho submetido ao processo de destilação fracionada em 2 alambiques de cobre com capacidade de $150 \mathrm{~L}$ cada. O volume total de mosto preparado, em cada batelada, foi de 300 L. A fração "coração" foi devidamente recolhida, caracterizada e armazenada em tonel de carvalho de $200 \mathrm{~L}$ de capacidade. Os resultados referentes a caracterização do mosto e do vinho ao longo das referidas bateladas encontram-se apresentados na Tabela 9. 
Tabela 9 - Caracterização do mosto e do vinho no processo de produção de aguardente de mel em escala piloto.

\begin{tabular}{c|c|c|c|c|c|c|c|c|c}
\hline \multirow{2}{*}{ Características } & \multicolumn{2}{c}{${ }^{\mathbf{0}}$ Brix } & \multicolumn{2}{c|}{$\begin{array}{c}\text { Etanol } \\
{\left[{ }^{\mathbf{0}} \mathbf{G L ]}\right.}\end{array}$} & $\begin{array}{c}\text { Acidez } \\
\text { Sulfúrica } \\
\text { [g/L] }\end{array}$ & \multicolumn{2}{c|}{$\mathbf{p H}$} & $\begin{array}{c}\text { Tempo de } \\
\text { fermentação } \\
\text { [h] }\end{array}$ \\
\hline Batelada & Inicial & Final & Inicial & Final & Mosto & Vinho & Mosto & Vinho & \\
\hline 1 & 15,50 & 1,13 & 0,00 & 6,70 & 0,65 & 1,25 & 4,86 & 3,67 & 40,25 \\
\hline 2 & 15,60 & 1,74 & 1,41 & 7,80 & 0,71 & 1,13 & 4,62 & 3,95 & 40,33 \\
\hline 3 & 15,60 & 2,61 & 1,64 & 7,50 & 0,71 & 1,07 & 4,60 & 3,64 & 24,50 \\
\hline 4 & 15,20 & 2,46 & 1,57 & 7,30 & 0,77 & 1,19 & 4,56 & 3,74 & 21,30 \\
\hline 5 & 15,80 & 2,85 & 1,53 & 7,30 & 0,83 & 1,25 & 4,06 & 3,71 & 21,00 \\
\hline Média & $\mathbf{1 5 , 5 4}$ & $\mathbf{2 , 1 5}$ & $\mathbf{1 , 2 3}$ & $\mathbf{7 , 3 2}$ & $\mathbf{0 , 7 3}$ & $\mathbf{1 , 1 8}$ & $\mathbf{4 , 5 7}$ & $\mathbf{3 , 7 4}$ & $\mathbf{2 8 , 8 7}$ \\
\hline
\end{tabular}

No tocante a quantidade de açúcar consumido ( ${ }^{\circ}$ Brix inicial - ${ }^{\circ}$ Brix final), observase que ao final das 5 bateladas a média dos valores obtidos revela que $86,13 \%$ destes foram metabolizados produzindo em média $6,1^{\circ} \mathrm{GL}$ de etanol, o que demonstra um desempenho satisfatório por parte da levedura T.

Os resultados referentes a acidez titulável do mosto e do vinho, expressa em acidez sulfúrica, revelam o grau de higiene observado durante o preparo do mosto e condução das fermentações, tendo em vista que o aumento excessivo da acidez do vinho se deve a presença de contaminantes. Neste contexto vale destacar que a acidez natural do mosto e do vinho equivale a valores que variam de 1,0 a $1,5 \mathrm{~g} / \mathrm{L}$ e 2,0 a 3,0 g/L, respectivamente (LIMA, 1999).

Em referência a variação do pH, observado após a fermentação do mosto, nota-se que os valores obtidos estão condizentes com aqueles reportados na literatura tendo como referência a produção de fermentados de frutas (DIAS, D. R.; PANTOJA, L.; SCHWAN, 2010) e aguardente de cana (LIMA, 1999).

No que se refere ao tempo de fermentação observa-se que as fermentações foram mais rápidas ao longo das bateladas repetidas, devido, provavelmente, a adaptação da levedura às condições do processo.

Estes resultados (Tabela 9), permitiram avaliar o desempenho fermentativo da levedura $\mathrm{T}$ ao longo das 5 bateladas, por meio da determinação do fator de rendimento $\left(\mathrm{Y}_{\mathrm{p} / \mathrm{s}}\right)$, eficiência $(\eta)$ e produtividade $\left(\mathrm{Q}_{\mathrm{p}}\right)$, cujos resultados encontram-se apresentados na Tabela 10. Para tanto, vale destacar que a densidade do mosto e do vinho foram determinadas revelando valores equivalentes a $1,05 \mathrm{~g} / \mathrm{mL}$ e $0,99 \mathrm{~g} / \mathrm{mL}$, respectivamente. 
Tabela 10 - Parâmetros fermentativos referentes ao desempenho da lelvedura $T$ em processo de produção de aguardente de mel em escala piloto.

\begin{tabular}{c|c|c|c}
\hline Batelada & $\begin{array}{c}\mathbf{Y}_{\mathbf{p} / \mathbf{s}} \\
{[\mathbf{g} / \mathbf{g}]}\end{array}$ & $\begin{array}{c}\boldsymbol{\eta} \\
{[\mathbf{\%}]}\end{array}$ & $\begin{array}{c}\mathbf{Q}_{\mathbf{p}} \\
{\left[\mathbf{g} / \mathbf{L} \cdot \mathbf{h}^{\mathbf{- 1}}\right]}\end{array}$ \\
\hline 1 & 0,37 & 72,41 & 1,31 \\
\hline 2 & 0,37 & 72,41 & 1,25 \\
\hline 3 & 0,36 & 70,45 & 1,89 \\
\hline 4 & 0,36 & 70,45 & 2,12 \\
\hline 5 & 0,36 & 70,45 & 2,17 \\
\hline Média & $\mathbf{0 , 3 6}$ & $\mathbf{7 1 , 3 7}$ & $\mathbf{1 , 7 5}$ \\
\hline
\end{tabular}

Estes resultados permitem observar que os valores do fator de rendimento, bem como da eficiência da fermentação mantiveram-se praticamente constantes ao longo dos 5 ciclos de fermentação, ao passo que a produtividade aumentou progressivamente ao longo do processo. Desta forma, nota-se que a variação da produtividade entre a $1^{\mathrm{a}}$ e $5^{\mathrm{a}}$ bateladas foi $66 \%$ superior, o que se deve a redução do tempo de fermentação (Tabela 9) devido a adaptação da levedura às condições do processo.

Em um processo de produção de aguardente não se visa apenas a produção de etanol como produto principal do metabolismo da levedura e sim a produção de outros metabólitos que contribuem positivamente para a qualidade do produto. Desta forma, os valores obtidos para os parâmetros fermentativos avaliados demonstram que a levedura $\mathrm{T}$ apresentou um desempenho fermentativo satisfatório. Neste contexto, vale destacar que este desempenho será corroborado por meio da caracterização físico química e sensorial da aguardente obtida.

Ilha et al. (2008) ao avaliarem os parâmetros fermentativos obtidos na produção de hidromel, encontraram valores de rendimento $(0,41 \mathrm{~g} / \mathrm{g})$ e eficiência $(81,27 \%)$ superiores aos encontrados no presente trabalho. Segundo Hashizume (1983), mesmo em condições experimentais bem controladas, o rendimento mais elevado não ultrapassa $0,48 \mathrm{~g} / \mathrm{g}$ e, no processo industrial, o rendimento é ainda menor.

Leveduras isoladas em processo de produção de cachaça de alambique no Estado de Pernambuco, foram avaliadas quanto ao desempenho fermentativo por Nova et al (2009), em escala de laboratório, empregando caldo de cana filtrado como meio de fermentação. Os resultados demonstraram que os valores de fator de rendimento obtidos, para os diferentes isolados variaram de 0,08 a $0,19 \mathrm{~g} / \mathrm{g}$ para a maioria das leveduras, sendo que o valor máximo obtido foi de $0,41 \mathrm{~g} / \mathrm{g}$ para um isolado identificado como Saccharomyces cerevisiae. 
Bortilini, Sant'anna e Torres (2001) estudando o comportamento das fermentações alcoólica e acética em mosto formulado com suco de kiwi, encontraram valores de rendimento e eficiência da fermentação alcoólica que variaram de 0,39 a 0,47 g/g e 75,62 a $92,41 \%$, respectivamente. No entanto, os valores de produtividade reportados por estes autores variaram de $0,74 \mathrm{a} 2,00 \mathrm{~g} / \mathrm{L} \cdot \mathrm{h}^{-1}$, portanto inferiores aos obtidos no presente trabalho $\left(1,31\right.$ a $\left.2,17 \mathrm{~g} / \mathrm{L} \cdot \mathrm{h}^{-1}\right)$. Valores inferiores, que variaram de 0,10 a $0,28 \mathrm{~g} / \mathrm{L} \cdot \mathrm{h}^{-1}$, também foram reportados por Tessaro et al. (2010) ao avaliarem o processo de produção de vinagre a partir de mosto formulado com suco de laranja empregando Saccharomyces cerevisiae obtido a partir de fermento biológico comercial, como agente de fermentação.

\subsection{Avaliação Físico-química da Aguardente de Mel}

Conforme reportado anteriormente, a produção da respectiva aguardente foi realizada em escala piloto pelo sistema de batelada repetida em 5 ciclos consecutivos, sendo o vinho destilado pelo processo de destilação fracionada em 2 alambiques de cobre, sendo a fração "coração" recolhida e armazenada em tonel de carvalho de modo a se obter o volume de destilado suficiente para atingir $200 \mathrm{~L}$. Amostras dos destilados obtidos foram recolhidas e submetidas à análise fisico-química (Tabela 11).

Observa-se que a aguardente obtida na primeira batelada, nos alambiques 1 e 2, apresentou um teor de cobre $(5,21 \mathrm{mg} / \mathrm{L})$ ligeiramente superior ao nível estabelecido pela legislação (5,0 mg/L) (Tabela 11). Este resultado se deve, provavelmente, à deficiências na higienização dos referidos alambiques antes de se iniciar o processo de produção. Por outro lado, nota-se que nas bateladas seguintes, a aguardente obtida nos 2 alambiques apresentou teores de cobre dentro dos limites estabelecidos pela legislação brasileira, variando de 1,23 a 3,64 mg/L. Neste contexto, observa-se que estes valores são superiores aos obtidos para a aguardente de jabuticaba, onde o teor de cobre encontrado foi de 0,7 mg/L (ASQUIERI; SILVA; CÂNDIDO, 2009) e, para aguardente de polpa de banana prata $(1,7 \mathrm{mg} / \mathrm{L})$ e de casca de banana $(1,3 \mathrm{mg} / \mathrm{L})$ reportados por Silva et al. (2004) e para aguardente de cana submetida a um tratamento de irradiação com raios gama, no qual a cachaça foi introduzida no tonel de madeira e o conjunto (cachaça e tonel) foram irradiados, que foi de 1,31 mg/L (MIRANDA; HORII; ALCARDE, 2006). 
Tabela 11 - Caracterização físico química da aguardente de mel obtida em bateladas repetidas em dois alambiques de cobre.

\begin{tabular}{|c|c|c|c|c|c|c|c|c|c|c|}
\hline \multirow[t]{2}{*}{ Características } & \multicolumn{2}{|c|}{$\begin{array}{l}\text { Batelada } 1 \\
\text { Alambique }\end{array}$} & \multicolumn{2}{|c|}{$\begin{array}{l}\text { Batelada } 2 \\
\text { Alambique }\end{array}$} & \multicolumn{2}{|c|}{$\begin{array}{l}\text { Batelada } 3 \\
\text { Alambique }\end{array}$} & \multicolumn{2}{|c|}{$\begin{array}{l}\text { Batelada } 4 \\
\text { Alambique }\end{array}$} & \multicolumn{2}{|c|}{$\begin{array}{l}\text { Batelada } 5 \\
\text { Alambique }\end{array}$} \\
\hline & 1 & 2 & 1 & 2 & 1 & 2 & 1 & 2 & 1 & 2 \\
\hline $\begin{array}{l}\text { Densidade Relativa } \\
\left(20 / 20^{\circ} \mathrm{C}\right)\end{array}$ & 0,94427 & 0,94430 & 0,94257 & 0,94270 & 0,94260 & 0,94450 & 0,94162 & 0,94245 & 0,94207 & 0,94205 \\
\hline $\begin{array}{l}\text { Cobre } \\
(\mathrm{mg} / \mathrm{L})\end{array}$ & 5,21 & 5,21 & 2,74 & 3,64 & 1,23 & 2,64 & 2,19 & 2,66 & 2,05 & 2,54 \\
\hline $\begin{array}{c}\text { Extrato Seco a } 100^{\circ} \mathrm{C} \\
(\mathrm{g} / \mathrm{L})\end{array}$ & 0,136 & 0,144 & 0,096 & 0,116 & 0,136 & 0,116 & 0,128 & 0,100 & 0,056 & 0,036 \\
\hline $\begin{array}{c}\text { Grau Alcoólico Real a } 20^{\circ} \mathrm{C} \\
(\% \mathrm{~V} / \mathrm{V})\end{array}$ & 43,22 & 43,22 & 44,21 & 44,14 & 44,20 & 43,10 & 44,73 & 44,26 & 44,48 & 44,49 \\
\hline $\begin{array}{l}\text { Acidez Volátil em Ácido Acético } \\
\left(\mathrm{mg} / 100 \mathrm{~mL} \text { de } \mathrm{AA}^{*}\right)\end{array}$ & 34,69 & 34,69 & 23,74 & 27,17 & 23,74 & 24,35 & 23,46 & 27,10 & 26,96 & 26,96 \\
\hline $\begin{array}{c}\text { Álcool Superior } \\
\left(\mathrm{mg} / 100 \mathrm{~mL} \text { de } \mathrm{AA}^{*}\right)\end{array}$ & 169,61 & 173,09 & 143,84 & 165,76 & 185,03 & 186,58 & 184,37 & 196,21 & 164,19 & 196,73 \\
\hline $\begin{array}{c}\text { Furfural } \\
\left(\mathrm{mg} / 100 \mathrm{~mL} \text { de } \mathrm{AA}^{*}\right)\end{array}$ & 1,90 & 1,33 & 1,90 & 1,57 & 1,25 & 1,74 & 2,20 & 1,05 & 3,00 & 1,74 \\
\hline $\begin{array}{c}\text { Aldeídos em Aldeído Acético } \\
\left(\mathrm{mg} / 100 \mathrm{~mL} \text { de } \mathrm{AA}^{*}\right)\end{array}$ & 44,30 & 44,30 & 7,45 & 12,52 & 13,39 & 13,99 & 15,35 & 15,64 & 15,19 & 20,20 \\
\hline $\begin{array}{l}\text { Ésteres em Acetato de Etila } \\
\quad\left(\mathrm{mg} / 100 \mathrm{~mL} \text { de } \mathrm{AA}^{*}\right)\end{array}$ & 16,14 & 16,14 & 9,86 & 18,77 & 21,70 & 20,23 & 25,35 & 27,59 & 15,69 & 25,48 \\
\hline $\begin{array}{c}\text { Soma dos Componentes } \\
\text { Secundários }\left(\mathrm{mg} / 100 \mathrm{~mL} \text { de } \mathrm{AA}^{*}\right)\end{array}$ & 266,64 & 269,55 & 186,79 & 225,79 & 245,11 & 246,89 & 250,73 & 267,59 & 225,03 & 271,11 \\
\hline $\begin{array}{c}\text { Álcool Metílico } \\
(\mathrm{mg} / 100 \mathrm{~mL} \text { de } \mathrm{AA} *)\end{array}$ & 6,77 & 6,77 & 5,80 & 5,81 & 5,80 & 8,73 & 4,89 & 4,35 & 6,25 & 6,25 \\
\hline
\end{tabular}

\footnotetext{
${ }^{*} \mathrm{AA}=$ Álcool Anidro
} 
Os alambiques são, na sua maioria, constituídos de cobre, metal maleável, bom condutor de calor, resistente ao desgaste físico, e que apresenta grande influência na formação de sabor e aroma do produto (ROTA, 2008). Segundo Asquieri, Silva e Cândido (2009), o cobre reduz a acidez e os níveis de aldeídos e compostos sulfurosos que podem conferir sabor e odores estranhos à bebida.

A presença do cobre na aguardente tem sua origem na etapa de destilação, uma vez que o metal constituinte do equipamento, quando exposto ao ar úmido contendo gás carbônico lentamente se oxida, ficando coberto por uma camada esverdeada, chamada de "azinhavre", composta por $\mathrm{CuCO}_{3}$ e $\mathrm{Cu}(\mathrm{OH})_{2}$ (MARINHO; RODRIGUES; SIQUEIRA, 2009). Esta camada é então dissolvida pelos vapores alcoólicos ácidos, gerados durante o processo de destilação do vinho, o que resulta na contaminação do produto (BOZA; HORII, 2000; ASQUIERI; SILVA; CÂNDIDO, 2009).

A presença de cobre em elevadas concentrações na aguardente é altamente indesejável do ponto de vista da saúde, sendo, portanto, fundamental sua quantificação na bebida (CARDOSO, 2006).

$\mathrm{O}$ excesso de cobre pode ser tóxico ao consumidor, devido à afinidade do cobre com grupos S-H (grupo sulfidrila) de proteínas e enzimas (MARINHO; RODRIGUES; SIQUEIRA, 2009). Muitas enzimas contém esse grupo, que é essencial para suas atividades catalíticas normais, sendo que o cobre pode provocar a inativação dessas enzimas, aumentando a probabilidade de ocorrência do reflexo incondicional do organismo em rejeitar o cobre em forma de vômito (SARGENTELLI; MAURO; MASSABNI, 1996).

Altos níveis de cobre na bebida causam lesões em vasos capilares, fígado e rins, devido à formação do azinhavre, que é arrastado pelos vapores, contaminando o destilado (ASQUIERI; SILVA; CÂNDIDO, 2009). Sua presença em excesso no organismo (hipercupremia) está associada a várias doenças, como a epilepsia, melanoma e artrite reumatóide (SARGENTELLI; MAURO; MASSABNI, 1996). Esse excesso de cobre pode ser reduzido com a limpeza apropriada do alambique, bastando, para isso, fazer uma primeira destilação com água ou com água e caldo de limão, cujo vapor arrasta o azinhavre das paredes do alambique de cobre (LIMA et al., 2006).

Verifica-se também que, embora dentro dos limites estabelecidos pela legislação (BRASIL, 2005a; BRASIL, 2008), os teores de cobre, os valores de acidez volátil, álcool superior e soma dos componentes secundários foram superiores na aguardente obtida no alambique 2, o que se deve provavelmente a fatores como estado de conservação, "design", 
modo de operação, localização, sistema de resfriamento do capelo, dentre outros (Figuras 1 e 2).

No tocante a acidez volátil nota-se que a aguardente obtida nas diferentes bateladas, os teores se encontram abaixo do limite máximo estabelecido pela legislação brasileira (150 mg/100mL de AA para aguardente de cana e $100 \mathrm{mg} / 100 \mathrm{~mL}$ de AA para aguardente de frutas). Verifica-se que os valores obtidos no presente trabalho se encontram entre 23,74 e $34,69 \mathrm{mg} / 100 \mathrm{~mL}$ AA, os quais estão compatíveis com os encontrados em outros trabalhos onde foram reportados valores correspondentes a $30 \mathrm{mg} / 100 \mathrm{~mL}$ de AA para aguardente de jabuticaba (ASQUIERI; SILVA; CÂNDIDO, 2009); 33,195 mg/100mL de AA para aguardente de abacaxi (SILVA JÚNIOR et al., 2006) e 24,41 mg/100mL de AA para polpa de banana prata (SILVA et al., 2004).

Bogusz Junior et al. (2006) avaliaram a composição química da cachaça produzida na região noroeste do Rio Grande do Sul, onde as amostras das microrregiões de Cruz Alta e Santa Rosa apresentaram acidez volátil acima do máximo estabelecido na legislação (185,80 e 180,00 mg de ácido acético/100 mL de AA, respectivamente). Os autores sugerem que estes dados revelam falta de conhecimentos técnicos por parte dos produtores, pois, segundo Cardoso (2006), os teores de acidez volátil da cachaça dependem de fatores como o adequado controle do tempo e da temperatura durante o processo fermentativo, tipo de levedura utilizada, manejo do mosto e, principalmente, higiene no processo de fabricação.

De acordo com Lima (2001), o grau de acidez das cachaças constitui fator de qualidade, pois durante sua produção os ácidos reagem com os álcoois presentes e contribuem para formação de ésteres. Estes ésteres são importantes para o aroma, mas acidez em excesso promove sabor indesejado e agressivo, reduzindo a qualidade da bebida (JERONIMO et al., 2008). Deste modo, a acidez volátil é um importante parâmetro correlacionado às características sensoriais de bebidas alcoólicas destiladas (BOZA; HORII, 1998).

Acidez volátil em nível elevado é indicativo de contaminação microbiana advinda da falta de assepsia no processo e do não recolhimento da fração ideal do destilado (VARGAS; GLORIA, 1995), uma vez que a acidez é maior nas primeiras porções do destilado, diminuindo na parte intermediária e voltando a se elevar na metade final do coração e na cauda (JANZANTI, 2004; BOZA e HORII, 1998; FURTADO, 1995). 
Cardoso (2006) relata que deve-se evitar durante a fermentação a aeração do mosto, tendo em vista que o aumento de oxigênio favorece a produção de ácido acético. Uma vez terminada a fermentação, deve-se proceder à destilação o mais breve possível, a fim de evitar a proliferação de bactérias acéticas, que contribuem para o aumento da acidez.

No tocante a presença de álcoois superiores nos destilados alcoólicos, tem sido reportado que estes se apresentam em quantidades mínimas, como o isobutílico, amílico, propílico e isopropílico (ASQUIERI; SILVA; CÂNDIDO, 2009). Apresentam ação solvente sobre outras substâncias aromáticas interferindo no grau de volatilidade destas (BOZA; HORII, 1998). São álcoois com mais de dois átomos de carbono (BOGUSZ JUNIOR et al., 2006), resultantes do crescimento de leveduras e aproveitamento de aminoácidos como fonte de nutrientes amoniacais (MIRANDA; HORII; ALCARDE, 2006). São formados a partir da transaminação de certos aminoácidos ou da desaminação e descarboxilação de outros (BOZA; HORII, 1998; RIZZON et al., 1992).

Desta forma, no presente trabalho os valores da concentração de álcoois superiores apresentaram-se dentro do limite permitido pela Legislação Brasileira para aguardente de cana e de frutas $(360 \mathrm{mg} / 100 \mathrm{~mL}$ de AA), variando de 143,84 a 196,73 mg/100 mL de AA. Valores superiores foram encontrados por Asquieri, Silva e Cândido (2009), para aguardente de jabuticaba $(259,07 \mathrm{mg} / 100 \mathrm{~mL}$ de AA), por Parazzi et al. (2008) para aguardente de cana $(320,1 \mathrm{mg} / 100 \mathrm{~mL}$ de AA), por Silva et al. (2004) para aguardente de casca de banana $(434,1 \mathrm{mg} / 100 \mathrm{~mL}$ de AA) e por Miranda, Horii e Alcarde (2006) para aguardente de cana irradiada com raios gama, juntamente com o tonel $(426,58 \mathrm{mg} / 100 \mathrm{~mL}$ de AA).

Segundo Cardoso (2006), os álcoois com até cinco átomos de carbono apresentam odores característicos (buquê) tradicionalmente associados com bebidas destiladas, sendo responsáveis diretos pelo odor da bebida, conferindo aromas característicos, destacando-se os álcoois amílico e propílico, e seus respectivos isômeros. Com o aumento do número de carbonos, o aroma modifica-se substancialmente e os álcoois tornam-se oleosos. Alguns deles lembram fortemente o aroma de flores. O excesso de ácoois superiores interfere negativamente no valor comercial e na qualidade da aguardente. Semelhante ao metanol e etanol, esses álcoois também apresentam propriedades biológicas, sendo depressores do sistema nervoso central.

A quantidade de álcoois superiores formada é influenciada pela composição do mosto no que se refere a concentração de açúcar, $\mathrm{pH}$, concentração e tipo de fonte de nitrogênio, temperatura, grau de aeração durante a fermentação, a cepa da levedura, bem 
como pela concentração de aminoácidos, principalmente leucina (CLETO; MUTTON, 2004). A concentração destes compostos está diretamente relacionada com o tempo de fermentação. Assim, segundo Dantas et al. (2007), a formação de álcoois superiores é maior quando a fermentação for mais demorada, resultante da atividade de fermento mais fraco. Considerando que na maioria das unidades de produção de cachaça e aguardente não se observa um controle rigoroso das condições de processo, principalmente no tocante a pH e temperatura, é comum se verificar elevadas concentrações de álcoois superiores no produto final. Neste contexto, vale destacar que elevadas concentrações de álcoois superiores interferem negativamente na qualidade da bebida.

Cardoso (2006) e Masson (2005) relatam que a desidratação e a degradação térmica dos açúcares são reações de grande relevância nos alimentos; são catalisadas por ácidos ou bases e muitas são de $\beta$-eliminação, ou seja, ocorre a eliminação de moléculas ligadas ao carbono beta (MELLO, 2005). As pentoses, formam furfural como principal produto de degradação, já as hexoses formam 5-hidroximetilfurfural (HMF) e outros compostos como 2-hidroxiacetilfurano e isomaltol. A fragmentação da cadeia de carbono destes produtos primários de desidratação forma outros compostos, como ácido levulínico, ácido fórmico, acetol, acetoína e diacetilo e os ácidos lático pirúvico e acético. Alguns desses produtos de degradação apresentam odor intenso e podem conferir aromas tanto desejáveis como indesejáveis. Altas temperaturas de processo de fermentação induzem tais reações, sendo que furfural e 5-hidroximetilfurfural foram encontrados em sucos de frutas processadas termicamente (CARDOSO, 2006) Assim, destaca-se o trabalho realizado Aquino et al. (2004), onde foi detectado a presença de furfural e HMF em amostras de cajuína, bebida típica do nordeste brasileiro preparada a partir do suco de caju e por Brasil, Maia e Figueiredo (1995), na produção de suco clarificado de goiaba.

Neste contexto, observa-se no presente trabalho (Tabela 11), que o teor de furfural obtido na aguardente avaliada variou de 1,05 a 3,00 mg/100mL de AA, valores estes superiores aos obtidos em outros trabalhos, porém abaixo do valor máximo estabelecido pela legislação brasileira para aguardente de cana e de fruta, que é de $5 \mathrm{mg} / 100 \mathrm{~mL}$ de AA. Dantas et al. (2007) encontraram valores que variaram de 0,13 a $0,56 \mathrm{mg} / 100 \mathrm{~mL}$ de AA em aguardente de cana de açúcar. Masson et al. (2007) ao estudarem os parâmetros fisicoquímicos e cromatográficos em aguardentes de cana queimada e não queimada, encontram valores de furfural que variaram de 0,63 a $8,80 \mathrm{mg} / 100 \mathrm{~mL}$ de $\mathrm{AA}$. Na aguardente de 
jabuticaba não foi detectada a presença de furfural (ASQUIERI; SILVA; CÂNDIDO, 2009).

Segundo Masson (2005), o furfural, um aldeído de presença rara em algumas aguardentes, é resultante da decomposição química de carboidratos. É formado, principalmente, pela pirogenação da matéria orgânica depositada no fundo dos alambiques, e a sua formação é evitada pela destilação do vinho limpo, livre de substâncias orgânicas em suspensão.

O furfural contribui para o sabor ardente da bebida e pode ser oriundo da madeira, no caso de aguardentes envelhecidas, ou da destilação, como produto da desidratação ou degradação térmica do açúcar residual durante o aquecimento prolongado no alambique (ASQUIERI; SILVA; CÂNDIDO, 2009). Desta forma, vale destacar a importância da filtração do mosto, do consumo de mais de $80 \%$ do açúcar inicial por parte da levedura $\mathrm{T}$, bem como a decantação prévia do vinho a ser destilado, o que explica os baixos teores de furfural observados no presente trabalho.

Os açúcares residuais e os compostos sulfurados podem sofrer transformações químicas durante o aquecimento do vinho, no alambique, afetando a qualidade da bebida (CARDOSO, 2006). A presença de açúcares residuais ou bagacilho (no caso da cana de açúcar) no vinho poderá formar compostos indesejáveis, catalisados pelo aumento da temperatura e pelo $\mathrm{pH}$ ácido do vinho, desidratando os açúcares e hidrolisando celulose, hemicelulose e pectina, como também outros polissacarídeos do bagacilho, seguido da desidratação dos monômeros de pentoses e hexoses, originando furfural e HMF, respectivamente $\left(\mathrm{MAIA}^{2}, 1994\right.$ apud MASSOM, 2005, p. 18). Destilação à temperatura controlada previne a formação do furfural (DANTAS et al., 2007).

De acordo com Cardoso (2006), os aldeídos presentes nas bebidas alcoólicas podem ter sua origem na ação das leveduras durante estágios preliminares do processo de fermantação, principalmente o acetaldeído, que tende a desaparecer no final, pela oxidação a ácido acético. Este autor salienta que são compostos voláteis, de odores penetrantes, afetando o aroma das bebidas alcoólicas. São co-produtos que antecedem a formação dos álcoois (MASSON, 2005), formados pela descarboxilação de oxoácidos, ou então, pela oxidação dos respectivos álcoois, como ocorre com o furfural e HMF (CARDOSO, 2006).

\footnotetext{
${ }^{2}$ MAIA, A. B. Componentes Secundários da Aguardente. STAB, Piracicaba, v.12, n. 6, p. 29-34, jul./ago. 1994.
} 
No tocante a presença de aldeídos nas bebidas destiladas Dantas et al (2007) afirmam que este composto em excesso é extremamente indesejável para uma aguardente de qualidade. De acordo com Braga (2006), os aldeídos com até oito átomos de carbono apresentam aromas penetrantes, geralmente enjoativos, considerados indesejáveis, sendo que os aldeídos que contêm acima de dez átomos de carbono na molécula conferem aroma agradável à bebida. Desta forma, verifica-se (Tabela 11) que a concentração de aldeído acético para o destilado obtido nos 2 alambiques, na primeira batelada, foi de 44,30 $\mathrm{mg} / 100 \mathrm{~mL}$ de AA, portanto acima do limite estabelecido pela legislação brasileira pra aguardente de cana e fruta, que é de $30,0 \mathrm{mg} / 100 \mathrm{~mL}$ AA. Por outro lado, verifica-se que nas bateladas seguintes a concentração de aldeído acético, nas respectivas aguardentes, se manteve em níveis abaixo do estabelecido pela legislação (BRASIL, 2005a; BRASIL, 2008).

O elevado teor de aldeído nas aguardentes obtidas no presente trabalho, nos dois alambiques, na primeira batelada, se deve provavelmente, a deficiências observadas na separação da fração "cabeça", uma vez que compostos mais voláteis que o etanol, representados por ésteres e aldeídos, são mais frequentes na fração cabeça (MASSON et al., 2007; FERNANDES et al., 2007). Na elaboração da aguardente de mel, as frações "cabeça" e "cauda" foram descartadas, onde somente a fração "coração" foi armazenada em tonel de carvalho.

Valores semelhantes aos obtidos no presente trabalho foram reportados por Asquieri, Silva e Cândido (2009), que obtiveram 13,60 mg/mL de AA em aguardente de jabuticaba e por Bizelli, Ribeiro e Novaes (2000), que encontraram 15,80 mg/100 mL de AA em aguardente de cana obtida por dupla destilação e $21,11 \mathrm{mg} / 100 \mathrm{~mL}$ de AA em aguardente de cana obtida por destilação convencional. O teor mais elevado de aldeído na aguardente obtida por destilação convencional se deve provavelmente ao processo utilizado pelos autores na obtenção dos destilados pois, na obtenção da aguardente monodesilada, não se procedeu a separação da fração "cabeça", onde os ésteres estão presentes em maior proporção devido ao seu ponto de ebulição. Por outro lado, na aguardente bidestilada, foi realizado o fracionamento do destilado em frações denominadas "cabeça", "coração" e "cauda", obtendo deste modo uma aguardente com menor teor destes compostos.

Valores elevados de aldeído foram encontrados em aguardente de uva e laranja, correspondendo a 58,6 mg/100 mL de AA e $86,2 \mathrm{mg} / 100 \mathrm{~mL}$ de AA, respectivamente (CLETO; MUTTON, 2004). Os autores sugerem que a matéria-prima influi na composição 
da aguardente pois, o vinho obtido a partir de uva e laranja apresentaram-se bastante ácidos (4,0 e 6,1 $\left.\mathrm{g} \mathrm{H}_{2} \mathrm{SO}_{4} / \mathrm{L}\right)$, o que favoreceu a oxidação do etanol à acetaldeído. Para cachaça submetida à irradiação gama, juntamente com o tonel, concentração de aldeído acético de $42,07 \mathrm{mg} / 100 \mathrm{~mL}$ de AA foi reportado por Miranda, Horri e Alcarde (2006), sendo neste caso, o elevado teor de aldeído atribuído à irradiação da madeira, que favoreceu a reação de oxidação de etanol na formação de acetaldeído possivelmente pela exposição de maior superfície de contato nestes tonéis.

A intoxicação por aldeídos pode levar a sérios problemas associados com o sistema nervoso central (CARDOSO, 2006), estando relacionado à intoxicação e sintomas de "ressaca": náusea, vômitos, inquietação, sudorese, convulsão, queda da pressão sangüínea, aceleração dos batimentos cardíacos e dores de cabeça (NASCIMENTO et al., 1997).

A concentração de células de leveduras no vinho a ser destilado influi na composição química, no aroma e no corpo dos destilados, pois estas enriquecem os destilados principalmente com ésteres e com aminoácidos (MASSON, 2005).

Os ésteres podem ser oriundos da reação de esterificação entre um ácido e um álcool (MASSON, 2005). Segundo Janzanti (2004), a maior parte dos ésteres é constituída por ésteres de etila, formados por reações enzimáticas resultantes do metabolismo da levedura durante a fermentação e que são destilados juntamente com o etanol. Estas reações ocorrem porque o etanol pode reagir com ácidos derivados do ácido pirúvico, como ácido láctico e acético, bem como outros ácidos orgânicos tais como butírico, capróico, caprílico, cáprico e láurico.

O acetato de etila normalmente é o éster predominante nas bebidas alcoólicas, e no caso das cachaças corresponde à cerca de $80 \%$ do conteúdo total de ésteres, produto da reação de esterificação entre etanol e ácido acético (JANZANTI, 2004). Este éster, em pequenas quantidades, incorpora um aroma agradável de frutas (BRAGA, 2006; CARDOSO, 2006; MASSON, 2005). Dentre outros ésteres de importância destacam-se acetato de isoamila (aroma de pêra), acetato de isobutila (aroma de banana), acetato de 2feniletil (aroma de mel, frutado, flores) e caproato de etila (aroma de maçã) (PEDDIE, 1990).

Em relação aos ésteres, resultantes de reações químicas ocorridas durante a fermentação (ASQUIERI; SILVA; CÂNDIDO, 2009), observa-se que as amostras de aguardente de mel obtidas no presente trabalho apresentaram valores que variaram de 9,86 a $27,59 \mathrm{mg} / 100 \mathrm{~mL}$ de AA, portanto abaixo do limite máximo estabelecido pela legislação 
brasileira para aguardente de cana e de frutas, que corresponde a 200 e $250 \mathrm{mg} / 100 \mathrm{~mL}$ de AA respectivamente (BRASIL, 2005a; BRASIL, 2008). Valores semelhantes foram encontrados por Bizelli, Ribeiro e Novaes (2000), onde a aguardente de cana proveniente da destilação convencional apresentou um valor de $20 \mathrm{mg} / 100 \mathrm{~mL}$ de AA e por Martínez et al. (1997), que obtiveram valores que oscilaram entre 4,6 e 19,4 mg/100 mL de AA também para aguardente de cana.

Hernández-Gómez, Úbeda e Briones (2003), reportaram valores de concentração de ésteres que variaram de 4,08 a 15,4 mg/100 mL de AA para aguardente de melão e em aguardentes produzidas com banana prata integral e casca de banana, estes valores corresponderam a 21,40 e 17,33 mg/100 mL de AA, respectivamente (SILVA et al., 2004). Por outro lado, valor bastante superior (357 mg/100 mL de AA) foi encontrado por Asquieri, Silva e Cândido (2009) na produção de aguardente de jabuticaba,. Os autores sugerem que este elevado teor de éster se deve a falhas no recolhimento da fração "cabeça" e ressaltam ainda que o modo de destilação praticado (destilação lenta) e a presença de células de leveduras no vinho também podem ter influenciado.

De acordo com Janzanti (2004) alguns dos fatores que influenciam a formação de ésteres são: tipo e quantidade de levedura, tendo em vista que cada cepa de levedura apresenta um perfil de produção de éster característico podendo variar na quantidade e no tipo de ésteres (PEDDIE, 1990); além da temperatura de fermentação; aeração; agitação e a qualidade do mosto.

Em relação à qualidade do mosto, destaca-se a falta de nutrientes como por exemplo o nitrogênio, que segundo Berry e Slaughter (2003) pode estimular a formação de ésteres. Esses autores afirmam que em condições de anaerobiose estrita a formação da membrana celular é influenciada negativamente e, nessas condições, ácidos orgânicos tornam-se disponíveis para conversão em ésteres, que são excretados para o meio.

A quantidade de ésteres é dependente da abundância relativa dos álcoois correspondentes e radicais acil-CoA (envolvidos no metabolismo de ácidos graxos) produzidos pelas leveduras, em que o acetil CoA é o mais comum, o qual é formado pela descarboxilação oxidativa do piruvato e tem papel central no metabolismo das leveduras (JANZANTI, 2004).

Segundo Berry e Slaughter (2003) a maioria dos ésteres é produzida nos últimos estágios de fermentação, ao contrário dos álcoois superiores, que são produzidos abundantemente no início. Alguns autores relatam que o tipo e a forma de operação do destilador são fundamentais para se ter a concentração adequada de ésteres no destilado 
(MASSON, 2005; BOGUSZ JUNIOR et al, 2006). O teor de ésteres também pode ser controlado por meio do uso de substratos adequados, controle do tempo de fermentação e recolhimento da fração ideal do destilado (VARGAS; GLORIA, 1995).

Concentrações elevadas de ésteres podem interferir negativamente na qualidade do destilado, conferindo-lhe um sabor enjoativo e desagradável (LIMA et al., 2006).

De acordo com Cardoso (2006) o desenvolvimento da fermentação alcoólica passa pelo desdobramento dos açúcares do mosto com formação de dois produtos principais: álcool etílico e dióxido de carbono. Além desses, há normalmente a formação de pequenas quantidades de outros componentes, os quais recebem a denominação de produtos secundários da fermentação alcoólica. Esses compostos vão conferir, nas diferentes aguardentes, características peculiares, definidas como o "flavour" da bebida (MASSON, 2005), sendo portanto, os determinantes de sua qualidade (JANZANTI, 2004). Os compostos secundários, por serem encontrados em pequenas quantidades, são difíceis de serem determinados, bem como quantificados (MASSON, 2005).

Segundo o Decreto $\mathrm{n}^{\circ} 6871$ - MAPA (BRASIL, 2009), entende-se como componentes secundários dos destilados, a soma da acidez volátil, e concentração (mg/100 AA) de aldeídos (acetaldeído), ésteres (acetato de etila), álcoois superiores (expressos pelo seu somatório), e furfural, sendo estabelelcidos para aguardente de cana e de frutas valores entre 200 e $650 \mathrm{mg} / 100 \mathrm{~mL}$ de AA. Neste sentido, verifica-se (Tabela 11) que a aguardente obtida no alambique 1, na segunda batelada, apresentou uma soma dos componentes secundários inferior a este limite $(186,79 \mathrm{mg} / 100 \mathrm{~mL}$ de AA), sendo desta maneira classificada como fora de padrão. Porém, nas demais bateladas a referida aguardente apresentou valores dentro dos padrões estabelecidos pela referida legislação.

Os valores da soma dos componentes secundários obtidos no presente trabalho, variaram de 186,79 a $271,11 \mathrm{mg} / 100 \mathrm{~mL}$ de AA, valores estes abaixo dos obtidos em outros trabalhos. A aguardente de jabuticaba obtida por Asquieri, Silva e Cândido (2009), pelo fato de apresentar um alto teor de ésteres, que é um dos componentes secundários, apresentou também um elevado valor para a soma dos componentes secundários $(659,67$ $\mathrm{mg} / 100 \mathrm{~mL}$ de AA), valor este acima do permitido pela legislação. O valor encontrado por Miranda, Horii e Alcarde (2006) para cachaça submetida à irradiação gama, juntamente com o tonel, foi de $583,02 \mathrm{mg} / 100 \mathrm{~mL}$ de AA. 
No tocante a presença de metanol nos destilados pode-se afirmar que este é um álcool particularmente indesejável. Este álcool é resultante da degradação da pectina, que é um polissacarídeo presente na cana-de-açúcar, sendo formado pela associação de centenas de moléculas de ácido galacturônico, que apresentam moléculas de metanol em sua estrutura (CARDOSO, 2006). Durante o processo de fermentação do mosto, o metanol é liberado, por meio de hidrólise, das moléculas do ácido galacturônico (MASSON, 2005).

No presente trabalho observa-se (Tabela 11) que os teores de metanol encontrados variaram de 4,35 a $8,73 \mathrm{mg} / 100 \mathrm{~mL}$ de AA, valores estes dentro dos padrões preconizados pela legislação brasileira, que é de $20 \mathrm{mg} / 100 \mathrm{~mL}$ de AA (BRASIL, 2005a; BRASIL, 2008).

Valores superiores foram encontrados por Bizelli, Ribeiro e Novaes (2000) para aguardente de cana obtida por destilação convencional e dupla destilação, correspondendo a 17,36 e $14,13 \mathrm{mg}$ de metanol/100mL de AA, respectivamente, sendo que Alves et al. (2008), reportaram para aguardente de goibada teor de metanol de $62 \mathrm{mg} / 100 \mathrm{~mL}$ de AA. Os autores justificam o elevado teor de álcool metílico encontrado na aguardente de goiaba devido a ação da pectinase, a qual foi empregada para facilitar a extração da polpa de goiaba e diminuir a sua viscosidade. Resultados semelhantes foram obtidos por Asquieri, Silva e Cândido (2009), que encontraram teor de 4,30 mg/100mL de AA para aguardente de jabuticaba, sendo que Miranda, Horii e Alcarde (2006) obtiveram valores de metanol que variaram de 6,84 a $8,83 \mathrm{mg} / 100 \mathrm{~mL}$ de AA em aguardente de cana submetida a diferentes tratamentos de irradiação com raios gama.

No que se refere a presença de metanol em bebidas destiladas a literatura reporta que este composto ocorre naturalmente como produto secundário no processo de fermentação, em pequenas quantidades, não oferecendo risco à saúde do consumidor (ARRUDA, 2006). O metanol no organismo humano é oxidado a ácido fórmico e posteriormente a $\mathrm{CO}_{2}$, provocando uma acidose grave que resulta em redução do $\mathrm{pH}$ sanguíneo, afetando o sistema respiratório, podendo levar ao coma e até mesmo à morte (CARDOSO, 2006; BOGUSZ JUNIOR et al., 2006; HSDB, 1994). Sua ingestão, mesmo em quantidades reduzidas, por longos períodos de consumo, pode ocasionar cegueira e até mesmo a morte (HSDB, 1994; WINDHOLZ, 1976).

$\mathrm{Na}$ aguardente de cana, o metanol é formado principalmente quando não se tem o cuidado de separar, por filtragem, os fragmentos da cana-de-açúcar (bagacilho) que se originam no momento da moagem ou passagem pela prensa, pois estes fragmentos são 
ricos em pectina (BOGUSZ JUNIOR et al., 2006). Nos destilados alcoólicos de frutas, principalmente aqueles que são submetidas ao processo de prensagem, o teor de metanol encontrado é maior, porque substâncias pécticas presentes nas frutas sofrem degradação pela ação de enzimas, principalmente as pectina-metilestereases, liberando metanol (ASQUIERI; SILVA; CÂNDIDO, 2009).

No presente trabalho a fração "coração" de cada batelada foi devidamente caracterizada (Tabela 11) e transferidas para um tonel de carvalho até se completar o volume de 200 litros, sendo este considerado o tempo inicial. Em seguida a cada 30 dias amostras foram coletadas para a devida caracterização físico química e sensorial, cujos resultados encontram-se apresentados nas Tabelas 12 e 13.

As mudanças nas características sensoriais de bebidas alcoólicas na fase de descanso ou envelhecidas em tonéis de madeira, são decorrentes da variação da composição química da bebida, resultantes de reações químicas entre os compostos contidos na bebida e/ou com os componentes da madeira da qual o tonel é construído (JANZANTI, 2004).

Inúmeras transformações químicas estão associadas ao processo de maturação e envelhecimento da aguardente como por exemplo, a oxidação de álcoois em aldeídos; a oxidação de aldeídos em ácidos, a degradação de lignina por etanólise formando aldeídos aromáticos; e a reações de esterificação entre ácidos e álcoois formando os ésteres, responsáveis pelo sabor agradável e característico das bebidas envelhecidas (REAZIN, 1981).

Segundo Parazzi et al., (2008) e Miranda et al., (2008), durante a maturação de bebidas destiladas, normalmente ocorre uma diminuição do $\mathrm{pH}$ e das concentrações de cobre, álcool metílico e álcool etílico, enquanto se observam aumentos da acidez, cor e das concentrações de ésteres, aldeídos, furfural, álcoois superiores, coeficiente de congêneres e compostos fenólicos

Durante o envelhecimento em barril de madeira observa-se um aumento progressivo no teor de extrato seco, no qual os taninos e os compostos fenólicos chegam a representar até 40\% (CARDOSO, 2006). O aumento do teor de extrato seco na aguardente ocorre em função da degradação da lignina pelo etanol em compostos aromáticos, como a vanilina, siringaldeído, coniferaldeído e sinapaldeído (CATÃO et al., 2011; MIRANDA et al., 2008). 
Tabela 12 - Caracterização Físico Química da Aguardente de mel em diferentes tempos de descanso em tonel de carvalho.

\begin{tabular}{|c|c|c|c|c|c|c|c|c|c|c|c|}
\hline \multirow[b]{3}{*}{ Análises } & \multirow{2}{*}{\multicolumn{7}{|c|}{ Tempo de descanso em dias }} & \multicolumn{4}{|c|}{ Limites Legislação } \\
\hline & & & & & & & & \multicolumn{2}{|c|}{$\begin{array}{l}\text { Aguardente } \\
\text { de cana** }\end{array}$} & \multicolumn{2}{|c|}{$\begin{array}{l}\text { Aguardente } \\
\text { de Fruta*** }\end{array}$} \\
\hline & $\mathbf{0}$ & 30 & 60 & 90 & 120 & 150 & 180 & Mín. & Máx. & Mín. & Máx. \\
\hline $\begin{array}{l}\text { Densidade Relativa } \\
\left(20 / 20^{\circ} \mathrm{C}\right)\end{array}$ & 0,94280 & 0,94367 & 0,94347 & 0,94310 & 0,94310 & 0,94197 & 0,94182 & - & - & - & - \\
\hline $\begin{array}{c}\text { Cobre } \\
(\mathrm{mg} / \mathrm{L})\end{array}$ & 2,49 & 1,11 & 1,05 & 1,36 & 1,39 & 1,56 & 1,76 & - & 5,00 & - & 5,00 \\
\hline $\begin{array}{c}\text { Extrato Seco a } 100^{\circ} \mathrm{C} \\
(\mathrm{g} / \mathrm{L})\end{array}$ & 0,060 & 0,080 & 0,104 & 0,112 & 0,116 & 0,236 & 0,236 & - & - & - & - \\
\hline $\begin{array}{c}\text { Grau Alcoólico Real a } 20^{\circ} \mathrm{C} \\
(\% \mathrm{~V} / \mathrm{V})\end{array}$ & 44,07 & 43,59 & 43,69 & 43,91 & 43,91 & 44,53 & 44,63 & 38,0 & 54,0 & 36,0 & 54,0 \\
\hline $\begin{array}{l}\text { Acidez Volátil em Ácido Acético } \\
\left(\mathrm{mg} / 100 \mathrm{~mL} \text { de } \mathrm{AA}^{*}\right)\end{array}$ & 30,62 & 44,71 & 48,04 & 47,30 & 50,67 & 53,30 & 56,51 & - & 150,0 & - & 100,0 \\
\hline $\begin{array}{c}\text { Álcool Superior } \\
\left(\mathrm{mg} / 100 \mathrm{~mL} \text { de } \mathrm{AA}^{*}\right)\end{array}$ & 177,82 & 173,81 & 201,59 & 180,25 & 172,28 & 178,50 & 179,86 & - & 360,0 & - & 360,0 \\
\hline $\begin{array}{c}\text { Furfural } \\
\left(\mathrm{mg} / 100 \mathrm{~mL} \text { de } \mathrm{AA}^{*}\right)\end{array}$ & 1,76 & 1,71 & 2,12 & 2,14 & 2,23 & 2,66 & 2,70 & - & 5,0 & - & 5,0 \\
\hline $\begin{array}{l}\text { Aldeídos em Aldeído Acético } \\
\left(\mathrm{mg} / 100 \mathrm{~mL} \text { de } \mathrm{AA}^{*}\right)\end{array}$ & 20,01 & 19,89 & 20,73 & 20,37 & 20,62 & 20,83 & 21,28 & - & 30,0 & - & 30,0 \\
\hline $\begin{array}{l}\text { Ésteres em Acetato de Etila } \\
\quad\left(\mathrm{mg} / 100 \mathrm{~mL} \text { de } \mathrm{AA}^{*}\right)\end{array}$ & 25,73 & 27,01 & 27,95 & 24,10 & 26,10 & 27,72 & 27,66 & - & 200,0 & - & 250,0 \\
\hline $\begin{array}{c}\text { Soma dos Componentes } \\
\left.\text { Secundários (mg/100mL de } \mathrm{AA}^{*}\right)\end{array}$ & 255,94 & 267,13 & 300,43 & 274,16 & 271,90 & 283,01 & 288,01 & 200,0 & 650,0 & 200,0 & 650,0 \\
\hline $\begin{array}{c}\text { Álcool Metílico } \\
(\mathrm{mg} / 100 \mathrm{~mL} \text { de AA*) }\end{array}$ & 5,82 & 6,12 & 6,11 & 13,22 & 9,12 & 11,47 & 10,07 & - & 20,0 & - & 20,0 \\
\hline
\end{tabular}

${ }^{*} \mathrm{AA}=$ Álcool Anidro

** BRASIL, 2005a

*** BRASIL, 2008 
Desta forma, no presente trabalho observa-se (Tabela 12) que os valores de extrato seco obtidos ao longo dos seis meses de armazenamento da aguardente de mel variaram de 0,060 g/L (tempo inicial) a 0,236 g/L (180 dias) devido a formação de compostos resultantes de reações químicas e a transferência dos componentes solúveis da madeira para a aguardente (SILVA; VASCONCELOS, 2009). Miranda, Horii e Alcarde (2006), encontraram valores de teor de extrato seco variando de 1,72 a $1,80 \mathrm{~g} / \mathrm{L}$ em cachaças submetidas a diferentes tratamentos com irradiação gama, e envelhecidas por um período de 390 dias. Miranda et al. (2006), ao estudarem o perfil fisíco-químico de aguardente durante envelhecimento em tonéis de carvalho, obtiveram um teor de extrato seco de 1,76 $\mathrm{g} / \mathrm{L}$ ao final de 390 dias.

Catão et al. (2011) ao avaliarem a qualidade da madeira de cinco espécies florestais no envelhecimento de cachaça, e comparar os resultados obtidos com cachaças armazenadas em barril de carvalho, encontraram valores de extato seco que variaram de 0,906 a 1,526 g/L para as cachaças armazendas em carvalho, no perído de 2 meses e 6 meses respectivamente. Para as cachaças armazenadas em amburama por exemplo, o teor de extrato seco variou de $0,017 \mathrm{~g} / 1$ (2 meses) a $0,300 \mathrm{~g} / \mathrm{L}$ (6 meses).

Durante a maturação da aguardente em barril de madeira, ocorre um considerável aumento na concentração de aldeídos, ésteres e ácidos totais, sendo que os dois primeiros aumentam linearmente e o último mais rapidamente no início da maturação (CARDOSO, 2006). Observou-se no presente trabalho (Tabela 12), que a concentração de aldeídos e ésteres permaneceram praticamente constantes, ao passo que a acidez volátil aumentou de $30,62 \mathrm{mg} / 100 \mathrm{~mL}$ de AA para $56,51 \mathrm{mg} / 100 \mathrm{~mL}$ de AA ao longo dos 180 dias de descanso

A acidez total de uma aguardente eleva-se com o envelhecimento, em decorrência do aumento da acidez volátil ao longo do armazenamento, provavelmente pela elevação do teor de ácido acético, formado por oxidação (LIMA, 1999; REAZIN, 1981). Além disso, conforme reportado por Miranda et al. (2008) alguns compostos oriundos da madeira, como ácidos orgânicos não voláteis, componentes secundários, como taninos e compostos fenólicos, favorecem o aumento da acidez da cachaça em envelhecimento.

Neste contexto, observa-se (Tabela 12) no presente trabalho um aumento da acidez volátil da aguardente de mel que variou de $30,62 \mathrm{mg} / 100 \mathrm{~mL}$ de AA a 56,51 mg/100 mL de AA, do tempo inicial a 180 dias de armazenamento em barril de carvalho, permanecendo 
dentro do limite estabelelcido pela legislação brasilareira para aguardente de cana (BRASIL, 2005a) e de frutas (BRASIL, 2008), que é de 150,0 e 100,0 mg/100mL de AA respectivamente.

Este aumento da acidez volátil também foi observado por Catão et al. (2011) durante o período de armazenamento das cachaças em barris elaborados a partir de diferentes tipos de madeiras. Os valores encontrados pelos autores ao final de 6 meses de armazenamento em barris de $20 \mathrm{~L}$ foi de $33,70 \mathrm{mg} / 100 \mathrm{~mL}$ de AA para aguardente armazenada em barril de jatobá, $65,00 \mathrm{mg} / 100 \mathrm{~mL}$ de AA para barril de jequitibá e 57,80 mg/100 mL de AA para barril de carvalho. Miranda et al. (2008), encontraram valores de acidez ao final de 390 dias de envelhecimento em tonel de carvalho, equivalente a 83,14 $\mathrm{mg} / 100 \mathrm{~mL}$ de AA contra um valor inicial de $8,17 \mathrm{mg} / 100 \mathrm{~mL}$ de AA.

Verifica-se também que a densidade relativa, o teor de cobre e o teor alcoólico da aguardente de mel mantiveram-se praticamente inalterados durantes os 180 dias de armazenamento em tonel de carvalho, sendo estes valores mantidos dentro dos limites preconizados pela legislação brasileira.

Miranda et al. (2008) também não observaram grande variação no teor alcoólico de aguardentes de cana envelhecidas em tonel de carvalho no período de 390 dias. O teor de cobre em aguardente de cana apresentou um leve declínio ao longo de diferentes períodos de armazenamento em trabalhos realizados por Catão et al. (2011) - 6 meses; Miranda et. al. (2008) - 390 dias e Alcarde, Souza e Belluco (2010) - 3 anos.

Apesar de ser formado, principalmente, durante a destilação do vinho, a concentração de furfural tende a aumentar durante o período de maturação de bebidas destiladas devido à degradação de pentoses e seus polímeros (hemicelulose) presentes na madeira do tonel (EGOROV; RODOPULO, 1994; ANJOS et al., 2010).

Desta forma, no presente trabalho observou-se um pequeno aumento no teor de furfural na aguardente armazenada, variando de 1,76 a 2,70 mg/100mL de AA no período de 180 dias, estando estes valores dentro do limite máximo permitido pela Legislação Brasileira (BRASIL, 2005a; BRASIL, 2008).

Um aumento no teor de furfural também foi observado por Catão et al. (2011), onde maiores teores foram encontrados em aguardente armazenada em barril de jequitibá $(0,962 \mathrm{mg} / 100 \mathrm{~mL}$ de AA) e carvalho $(0,948 \mathrm{mg} / 100 \mathrm{~mL}$ de AA $)$; por Miranda et al. (2008), onde o teor observado foi de $1,14 \mathrm{mg} / 100 \mathrm{~mL}$ de AA após 390 dias de 
envelhecimento. Alcarde, Souza e Belluco (2010), encontraram 0,46 mg/100mL de AA) em aguardentes armazendas em tonéis de Ipê-roxo

Durante o envelhecimento a quantidade de aldeídos eleva-se, porque são produtos intermediários da oxidação do álcool, mas sua elevação não obedece a uma proporcionalidade definida (LIMA, 1999). O acetaldeído representa a maioria dos aldeídos presentes, sendo o resultado da oxidação do álcool etílico (CARDOSO, 2006).

Dentre as reações químicas mais importantes que ocorrem durante a maturação e que altera a composição da bebida, se destacam a oxidação e a formação de acetal (MIRANDA et al., 2008), como a formação de acetaldeído e ácido acético a partir do álcool etílico (REAZIN, 1981).

O equilíbrio acetaldeído/hemiacetal é estabelecido para a maioria dos aldeídos, onde o acetaldeído reage com etanol (reação de adição), formando um hemiacetal, o qual irá reagir com outra molécula de etanol (condensação) resultando na formação de 1,1dietoxi-etano, que apresenta características de odor reportadas como "refrescante", "frutado" e "verde", contribuindo para o aroma final da aguardente, tanto pela redução do odor pungente e desagradável do aldeído predominante na bebida (acetaldeído) quanto pelo provimento das características de aroma citadas (NÓBREGA, 2003; PIGGOTT; CONNER, 2003). O equilíbrio entre aldeídos livres, hemiacetal e acetal, é influenciado pelo pH e pela concentração de álcool etílico (PIGGOTT; CONNER, 2003) e também pelo tipo de madeira do tonel (MIRANDA et al., 2008).

No presente trabalho a concentração de aldeídos praticamente não sofreu variação durante o período de descanso em tonel de madeira ao longo dos 180 dias. Isto se deve provavelmente ao fato que este período foi insuficiente para que reações de oxidação tivessem ocorrido. Por outro lado, Catão et al. (2011) observaram um aumento do teor de aldeído ao longo dos 180 dias de armazenamento do destilado de cana-de-açúcar armazenado em amburana $(5,3 \mathrm{mg} / 100 \mathrm{~mL}$ de AA), Ipê $(31,6 \mathrm{mg} / 100 \mathrm{~mL}$ de AA), Jatobá $(30,2 \mathrm{mg} / 100 \mathrm{~mL}$ de AA) e carvalho $(2,2 \mathrm{mg} / 100 \mathrm{~mL}$ de AA), partindo de um controle com 1,5 mg/100mL de AA. Aumento de $125 \%$ no teor de aldeídos (de 12,63 mg/100mL de AA para 28,41 mg/100mL de AA) foi observado por Miranda et al. (2008) ao longo de 390 dias de envelhecimento do destilado de cana. 
O metanol é um dos compostos voláteis, que tem merecido particular atenção devido à sua toxicidade, tratando-se de uma substância neurotóxica para o ser humano, que afeta especialmente a retina (MOTA et al., 2010).

O teor de metanol encontrado na aguardente de mel obtida no presente trabalho, armazenada por 6 meses em tonel de carvalho, apresentou pequena variação, porém permanecendo dentro do limite estabelecido pela Legislação Brasileira (BRASIL, 2005a; BRASIL, 2008). A diferença nos valores obtidos deve-se provavelmente à sensibilidade do método utilizado na identificação deste composto (BRASIL, 2005b), uma vez que o metanol é originado da degradação da pectina durante a fermentação, e a sua concentração não deve ser influenciada no período de descanso.

Catão et al. (2011) e Miranda et al. (2008) também não detectaram variação no teor de metanol durante o período de armazenamento, que foi de 6 meses e 390 dias respectivamente, dos destilados de cana. Por outro lado, Anjos et al. (2010) observaram um aumento na concentração de metanol durante o período de maturação da cachaça por 12 meses.

No tocante a presença de álcoois superiores Lima (1999) reportou que é comum nas aguardentes e seu teor é elevado, sobretudo quando o produto é obtido em alambiques operados na modalidade "bica corrida", sendo que a sua concentração não apresenta alterações significativas durante o envelhecimento e um ligeiro aumento está relacionado com a redução da graduação alcoólica durante o armazenamento.

As concentrações de álcoois superiores obtidas no presente trabalho, não apresentaram grandes variações durante o período de armazenamento, permanecendo dentro dos limites estabelecidos pela Legislação Brasileira (BRASIL, 2005a; BRASIL, 2008), observando-se teor de 179,86 mg/100mL de AA após 180 dias de descanso. No entanto, Miranda et al. (2008) observaram um ligeiro acréscimo (13\%) no teor de álcoois superiores ao longo dos 360 dias de envelhecimento de aguardente de cana, atingindo valor de $354,29 \mathrm{mg} / \mathrm{mL}$ de AA. Téo et al. (2005) ao avaliarem a composição de aguardentes de cana produzidas em duas unidades industriais e envelhecidas em barris de 200 litros de carvalho, amburana, bálsamo e jequitibá por 22 meses, observaram aumentos acentuados nos teores de álcool superior nas bebidas provenientes de ambas as unidades de produção e em todos os barris avaliados. Observaram também que as aguardentes armazenadas em bálsamo e amburana apresentaram as maiores concentrações (671 e 627 mg/100mL de AA, respectivamente), as quais estão bem acima das concentrações preconizadas pela legislação 
(360 mg/100mL de AA). Os autores sugerem que este aumento está relacionado com a perda de volume por evaporação, durante o armazenamento, uma vez que os vapores que se perdem são constituídos principalmente de água e álcool. No Brasil são comuns perdas de água e de álcool de 3 a 4\% ao ano, seja pela qualidade dos tonéis utilizados ou pela idade das madeiras em uso (CATÃO et al., 2010). Em ambiente de baixa umidade relativa a perda de água é favorecida enquanto a alta umidade favorece a perda de álcool através dos tonéis (NICOL, 2003).

De acordo com Masson (2005), os álcoois superiores são recolhidos no destilado juntamente com ésteres e são os principais responsáveis pelo aroma característico da aguardente. Numa aguardente de boa qualidade, os álcoois superiores e ésteres devem estar presentes numa proporção bem equilibrada, geralmente 1:1 (MASSON, 2005; SOUZA; LLISTÓ, 1978). Os álcoois superiores em teor elevado desvalorizam a aguardente, diminuindo o seu valor comercial (SOUZA; LLISTÓ, 1978).

No presente trabalho, a proporção de álcoois superiores e ésters obtida, após 180 dias de armazenamento, foi de 6,5:1 valor este bastante superior ao recomendado para uma aguardente de qualidade. No entanto, a tendência é que, com o passar do tempo de armazenamento, o teor de ésteres se eleve, atingindo uma proporção em relação aos álcoois superiores mais próxima do considerado ideal para uma aguardente de qualidade.

$\mathrm{O}$ aroma típico, agradável, pungente e suave que a aguardente adquire com o envelhecimento, se deve principalmente à formação de ésteres relativamente aromáticos, os quais contribuem para a formação do buquê (CARDOSO, 2006). Com o envelhecimento os destilados adquirem um teor mais elevado de ésteres e, consequentemente, aroma mais agradável (LIMA, 1999). Além das reações de esterificação que ocorre entre os alcoóis e os ácidos da bebida, os ésteres são os principais compostos extraídos da madeira, pelos destilados (MIRANDA et al., 2008; PARAZZI et al., 2008). O acetato de etila é o componente predominante deste grupo (FARIA et al., 2003) sendo responsável pelo odor agradável das bebidas envelhecidas (LITCHEV, 1989).

Os ésteres são formados por um sistema dinâmico, influenciado por mudanças nas concentrações de ácido acético, etanol e água (TÉO et al., 2005). Assim, a perda de água por evaporação e o aumento da concentração de ácido acético durante o envelhecimento resultam em aumento da concentração de acetato de etila (BOZA; OETTERER; 1999).

No presente trabalho, apesar da aguardente de mel ter apresentado um aumento no teor de acidez, durante o período de descanso, o teor de ésteres não apresentou grandes 
alterações, variando de 25,73 para $27,66 \mathrm{mg} / 100 \mathrm{~mL}$ de AA no tempo inicial e ao final dos 180 dias, respectivamente. Destaca-se que o valor máximo estabelecido pela Legislação Brasileira é de $200 \mathrm{mg} / 100 \mathrm{~mL}$ de AA para aguardente de cana (BRASIL, 2005a) e 250 $\mathrm{mg} / 100 \mathrm{~mL}$ de AA para aguardente de frutas (BRASIL, 2008). Téo et al. (2005) também não observaram grandes variações nos teores de ésteres nas aguardentes de cana armazenadas em tonel de amburama, apesar do aumento observado na acidez destes destilados. Estes autores reportaram que as maiores concentrações destes compostos foram observadas nas bebidas armazenadas em tonéis de bálsamo e carvalho, provavelmente devido às características intrínsecas da madeira, um vez que os ésteres são um dos principais compostos que migram da madeira para o destilado (MIRANDA et al., 2008).

Em trabalho realizado por Catão et al. (2010), um aumento no teor de éster foi observado na aguardente cana armazenadas por 6 meses em tonel de Jequetibá (aumentou de 122 para $168 \mathrm{mg} / 100 \mathrm{~mL}$ de AA) e tonel de carvalho (aumentou de 122 para 139 $\mathrm{mg} / 100 \mathrm{~mL}$ de AA), valores estes bastantes superiores aos obtidos no presente trabalho. Por outro lado, Miranda et al. (2008) verificaram concentrações de éster superior $(19,02$ $\mathrm{mg} / 100 \mathrm{~mL}$ de $\mathrm{AA})$ à concentração inicial $(7,50 \mathrm{mg} / 100 \mathrm{~mL}$ de $\mathrm{AA})$ quando a aguardente de cana foi armazenda em tonel de carvalho por 390 dias.

Os componentes secundários são formados principalmente durante a fermentação e separados na etapa de destilação, bem como durante a maturação do destilado (MIRANDA et al., 2008), e conferem qualidade à bebida (TÉO et al., 2005). Desta forma, as pequenas variações no tocante aos componentes secundários observadas no presente trabalho se deve às variações ocorridas nos componentes acidez volátil, aldeídos, ésteres, álcoois superiores, e furfural. Os valores obtidos permaneceram dentro dos limites estabelecidos pela Legislação Brasileira (BRASIL, 2005a; BRASIL, 2008), porém ainda baixos para conferir qualidade a uma aguardente, devido ao curto tempo de armazenamento em tonel de carvalho. Desta forma, a tendência é que ocorra, com o aumento do tempo de armazenamento, uma série de reações gerando compostos que irão agregar características agradáveis à bebida. Neste contexto, vale destacar que segundo Carbello e Faria (1997) a caracterização físico-química e sensorial da aguardente de cana, envelhecida em tonéis de carvalho, gera informações importantes para se adequar o tempo e as condições para a obtenção de produto de qualidade

De acordo com estes autores a aguardente é uma bebida muito apreciada por apresentar aroma e sabor característicos, os quais podem ser modificados pela sua 
estocagem em recipientes de madeira, que além de favorecerem as reações de oxidação ainda transferem para a bebida compostos existentes em sua estrutura, contribuindo assim para melhorar a qualidade sensorial do produto. Tais modificações dependem principalmente do tempo de envelhecimento e do tipo de madeira empregada na fabricação dos tonéis. As características sensoriais da bebida recém-destilada, e o tipo do tonel utilizado para o seu envelhecimento, podem variar muito e afetar de maneira diferente as características sensoriais da bebida resultante.

\subsection{Avaliação Sensorial da Aguardente de Mel}

Segundo Cardoso (2006), a caracterização das propriedades sensoriais e a determinação da importância dessas propriedades na aceitação do produto pelo consumidor, representam a melhor contribuição da análise sensorial.

Bebidas recém-destiladas geralmente apresentam características sensoriais indesejáveis, as quais são modificadas durante o envelhecimento, tornando o produto mais aceitável (CLYNE et al., 1993). O processo de envelhecimento do destilado envolve uma série complexa de reações incluindo aquelas que ocorrem naturalmente no produto, bem como aquelas resultantes da interação do produto com a madeira do tonel (CARDELLO; FARIA, 1997).

No tocante a caracterização sensorial de uma bebida, os testes afetivos têm como objetivo conhecer a opinião de um determinado grupo de consumidores em relação a um ou mais produtos (ROTA, 2008). Neste sentido, um dos testes afetivos utilizados consiste em se verificar a aceitação da bebida, que avalia o quanto os consumidores gostam ou desgostam de um ou mais produtos (MEILGAARD; CIVILLE; CARR, 1988). Segundo Marcellini (2005) a análise de aceitação é uma ferramenta que ajuda a revelar a qualidade do produto.

Desta forma, amostras de aguardente de mel obtidas em diferentes tempos de armazenamento em tonel de carvalho, foram avaliadas sensorialmente por um grupo representativo de consumidores de bebidas alcoólicas (público alvo) utilizando para o teste efetivo uma escala hedônica não estruturada de 9 pontos, sendo os dados obtidos avaliados por meio do Mapa de Preferência Interno (MDPREF) (Figura 3) e a análise de variância 
univariada (ANOVA) com comparação de médias pelo teste de Tukey (Tabela 13), além da Análise Hierárquica de Cluster (Figura 4).

Tabela 13 - Valores médios dos atributos de qualidade da aguardente de mel armazenada em diferentes tempos em tonel de carvalho.

\begin{tabular}{c|c|c|c|c|c}
\hline \multirow{2}{*}{$\begin{array}{c}\text { Dias de } \\
\text { Armazenamento }\end{array}$} & \multicolumn{5}{|c}{ Atributos } \\
\cline { 2 - 6 } & Aparência & Aroma & Sabor & Corpo & $\begin{array}{c}\text { Impressão } \\
\text { global }\end{array}$ \\
\hline 0 & $6,1855^{\mathrm{a}}$ & $5,5727^{\mathrm{b}}$ & $4,9769^{\mathrm{b}}$ & $5,5943^{\mathrm{a}}$ & $5,6639^{\mathrm{a}}$ \\
\hline 30 & $6,5328^{\mathrm{a}}$ & $6,0919^{\mathrm{ab}}$ & $5,3373^{\mathrm{ab}}$ & $6,0222^{\mathrm{a}}$ & $5,8175^{\mathrm{a}}$ \\
\hline 60 & $6,5610^{\mathrm{a}}$ & $6,3743^{\mathrm{a}}$ & $5,5503^{\mathrm{ab}}$ & $5,9105^{\mathrm{a}}$ & $6,0331^{\mathrm{a}}$ \\
\hline 90 & $6,3440^{\mathrm{a}}$ & $5,7008^{\mathrm{ab}}$ & $5,2493^{\mathrm{ab}}$ & $5,5264^{\mathrm{a}}$ & $5,4518^{\mathrm{a}}$ \\
\hline 120 & $6,4928^{\mathrm{a}}$ & $5,9547^{\mathrm{ab}}$ & $5,5946^{\mathrm{ab}}$ & $5,9756^{\mathrm{a}}$ & $5,8568^{\mathrm{a}}$ \\
\hline 150 & $6,3916^{\mathrm{a}}$ & $5,8197^{\mathrm{ab}}$ & $5,2077^{\mathrm{ab}}$ & $5,6699^{\mathrm{a}}$ & $5,5102^{\mathrm{a}}$ \\
\hline 180 & $6,5614^{\mathrm{a}}$ & $6,1395^{\mathrm{ab}}$ & $5,8423^{\mathrm{a}}$ & $6,0524^{\mathrm{a}}$ & $5,9553^{\mathrm{a}}$ \\
\hline
\end{tabular}

*médias com letras iguais na mesma coluna, não diferem entre si estatisticamente $(p \leq 0,05)$

Verifica-se que em relação aos atributos aparência, corpo e impressão global o tempo de armazenamento não influenciou significativamente $(\mathrm{p} \leq 0,05)$ na qualidade da aguardente de mel avaliada. No entanto, em realação ao atributo aroma, o tempo de armazenamento, a partir de 60 dias, conferiu qualidade significativamente $(p \leq 0,05)$ superior a aguardente de mel em relação ao produto recém destilado. No que se refere ao atributo sabor verifica-se que o tempo de armazenamento, a partir de 30 dias, não interferiu estatisticamente na qualidade da bebida com exceção $(\mathrm{p} \leq 0,05)$ para o tempo de 180 dias de armazenamento quando comparado com o destilado recém destilado.

Os atributos aroma e sabor, são os que mais variam em função do tempo de armazenamento, devido às mudanças fisico-químicas que ocorrem na aguardente durante este período (Tabela 12).

$\mathrm{O}$ envelhecimento em tonel de madeira, confere qualidade sensorial à bebida, tornando-a mais suave, com sabor e aroma mais agradável e com coloração amarelada, dependendo do tipo de madeira, tornando-a mais atraente (MIRANDA; HORII; ALCARDE, 2006).

As condições de armazenamento e o tipo de madeira dos barris são responsáveis pelas alterações das características sensoriais dos destilados, quando armazenados por períodos de 2 a 10 anos (MAIA et al., 1994). Deste modo, o tempo de armazenamento em barril de carvalho deve ser suficiente para que ocorram reações fisico-químicas que contribuem para a qualidade sensorial da aguardente. Desta forma, os resultados apresentados na Tabela 12 revelam que o tempo de armazenamento de 180 dias em tonel 
de carvalho não foi suficiente para a ocorrência de reações desejadas, o que influenciaria nas características sensoriais da bebida, tornado-a mais agradável e suave.

No entanto, apesar do pouco tempo de descanso, a aguardente de mel apresentou uma boa aceitação pelos provadores. De um modo geral, a média das notas das amostras situaram-se na escala hedônica próximas à nota 6 (região da categoria "gostei ligeiramente") e 5 (região da categoria "não gostei, nem desgostei"), o que sugere que novas avaliações devam ser realizadas semestralmente por pelo menos 24 meses de envelhecimento.

Cardello e Faria (1998) verificaram que a aceitação de amostras de aguardente de cana envelhecidas em tonel de carvalho por 0, 12, 24, 36 e 48 meses, aumentou significativamente $(\mathrm{p} \leq 0,05)$ com o tempo de envelhecimento. Em outro trabalho, os mesmos autores (CARDELLO; FARIA, 2000) obsevaram que amostras com 24, 36 e 48 meses de envelhecimento apresentaram as maiores médias para a aceitação em relação aos atributos aroma, sabor, impressão global e cor, evidenciando que o envelhecimento melhora significativamente a aceitação da bebida.

Vale salientar que $39 \%$ dos provadores manifestaram que pelo menos uma das amostras avaliadas apresentavam um teor alcoólico acentuado, mesmo tendo sido observado (Tabela 12) que a concentração de álcool (44 $\left.{ }^{\circ} \mathrm{GL}\right)$ na aguardente de mel se encontrava dentro dos limites estabelecidos pela legislação brasileira (55 $\left.{ }^{\circ} \mathrm{GL}\right)$. Esta percepção pode ser atribuída ao pouco tempo de descanso da aguardente, o que não foi suficiente para gerar outros compostos que conferem qualidade sensorial à bebida, e que provavelmente, reduziria a sensação de excesso de álcool. Segundo Cardello e Faria (1999), o envelhecimento da aguardente em tonéis de madeira promove diminuição significativa do sabor alcoólico e da agressividade da bebida, com simultâneo aumento da doçura e do sabor de madeira, proporcionando uma efetiva melhora nas características sensoriais do produto.

Os resultados de aceitação em relação à impressão global foram também analisados estatisticamente por meio da análise multivariada o que permitiu traçar o Mapa de Preferência Interno - MDPREF. Esta ferramenta tem por finalidade analisar dados afetivos, levando-se em consideração a resposta individual de cada consumidor e não 
somente a média do grupo de consumidores que avaliaram o produto (MaCFIE; THONSON, 1994), conforme ilustrado na Figura 3.

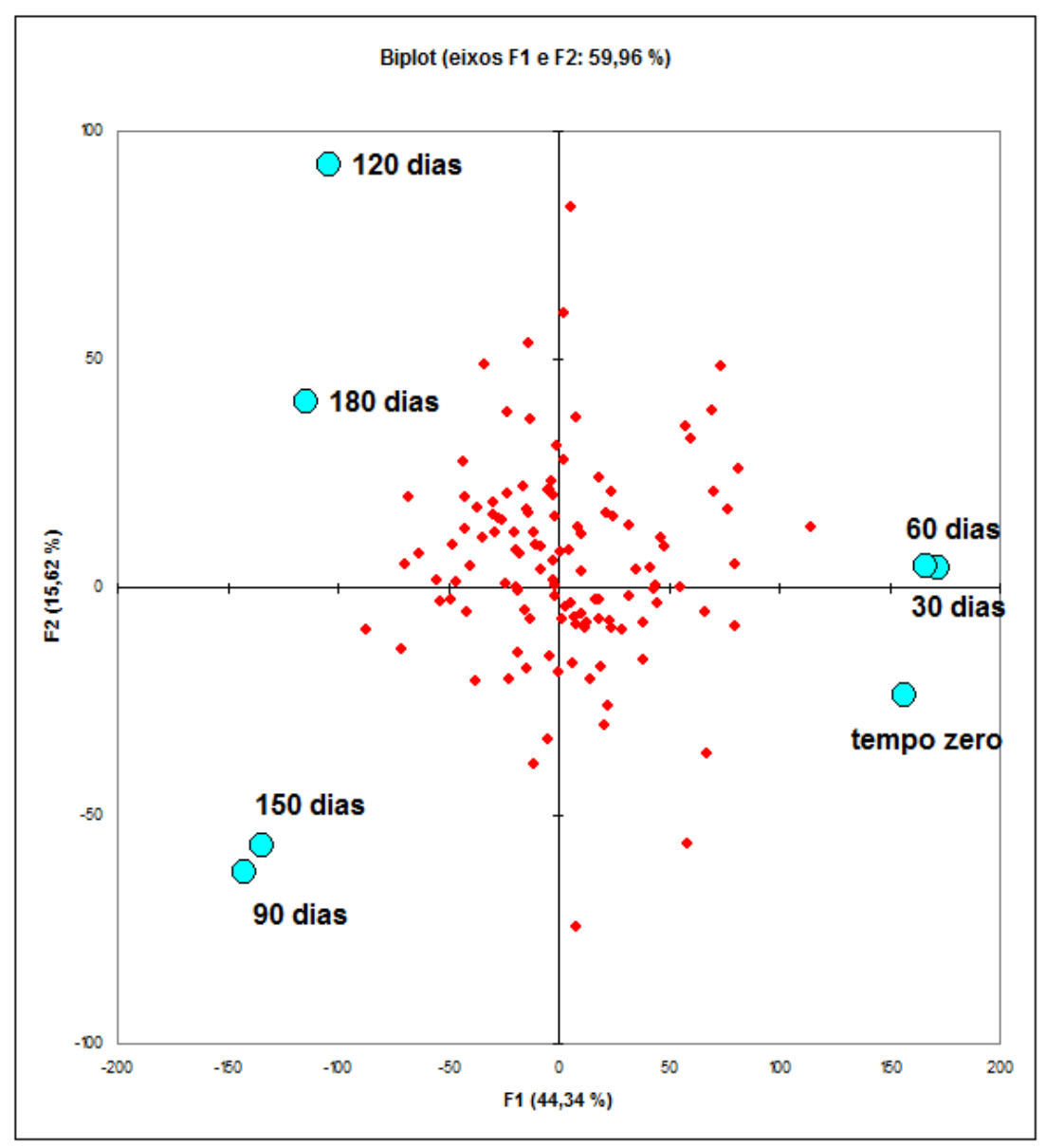

Figura 3 - Mapa de Preferência Interno referente ao atributo “impressão global” da aguardente armazenada em tonel de carvalho em diferentes tempos.

Por meio desta técnica é possível explicar 59,96\% da variabilidade dos resultados relativos a aceitação das amostras de aguardente de mel armazenada em tonel de carvalho em diferentes tempos. Desta forma, verifica-se que neste tipo de gráfico os provadores ficam distribuídos próximos à região das amostras de sua preferência. Assim, é possível observar que a amostra referente a 180 dias de armazenamento foi preferida por um maior número de consumidores (pontos vermelhos), enquanto que as amostras armazenadas por 90, 120 e 150 dias foram as menos preferidas. Nota-se ainda que as amostras referentes aos tempos zero, 30 e 60 dias de armazenamento apresentaram um nível de aceitação intermediário. 
Cardello e Faria (2000), verificaram por meio da análise do Mapa de Preferência Interno que os consumidores preferiram aguardente de cana envelhecidas por 24, 36 e 48 meses, sendo as aguardentes sem envelhecimento as de menor aceitação

Uma outra forma de se avaliar os resultados consiste em se agrupar as amostras de acordo com suas similaridades, utilizando todas as variáveis disponíveis e representá-los de maneira bidimensional por meio de um dendrograma (MOITA NETO; MOITA, 1998). Desta forma, o dendograma relativo as amostras de aguardente de mel obtidas no presente trabalho encontra-se apresentado na Figura 4.

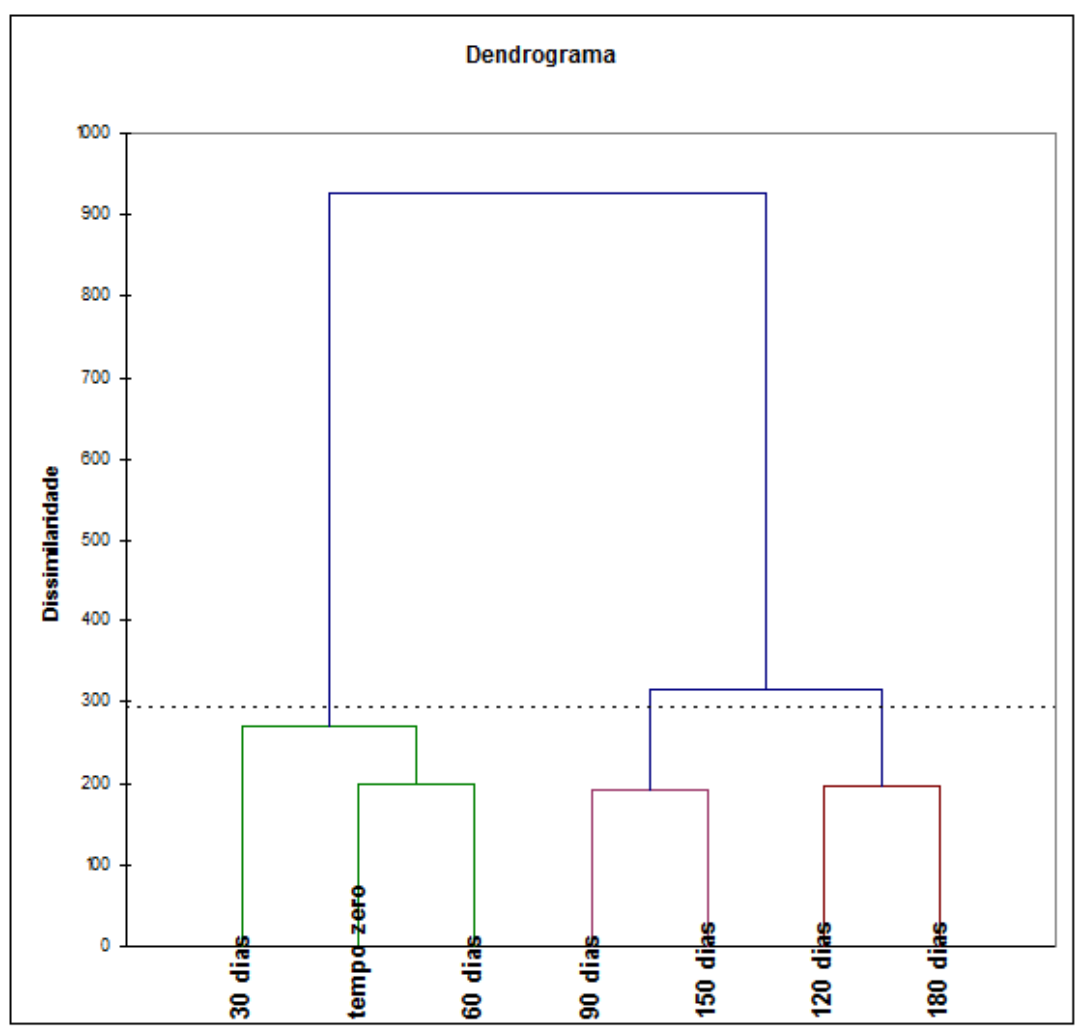

Figura 4 - Dendrograma de similaridade entre as aguardente armazenadas em tonel de carvalho.

Por meio da Análise Hierarquica de Cluster (Figura 4), é possível verificar que, os agrupamentos localizados abaixo da linha pontilhada (limite) indicam que existem três grupos de consumidores com preferências similares, que consiste de um grupo que preferiu as amostras do tempo inicial, 30 e 60 dias; um segundo com preferência para as amostras de 90 e 150 dias e um terceiro que preferiu as amostras com 120 e 180 dias de armazenamento em tonel de carvalho. 
Nota-se que existe uma correlação entre estes resultados e aqueles representados no mapa de preferência interno, no qual é possível verificar os três grupos com preferências similares localizados em regiões semelhantes do mapa (Figura 3).

A atitude de compra por parte dos provadores também foi avaliada no presente trabalho, cujos valores obtidos estão representados na Figura 5, onde é possível observar que a amostra que apresentou melhor atitude em relação à compra $(79,17 \%)$ foi a aguardente corresponde a 60 dias de armazenamento, sendo que 9,17\% afirmaram que "certamente compraria" 38,33\% "provavelmente compraria" e 31,67\% "tenho dúvida se compraria ou não". Nota-se que na seqüência a aguardente armazenada por 180 dias apresentou uma atitude de compra positiva por parte de $75,83 \%$ dos provadores, sendo que $5,83 \%$ "certamente compraria", 48,33\% "provavelmente compraria" e 21,67\% responderam "tenho dúvida se compraria ou não". Observa-se ainda que as aguardentes referentes aos tempos 0 e 30 dias de armazenamento apresentaram maior freqüência para “certamente não compraria”, correspondendo a 11,67 e 10,00 \%, respectivamente.

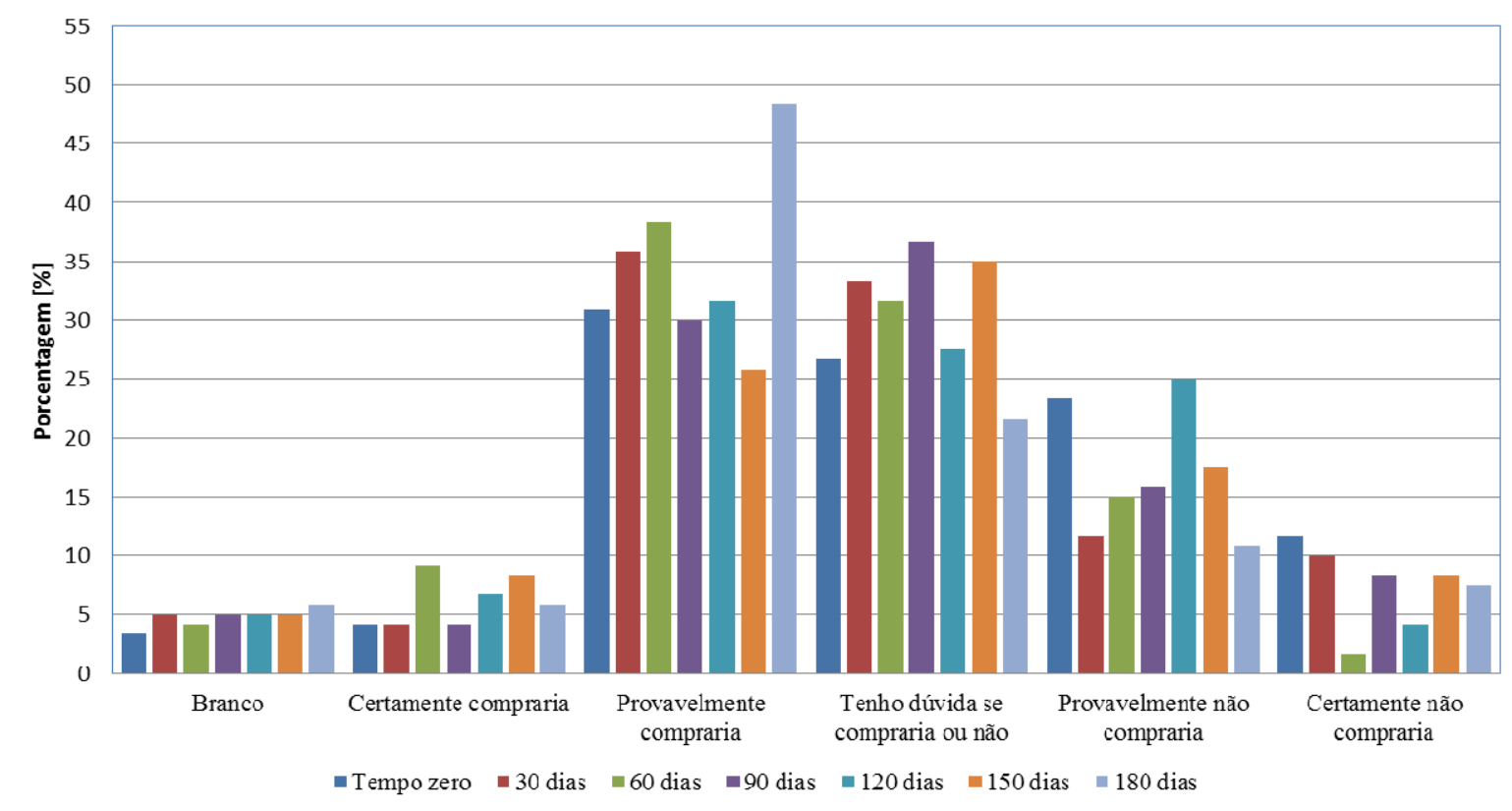

Figura 5 - Representação gráfica do teste de aceitação em relação à atitude de compra.

Uma das formas de se incorporar qualidade ao destilado consiste em se aumentar o tempo de armazenamento, quando ocorrerá evaporação de alguns compostos voláteis, reações de adsorção ou interação de certas substâncias da bebida com a madeira. Esta interação resulta na incorporação à bebida de algumas substâncias da própria madeira ou na reação de substâncias da própria bebida com alguns produtos característicos de cada 
madeira dando o sabor agradável ao destilado (CARDOSO 2006). O armazenamento prolongado em recipientes de madeira leva ao envelhecimento e, dentro de limites razoáveis, quanto mais longo, melhores qualidades aromáticas e degustativas transmitem ao destilado (LIMA, 1999).

Deste modo, o aumento do tempo de armazenamento irá agregar qualidades sensoriais a aguardente de mel conferindo à mesma melhor aceitação por parte dos consumidores. Neste contexto, vale salientar que a aguardente de mel deveria primeiramente descansar de 4 a 6 meses em tonel de inox e posteriormente submetida ao envelhecimento em tonel de carvalho. Este procedimento não foi adotado devido a falta de tempo hábil para tanto, tendo em vista o cumprimento das obrigações dentro do prazo regimental do PPG-BI. 


\section{CONCLUSÕES}

Os resultados obtidos no presente estudo permitem concluir que:

- Das 10 leveduras isoladas a partir de frutas e de mel, 5 apresentaram características promissoras para serem avaliadas como agentes de fermentação alcoólica, o que sugere a realização de novos estudos;

- O mosto formulado a partir de mel deve ser suplementado com nutrientes e que o extrato de levedura comercial mostrou ser o suplemento mais adequado para a eleboração de aguardente.

- A levedura selecionada para produção de aguardente de mel em escala piloto (levedura $\mathrm{T}$ ), isolada de borra de mel e posteriormente identificada como Saccharomyces cereviseae e nomeada Saccharomyces cerevisiae EEL 2009, além de apresentar desempenho fermentativo satisfatório apresenta a capacidade de flocular, o que contribui para o desenvolvimento do processo de fermentação por meio do sistema de batelada repetida, reduzindo o tempo de decantação.

- A aguardente de mel produzida em escala piloto apresentou características físicoquímicas em conformidade com os padrões exigidos pela legislação para aguardente de frutas.

- O tempo de armazenamento de 180 dias em tonel de carvalho de $200 \mathrm{~L}$ não foi suficiente para a ocorrência de reações desejadas, o que influenciaria nas características sensoriais da bebida, tornado-a mais agradável e suave;

- A análise sensorial mostrou que, apesar do pouco tempo de descanso, a aguardente de mel apresentou uma boa aceitação por parte dos provadores e, a amostra referente a 180 dias de armazenamento foi a preferida apresentando melhor resultado para a atitude de compra, juntamente com a amostra armazenada por 60 dias;

- O aumento do tempo de armazenamento irá agregar qualidades sensoriais a aguardente de mel conferindo à mesma melhor aceitação por parte dos consumidores;

- O mel se apresenta como uma alternativa viável para a formulação de mosto para produção de aguardente no período de entre safra, contribuindo para melhor aproveitamento das instalações e como fonte alternativa de renda para o produtor rural. 


\section{SUGESTÕES PARA TRABALHOS FUTUROS}

Os resultados obtidos no presente trabalho permitem sugerir:

- A realização de novos experimentos avaliando as outras cepas de leveduras isoladas (D, H e P) e que apresentaram desempenho fermentativo satisfatório;

- A realização de novas avaliações ao longo do tempo de envelhecimento incluindo caracterização fisico-química e sensorial, com vistas a verificar a evolução da formação de compostos que conferem qualidade a aguardente de mel. 



\section{REFERÊNCIAS}

ADAMS, J. Análise da indústria do mel. Inserção de micro e pequenas empresas no cenário internacional, 2006, v. 2, 66p.

ALCARDE, A. R.; SOUZA, P. A.; BELLUCO, A. E. S. Aspectos da composição química e aceitação sensorial da aguardente de cana-de-açúcar envelhecida em tonéis de diferentes madeiras. Ciênc. Tecnol. Aliment., v. 30, n. 1, p. 226-232, 2010.

ALLEN, K. L., MOLAN, P. C., REID, G. M. A survey of the antibacterial activity of some New Zealand honeys. Journal of Pharmacy and Pharmacology, v.43, p. 817-822, 1991.

ALMEIDA, M. A. D.; CARVALHO, C. M. S. Apicultura: uma oportunidade de negócio sustentável, Salvador: Sebrae Bahia, 2009, 52 p.

ALVARENGA, L. M., MAIA, A. B. R., OLIVEIRA, E. S. Processamento, avaliação química e sensorial de aguardente de manga (Mangifera indica L.). In: CONGRESSO BRASILEIRO DE CIÊNCIA E TECNOLOGIA DE ALIMENTOS, 20, 2006, Curitiba. Anais... Curitiba: SBCTA, 2006. 1 CD-ROM.

ALVES, G. L.; CARDELlO, H. M. A. B., FARIA, J. B. Estudos Preliminares Sobre a Origem dos Compostos Sulfurados Presentes na Cachaça. Alim. Nutri., v. 13, p. 83-92, 2002.

ANJOS, J. P.; CARDOSO, M. G.; SANTIAGO, W. D.; MACHADO, A. M. R.; ZACARONI, L. M.; MENDONÇA, J. G. P. Caracterização fisico-química da cachaça durante o período de envelhecimento em tonel de carvalho (Quercus sp.). In: CONGRESSO BRASILEIRO DE QUÍMICA, 50, 2010, Cuiabá. Anais eletrônicos...Cuiabá: CBQ, 2010. Disponível em:

http://www.abq.org.br/cbq/2010/trabalhos/9/9-279-8225.htm. Acesso em: 22 jun. 2011

APOSTOLOPOUlOU, A.A.; FLOUROS, A. I.; DEMERTZIS, P. G.; AKRIDADEMERTZI, K. Differences in concentration of principal volatile constituents in traditional Greek distillates. Food Control, v. 16, p. 157-164, 2005.

AQUINO, F. W. B.; AMORIN, A. G. N.; PRATA, L. F.; NASCIMENTO, R. F. Determinação de aditivos, aldeídos furânicos, açúcares e cafeína em bebidas por cromatografia líquida de alta eficiência: validação de metodologias. Ciênc. Tecnol. Aliment., v. 24, n. 1, p. 32-38, 2004. 
ARAÚJO, D. R.; SILVA, R. H. D.; SOUSA, J. S. Avaliação da qualidade físico-química do mel comercializado na cidade de Crato, CE. Revista de Biologia e Ciências da Terra, v. 6, n. 1, p. 1-5, 2006.

ARIAS, C.R., BURNS, J.K., FRIEDRICH, L.M., GOODRICH, R.M., PARISH, M.E. Yeast species associated with orange juice: evaluation of different identification methods. Applied and Environmental Microbiology, v. 68, n. 4, p. 1955-1961, 2002.

AROUCHA, E. M. M.; OLIVEIRA, A. J. F; NUNES, G. H. S.; MARACAJÁ, P. B.; SANTOS, M. C. A. Qualidade do mel de abelha produzido pelos incubados da IAGRAM e comercializado no município de Mossoró/RN. Caatinga, v. 21, n. 1, p. 211-217, 2008.

ARRUdA, C. M. F., MARChini, L. C., SODRÉ, G. S., MORETI, A. C. C. Características físico-químicas de amostras de méis de apis mellifera L., 1758 (hymenoptera, apidae) da região da chapada do Araripe, município de Santana do Cariri, estado do Ceará. Indústr.anim., N. Odessa,v.61, n.2, p.141-150, 2004.

ARRUDA, E. R. A. Aproveitamento da batata (Solanun tuberosum)para a produção de álcool. Santa Maria, 2006. 48 p. Dissertação (Mestrado em Ciência e Tecnologia de Alimentos) - Universidade Federal de Santa Maria.

ASQUIERI, E. R., SILVA, A. G. M., CÂNDIDO, M. A. Aguardente de jabuticaba obtida da casca e borra da fabricação de fermentado de jabuticaba. Ciência e Tecnologia de Alimentos, v. 29, n. 4, p. 896-904, 2009.

ASSIL, H. I., STERLING, R., SPORNS, P. Crystal control in processed liquid honey. Journal of Food Science, v. 56, n. 4, p. 1034-1037, 1991.

AZEVEDO, S. M.; CARDOSO, M. G.; PEREIRA, N. E.; RIBEIRO, C. F. S.; SILVA, V. F.; AGUIAR, F. C. Ciênc. agrotec., Lavra, v. 27, n. 3, p. 618-624, 2003.

BADOTTI, F.; DÁRIO, M. G.; ROSA, C. A.; STAMBUK, B. U. Caracterização bioquímica e molecular de linhagens de Saccharomyces cerevisiae isoladas de fermentações artesanais de caldo de cana e melado para a produção de cachaça em Florianópolis-SC. Braz. J. Food Technol., v. 13, n. 3, p. 205-213, 2010.

BARHATE, R.S.; SUBRAMANIAN, R; NANDINI, K.E.; HEBBER, H.U. Processing of honey using polymeric microfiltration and ultrafiltration membranes. J. Food Eng., v.60, n.1, p.1-6, 2003. 
BELL, A. A.; OUGH, C. S.; KLIEWER, W. M. Effects on must and wine composition, rates fermentation, and wine quality of nitrogen fertilization of Vitis vinifera var. Thompson seedless grapevine. American Journal of Enology and Viticulture, v. 30, n. 2, p. 124-129, 1979.

BENDINI, J. N.; SOUZA, D. C. Caracterização físico-química do mel de abelhas proveniente da florada do cajueiro. Ciência Rural, v. 38, n. 2, p. 565-567, 2008.

BERRY, D.R.; SALAUGHTER, J. C. Alcoholic beverage fermentations. In: LEA, A. G. H.; PIGGOTT, J. R. Fermented Beverage Production. $2^{\text {nd }}$ ed. New York: Kluwer Academjc/Plenum Publishers, 2003. Cap. 2, p. 25-39.

BIZELLI, L. C.; RIBEIRO, C. A. F.; NOVAES, F. V. Dupla Destilação da Aguardente de Cana: Teores de Acidez Total e de Cobre. Scientia Agricola, v.57, n.4, p.623-627, 2000.

BOGDANOV, S. Antibacterial substances in honey. Switzerland: Swiss Bee Research Centre, 1997.

BOGDANOV, S.; LULLMANN, C.; MARTIN, P.; OHE, W.; RUSSMANN, H.; VORWOHL, G.; ODDO, L. P.; SABATINI, A.; MARCAZZAN, G. L.; PIRO, R.; FLAMINI, C.; MORLOT, M.; LHERETIER, J.; BORNECK, R.; MARIOLDAS, P.; TSIGOURI, A.; KERKVLIET, J.; ORTIZ, A.; IVANOV, T; D`ARCY, B.; MOSSEL, B.; VIT, P. Honey quality, methods of analysis and international regulatory standards: review of the work of the international honey commission. Local: Swiss Bee Research Centre, 2000.

BOGDANOV, S. Harmonised methods of the international honey commission. Local: International Honey Commission, 2002.

BOGDANOV, S; RUOFF, K.; ODDO, L. P. Physico-chemical methods for the characterization of unifloral honeys: a review. Apidologie, v. 35, p. 4-17, 2004.

BOGUSZ JUNIOR, S.; KETZER, D.C.M.; GUBERT, R.; ANDRADES, L.; GOBO, A. B. Composição química da cachaça produzida na região noroeste do Rio Grande do Sul, Brasil. Ciência e Tecnologia de Alimentos, v. 26, n. 4, p. 793-798, 2006.

BORTOLINI, F.; SANT'ANNA, E. S.; TORRES, R. C. Comportamento das fermentações alcoólica e acética de sucos de kiwi (Actinidia deliciosa); composição dos mostos e métodos de fermentação acética. Ciência e Tecnologia de Alimentos, v. 21, n.2, p. 236243, 2001. 
BOSCOLO, M.; BEZERRA, C. W. B.; CARDOSO, D. R.; LIMA-NETO, B. S.; FRANCO, D. W. Identification and dosage by HRGC of minor alcohols and esters in Brazilian sugar-cane spirit. J. Braz. Chem. Soc. v. 11, p. 86-90, 2000.

BOZA, Y.; HORII, J. Influência da Destilação Sobre a Composição e a Qualidade Sensorial da Aguardente de Cana-de-Açúcar. Ciência e Tecnologia de Alimentos. v. 18, n. 4, 1998.

BOZA, Y.; OETTERER, M. Envelhecimento de aguardente de cana. Boletim da Sociedade Brasileira de Ciência e Tecnologia de Alimentos, Campinas, v.1, n.33, p.8-15, 1999.

BRAGA, V. S. A influência da temperatura na condução de dois processos fermentativos para produção de cachaça. Piracicaba, 2006, 90P.. 90p. Dissertação (Mestrado em Ciências) - Escola Superior de Agricultura "Luiz de Queiróz”, Universidade de São Paulo.

BRASIL. Ministério da Agricultura, Pecuária e Abastecimento. Instrução Normativa 11, de 20 de outubro de 2000: Aprova o Regulamento Técnico de Identidade e Qualidade do Mel. Revoga a Portaria $n^{\circ} 367$ de 04/09/1997. Diário Oficial. Brasília, DF. 23 de outubro de 2000. Seção 1, p. 23.

BRASIL. Ministério da Agricultura, Pecuária e Abastecimento. Instrução Normativa $\mathrm{n}^{\mathrm{o}}$ 13,de 29 junho de 2005: Aprova o Regulamento Técnico para Fixação dos Padrões de Identidade e Qualidade para Aguardente de Cana e para Cachaça. Diário Oficial. Brasília, DF. 30 de junho de 2005a. Seção 1, p. 3.

BRASIL. Ministério da Agricultura, Pecuária e Abastecimento. Instrução Normativa ${ }^{\circ}$ 24, de 08 de setembro de 2005: Aprova o Manual Operacional de Bebidas e Vinagres. Revoga a Portaria $n^{0} 76$ de 27/11/1986. Diário Oficial. Brasília, DF. 20 de setembro de 2005b. Seção 1, p. 11.

BRASIL. Ministério da Agricultura, Pecuária e Abastecimento. Portaria ${ }^{\circ}$ 65, de 23 de abril de 2008: regulamento técnico para a fixação dos padrões de identidade e qualidade para aguardente de fruta. Diário Oficial. Brasília, DF. 24 de abril de 2008. Seção 1, p. 11.

BRASIL. Ministério da Agricultura, Pecuária e Abastecimento. Decreto $n^{\circ}$ 6871, de 04 de junho de 2009: Regulamenta a Lei ${ }^{\circ}$ 8.918, de 14 de julho de 1994, que dispõe sobre a padronização, a classificação, o registro, a inspeção, a produção e a fiscalização de bebidas. Diário Oficial. Brasília, DF. 04 de junho de 2009. Seção 1, p. 20. 
BRASIL, I. M.; MAIA, G. A.; FIGUEIREDO, R. W. Produção de suco clarificado de goiaba com uso de enzima pectinolítica e agentes "fining". Pesquisa agropecuária brasileira, v. 30, n. 6, p. 855-866, 1995.

BROWNING, Z.; WALKER III, C.; HANSEN, G. Reference guide to nature's sweetener. National Honey Board. Disponível em: $<$ http://www.honey.com/images/downloads/beer.pdf\#search=\%27beer\%27>. Acesso em: 17 ago. 2010.

CAMARGO, R.C.R.; LOPES, M.T.R.; PEREIRA, F.M.; VILELA, S.L.O. Produção de Mel. Net. Piauí: julho de 2003. Disponível em: $<$ http://sistemasdeproducao.cnptia.embrapa.br/FontesHTML/Mel/SPMel/mel.htm>.

Acesso em 14/07/2010.

CAMPOS, G.; DELlA-MODESTA, T. J. P. S.; BAPTISTA, K. E.; GOMIDES, M. F.; GODOY, R. L. Classificação do mel em floral ou mel de melato. Ciência e Tecnologia de Alimentos, n. 23, v.1, p. 1-5, 2003.

CAMPOS, L. M. A. S.; LEIMANN, F. V.; PEDROSA, R. C.; FERREIRA, S. R. S. Free radical scavenging of grape pomace extracts from Cabernet sauvingnon (Vitis vinifera). Bioresource Technology, v. 99, n. 17, p. 8413-8420, 2008.

CARDELlO, H. M. A. B., FARIA, J.B. Modificações físico-químicas e sensoriais de aguardente de cana envelhecida em tonéis de carvalho. Bol. Centro de Pesquisa e Processamento de Alimentos, v.15, n.2, p. 87-100, 1997.

CARDELLO, H. M. A. B.; FARIA, J. B. Análise descritiva quantitativa da aguardente de cana durante o envelhecimento em tonel de carvalho (Quercus Alba L.). Ciência e Tecnologia de Alimentos, v. 18, n. 2, Maio/Julho, 1998.

CARDEllo, H. M. A. B.; FARIA, J. B. Análise tempo-intensidade de características sensoriais de cachaça de cana durante o envelhecimento em tonel de carvalho (Quercus sp.). Boletim da Sociedade Brasileira de Ciência e Tecnologia de Alimentos, v. 33, n. 1, p. 27-34, 1999.

CARDELLO, H. M. A. B.; FARIA, J. B. Análise da aceitação de aguardentes de cana por testes afetivos e mapa de preferência interno. Ciência e Tecnologia de Alimentos, v. 20, n.1, 2000. 
CARDOSO, D. R.; ANDRADE-SOBRINHO,L. G.; LEITE-NETO, A. F.; RONI V. RECHE, R. V.; ISIQUE, W. D.; FERREIRA, M. M. C.; LIMA-NETO, B. S.; FRANCO, D. W. Comparison between Cachaça and Rum Using Pattern Recognition Methods. Journal of Agricultural and Food Chemistry. v. 52, p. 3429-3433, 2004.

CARDOSO, M. G. Produção de aguardente de cana. 2a ed. Lavras: Editora UFLA, 2006. 445 p.

CATÃO, C. G.; PAES, J. B.; GOMES, J. P.; ARAÚJO, G. T. Qualidade da madeira de cinco espécies florestais para o envelhecimento da cachaça. Revista Brasileira de Engenharia Agrícola e Ambiental, v.15, n.7, p.741-747, 2011.

CBA - Confederação Brasileira de Apicultura, 2007. Brasil Apícola. Disponível em: $<$ http://www.brasilapicola.com.br/brasil-apicola $>$. Acesso em: 16/07/2010.

CLETO, F. V. G.; MUTTON, M. J. R. Rendimento e composição das aguardentes de cana, laranja e uva com utilização de lecitina no processo fermentativo. Ciência e agrotecnologia. v. 28, n. 3, p. 577-584, 2004.

CLYNE, A.; CONNER, J. M.; PATERSON, A.; PIGGOT, J. R. The effect of cask charring on Scotch whisky maturation. International Journal of Food Science and Technology, v. 28, p. 69-81, 1993.

CORTOPASSI-LAURINO, M; GELLI, D.S. Analyse pollinique, propriétes physicochimiques et action antibactérienne des miels d'abeilles africanisées Apis mellifera et de Méliponinés du Brésil. APIDOLOGIE, Paris, v.22, n.1, p.61-73, 1991.

DANTAS, H. J.; VILAR, F. A.; SILVA, F. L. H.; SILVA, A. S. Avaliação da influência da velocidade de destilação na análise físico-química de aguardente de cana-de-açúcar. Revista Brasileira de Produtos Agroindustriais, Campina Grande, v.9, n.2, p.101-109, 2007.

DE MARIA, C. A. B.; MOREIRA, R. F. A. Compostos voláteis em méis florais Quim. Nova, v. 26, n. 1, p. 90-96, 2003.

DIAS, D. R.; PANTOJA, L.; SCHWAN, R. F. Fermentados de frutas. In: VENTURINI FILHO, W. G. Bebidas Alcoólicas - Ciência e Tecnologia. São Paulo: Editora Blucher, 2010. p. 85-111. 
DIÉGUEZ, S. C.; DE LA PEÑA, M. L. G.; GÓMEZ, E. F. Concentration of Volatiles in Marc Distillates from Galicia According to Storage Conditions of the Grape Pomace. Chromatographia Supplement, v. 53, p. 406-411, 2001.

DOMINGUES, L. M. A. R. Estirpes floculantes de Saccharomyces cerevisiae geneticamente modificadas para a utilização da lactose: construção e aplicação biotecnologica. Minho, 2001. Dissertação (Doutorado em Engenharia Química e Biológica) - Escola de Engenharia, Universidade do Minho - Minho - Portugal.

DORNELlES, A. S.; RODRIGUES, S. Fermentação Alcoólica de Caldo de Cana utilizando grãos de Kefir. Ciência Agronômica, v. 37, n. 3, p. 386-390, 2006.

DORNELLES, A. S; RODRIGUES, S.; GARRUTI, D. S. Aceitação e perfil sensorial das cachaças produzidas com Kefir e Saccharomyces cerevisae. Ciência e Tecnologia de Alimentos, v. 29, n. 3, p. 518-522, 2009.

DOWNEY, G., HUSSEY, K., KELly, J. D., WAlShe, T. F., MARTIN, P. G. Preliminary contribution to the characterisation of artisanal honey produced on the island of Ireland by palynological and physico-chemical data. Food Chemistry, v. 91, n. 2, p. 347-354, 2005.

DRAGONE, G.; MUSSATO. S. I.; VILANOVA, M.; OLIVEIRA, J. M.; TEIXEIRA, J. A. Obtenção e caracterização de bebida destilada a partir da fermentação do soro de queijo. Braz. J. Food Technol., junho 2009, VII BMCFB. 03 à 07 de Dezembro. Lorena - SP.

DUTRA, S. V.; DAUDT, C. E.; SOUZA, M. Aminoácidos livres e uréia durante a fermentação de mosto de Chardonnay com diferentes leveduras. Ciência e Tecnologia de Alimentos, v. 19, n. 2, p. 179-182, 1999.

EGOROV, I. A.; RODOPULO, A. K. Investigation of aroma-forming substances in cognac spirits in their aging process. Applied Biochemistry and Microbiology, v. 30, n. 4-5, p. 539-542, 1994.

FALLICO, B., ZAPPALA, M., ARENA, E., VERZERA, A. Effects of conditioning on HMF content in unifloral honeys. Food Chemistry. v. 85, p. 305-313, 2004.

FARIA, J. B.; POURCHET-CAMPOS, M. A. Eliminação do cobre contaminante das aguardentes de cana (Saccharum officinarum L.) brasileiras. Aliment. Nutr., v. 1, p. 11726, 1989. 
FARIA, J. B.; LOYOLA, E.; LÓPEZ, M. G.; DUFOUR, J. P. Cachaça, Pisco and Tequila. In: LEA, A. G. H.; PIGGOTT, J. R. Fermented beverage production. $2^{\text {nd }}$ ed. New York: Klumer Academic/Plenum Publishers, 2003. cap. 15, p. 335-363.

FERNANDES, W. J.; CARDOSO, M. G.; VILELA, F. J.; MORAIS, A. R.; SILVA, V. F.; NELSON, D. L. Physicochemical quality of a blend of domestic cachaças from the south of Minas Gerais. Journal of Food Composition and Analysis, v. 20, p. 257-261, 2007.

FERREIRA, L. G. R.; ALBUQUERQUE, I. M. Alterações nos níveis de prolina nas folhas e partes florais de caupi (vigna unguiculata (1.) walp) induzidas por variações de temperatura. Rev. Bras. Fisiol. Vegetal. v. 2, n. 1, p. 71-76, 1990.

FLORENCIO, L. Popular, premium, envelhecida e também internacional. $\begin{array}{llllll}\text { Engarrafador } & \text { Moderno. } & \text { p. 20-24, abril de }\end{array}$ $<$ http://www.engarrafadormoderno.com.br/edicoes/Edição_179.pdf $>$. Acesso em 23 de junho de 2010.

FRANCO, A. C.; FROTA, M. B.; FARIA, J. B. A redestilação da cachaça e sua influência na qualidade sensorial. Alim. Nutr., v.20, n.2, p. 331-334, abr./jun. 2009.

FURTADO, J. L. B.; BEZERRA, C. W. B.; MARQUES, E. P.; MARQUES, A. L. B. Cianeto em tiquiras: riscos e metodologia analítica. Ciênc. Tecnol. Aliment., v. 27, n. 4, p. 694-700, 2007.

GLEITER, R. A.; HORN, H.; ISENGARD, H. -D. Influence of type and state of crystallization on the water activity of honey. Food Chemistry, v. 96, p. 441-445, 2006.

HASHIZUME, T. Fundamentos de tecnologia do vinho. In: AQUARONE, E.; LIMA, U.A.; BORZANI, W. (Ed.). Alimentos e bebidas produzidos por fermentação. São Paulo: E. Blücher, v. 5, 1983. 243p.

HENRIQUES, A. Mel: um milagre da natureza para o tratamento de feridas? Tipo: revisão. School of Applied Sciences; University of Wales Institute; Wales, Cardiff, UK, 2004. Disponível em: < http://www.Forma-te.com/Mediateca>. Acesso em: 17 ago. 2010.

HENSCHKE, P. A.; OUGH, C. S. Urea accumulation in fermenting grapes juice. American Journal of Enology Viticulture, v. 42, n. 4, p. 317-321, 1991.

HERNÁNDEZ-GÓMEZ, L. F.; ÚBEDA, J.; BRIONES, A. Melon fruit distillates: comparison of different distillation methods. Food Chemistry, v. 82, p. 539-543, 2003. 
HERNÁNDEZ-GÓMEZ， L. F.; ÚBEDA-IRANZO， J.; GARCÍA-ROMERO， E.; BRIONES-PÉREZ, A. Comparative production of different melon distillates: Chemical and sensory analyses. Food Chemistry, v. 90, p. 115-125, 2005.

HSDB. Hazardous Substances Data Bank. Chemical summary for methanol. MEDLARS Online Information Retrieval System, National Library of Medicine. 1994. Disponível em: $<$ http://www.epa.gov/chemfact/s_methan.txt>. Acesso em: 12 mai. 2011.

ILHA, E. C.; BERTOLDI, F. C.; REIS, V. D. A.; SANT'ANNA, E. Rendimento e Eficiência da Fermentação Alcoólica na Produção de Hidromel. Boletim de pesquisa e desenvolvimento, Embrapa, v. 84, 2008.

ISIQUE, W. D.; CARDELlO, H. M. A. B.; FARIA, J. B. Teores de Enxofre e Aceitabilidade de Aguardentes de Cana Brasileiras. Ciência e Tecnolonogia de Alimentos, v. 18, n. 3, 1998.

JANZANTTI, N. S. Compostos Voláteis e qualidade de sabor de cachaça. Campinas, 2004. 123 p. Tese (Doutorado em Ciência de Alimentos) - Faculdade de Engenharia de Alimentos, Universidade Estadual de Campinas.

JERONIMO, E. M.; OLIVEIRA, E. S.; SOUZA, E. L. R.; SILVA, M. A.; SERRA, G. E. Addition of proteic nitrogen during alcoholic fermentation for the production of cachaça. Scienc Agricutural, v.65, n.2, 2008.

JO, C.; KIM, J. K.; KANG, H. J.; LEE, E. Y.; BYUN, M. W. Irradiation Effects on the Decontamination of Microorganisms in Honey. In: INTERNATIONAL SYMPOSIUM "NEW FRONTIER OF IRRADIATED FOOD AND NON-FOOD PRODUCTS", 2005, KMUTT, Bangkok, Thailand. Proceedings: 2005, p.22-23.

JUStinO, M.; MUTTON, R.; MUTTON, M. A. Aguardente. In: FILHO, W. G. V. Tecnologia de bebidas: matéria prima, processamento, BPF/APPCC, legislação e mercado, São Paulo: Editora Edgard Blucher. 2005. p. 485-522.

KESSLER, A. Efeitos in vitro $\mathrm{e}$ in vivo da prolina sobre a atividade da creatininaquinase em encéfalo de ratos jovens. Porto Alegre, 2003. 69 p. Dissertação (Mestrado em Bioquímica) - Instituto de Ciências Básicas da Saúde, Universidade Federsl do Rio Grande do Sul.

LAZARIDOU, A.; BILIADERIS, C. G.; BACANDRITSOS, N.; SABATINI, A. G. Composition, thermal and rheological behaviour of selected Greek honeys. Journal of Food Engineering, v. 64, p. 9-21, 2004. 
LÉAUTÉ, R. Distillation in Alambic. Am. J. Enol. Vitic, v. 41, n. 1, p. 90-103, 1990.

LIMA, U. A. Aguardente - Fabricação em pequenas destilarias. Piracicaba: FEALQ, 1999. p. 96.

LIMA, U. A. Aguardentes. In: AQUARONE, E.; BORZANI, W.; SCHMIDELL, W.; LIMA, U. A. Biotecnologia Industrial: Biotecnologia na produção de alimentos, São Paulo: Editora Edgard Blucher. 2001. v. 4. p.145-182.

LIMA, U. A.; BASSO, L. C.; AMORIN, H. V. Produção de etanol. In: LIMA, U. A.; AQUARONE, E.; BORZANI, W.; SCHMIDELL, W. Biotecnologia industrial: Processos fermentativos e enzimáticos, São Paulo: Editora Edgard Blucher. 2001. v. 3. p. $1-43,2001$.

LiMA, A. J. B.; CARDOSO, M. G.; GUERREIRO, M. C.; PIMENTEL, A. Emprego do carvão ativado para remoção de cobre em cachaça. Química Nova, v. 29, p. 247-250, 2006.

LITCHEV, V. Influence of oxidation process on the development of the taste and flavor of wine distilates. American Journal of Enology and Viticulture, v. 40, n. 1, p. 31-35, 1989.

LUZ, S. Apicultura local busca espaço no mercado de Iguatemi. 23/06/2010. Disponível em: <http://www.iguatemi.ms.gov.br/view_noticias.htm?id=1096>. Acesso em: 16/07/2010.

MaCFIE H. J. H.; THOMSON D. M. H. Preference Mapping and Multidimensional Scaling. In: PIGGOT J.R., ed. Sensory Analysis of Foods, 2nd ed., Elsevier, London, 1988. 389p.

MaCFIE H. J. H.; THOMSON D. M. H. Measurement of food preferences. Local: Glasgow. Blackie Academic \& Professional, 1994. 310 p.

MAGALHÃES, K.T.; PEREIRA, G.V.M.; DIAS, D.R.; SCHWAN, R.F. Microbial communities and chemical changes during fermentation of sugary Brazilian kefir. World. Journal Microbiology Biotechnology, v. 33, p.1-10, 2010.

MAIA, A. B. et al. Tecnologia para produção de aguardente de qualidade. Belo Horizonte: Fundação Cristiano Otoni, 1994, 74 p. 
MAIA, A. B. R. A.; CAMPELO, E. A. P. Tecnologia da Cachaça de Alambique. Belo Horizonte: SEBRAE/MG, 2006.

MARCELLINI, P.S. Caracterização sensorial por perfil livre e análise tempo intensidade de suco de abacaxi (Ananas comosus (L.) Merril) reconstituído e adoçado com diferentes edulcorantes. Tese (Doutorado) - Universidade Estadual de Campinas. Faculdade de Engenharia de Alimentos. Campinas, SP. 2005. 85p.

MARINHO, A. V.; RODRIGUES, J. P. M. SIQUEIRA, M. I. D. Avaliação da acidez volátil, teor alcoólico e de cobre em cachaças artesanais. Estudos, Goiânia, v. 36, n.1/2, p. 75-93, 2009.

MARTÍNEZ, R. G. et al. Evolucion de los parâmetros físico-quimicos em aguardientes macerados com madera de roble: influencia del tiempo de maceración. Alimentaria, $\mathrm{n}$. 284, p. 111-117, 1997.

MASSON, J. Parâmetros físico-químicos e cromatográficos em aguardentes de cana queimada e não queimada. Lavras, 2005. 79 p. Dissertação (Mestrado em Ciência dos Alimentos), Universidade Federal de Lavras.

MASSON, J.; CARDOSO, M. G.; VILELA, F. J.; PIMENTEL, F. A.; MORAIS, A. R.; ANJOS, J. P. Parâmetros físico-químicoa e cromatográficos em aguardentes de cana queimada e não queimada. Ciência e Agrotecnologia, v. 31, n. 6, p. 1805-1810, 2007.

McINTYRE, A. C.; BILYK, M. L.; NORDON, A.; COLQUHOUN, G.; LITTLEJOHN, D. Detection of counterfeit Scotch whisky samples using mid-infrared spectrometry with an attenuated total reflectance probe incorporating polycrystalline silver halide fibres. Analytica Chimica Acta, v. 690, p. 228-233, 2011.

McKIBBEN, J., ENGESETH, N. J. Honey as a protective agent against lipid oxidation in ground turkey. Journal of Agricultural and Food Chemistry, v. 50, p. 592-595, 2002.

McNAMEE, C;. NOCI, F.; CRONIN, D. A.; LYNG, J. G.; MORGAN, D. J.; SCANNELL, A. G. M. PEF based hurdle strategy to control Pichia fermentans, Listeria innocua and Escherichia coli $\mathrm{k} 12$ in orange juice. International Journal of Food Microbiology, v. 138, p. $13-18,2010$.

MEILGAARD, M.; CIVILlE, G. V.; CARR, B. T. Consumer test and in-house panel acceptance tests. In: MEILGAARD, M.; CIVILLE, G. V.; CARR, B. T. (Eds) Sensory Evaluation Techniques. Florida: CRC, 1988. p. 119-141. 
MELLO, A. C. E. Obtenção de a olefinas em reações de oligomerização do eteno utilizando complexos de níquel em meio homegêneo e bifásico. Porto Alegre, 2005. 56 p. Dissertação (Mestrado em Química) - Instituto de Química, Universidade Federal do Rio Grande do Sul.

MENDES, E.; PROENÇA, E. B.; FERREIRA, I. M. P. L. V. O.; FERREIRA, M. A. Quality evaluation of Portuguese honey. Carbohydrate Polymers, v. 37, p. 219-223, 1998.

MENDONÇA, A. T. Identificação e estudo das características fisiológicas de saccharomyces cerevisiae presentes em fermentação espontânea de cana-de-açúcar. Lavras, 1999, 69 p. Dissertação (Mestrado em Ciências dos Alimentos). Universidade Federal de Lavras.

MINITAB - Minitab Statistical Software. Version 14; Minitab Inc, Pensilvânia, 2006.

MIRANDA, M. B.; HORII, J.; ALCARDE, A. R. Estudo do efeito da irradiação gamma $\left({ }^{60} \mathrm{CO}\right)$ na qualidade da cachaça e no tonel de envelhecimento. Ciência e Tecnologia de Alimentos, v. 26, n. 4, p. 772-778, 2006.

MIRANDA, M. B.; MARTINS, N. G. S.; BELlUCO, A. E. S.; HORII, J.; ALCARDE, A. R. Qualidade química de cachaças e de aguardentes brasileiras. Ciência e Tecnologia de Alimentos, v. 27, n. 4, p. 897-901, 2007.

MIRANDA M. B.; MARTINS, N. G. S.; BELlUCO E. S.; HORII, J.; ALCARDE, A. R. Perfil Físico Químico de aguardente durante envelhecimento em tonéis de carvalho. Ciência e Tecnologia de Alimentos, v. 28, p. 84-89, 2008.

MOITA NETO, J. M.; MOITA, G. C. Uma introdução à análise exploratória de dados multivariados. Química nova, v. 21, n. 4, p. 467-469, 1998.

MOLAN, P. C., RUSSELL, K. M. Non-peroxide antibacterial activity in some New Zealand honeys. Journal of Apicultural Research, v.27, n.1, p. 62-7, 1988.

MORAIS, P. B.; ROSA, C. A.; LINARDI, V. R.; PATARO, C.; MAIA, A. B. R. A. Characterization and succession of yeast populations associated with spontaneous fermentations during the production of Brazilian sugar-cane aguardente. World Journal of Microbiology \& Biotechnology, v. 13, p. 241-243, 1997. 
MOREIRA, R. F. A., DE MARIA, C. A. B. Glicídios do mel. Química Nova, v. 24, n. 4, p. 516-525, 2001.

MOSEDALE, J. R.; PUECH, J. L. Wood maturation of distilled beverages. Trends in Food Science \& Technology, v. 9, n. 3, p. 95-101, 1998.

MOTA, D.; LUÍS, A. C. P. M. N.; CERVEIRA, O.; ANJOS, O.; CANAS, S.; CALDEIRA, I. Teores de metanol em aguardentes vínicas e bagaceiras portuguesas. In: SIMPÓSIO DE VITIVINICULTURA DO ALENTEJO, 8, 2010, Évora. Anais... Évora: [s/n], 2010. p. 437-445.

MOURA, D. C. Riqueza e abundância de abelhas em diferentes estágios de degradação da caatinga como indicadores ambientais no entorno da usina hidrelétrica de Xingó. Recife, 2003. 96 p. Dissertação (Mestrado em Gestão e Políticas Ambientais) - Universidade Federal de Pernambuco.

MUNHOZ, C. L., SILVA, F.C., VIANA, L. F., SILVA JÚNIOR, Z. P. S., RIBEIRO, G. F. A. Produção e análise de aceitação de cachaça de mexerica por teste afetivo. In: CONGRESSO BRASILEIRO DE CIÊNCIA E TECNOLOGIA DE ALIMENTOS, 20, 2006, Curitiba. Anais... Curitiba: SBCTA, 2006. 1 CD-ROM.

MUNITIS, M. T.; CABRERA, E.; RODRIGUEZ-NAVARRO, A. An obligate osmophilic yeast from honey. Applied and Environmental Microbiology, v. 32, n. 3, p. 320-323, 1976.

NASCIMENTO, R. F.; MARQUES, J, C.; NETO, B. S. L.; DE KEUKELEIRE, D.; FRANCO, D. W. Qualitative and quantitative high-performance liquid chromatographic analysis of aldehydes in Brazilian sugar cane spirits and other distilled alcoholic beverages. J. Chromatogr. A, v. 782, p. 13-23, 1997.

NASCIMENTO, R. F.; BEZERRA, C. W.; FURUYA, S. M. B.; SCHULTZ, M. S.; POLASTRO, L. R.; LIMA-NETO, B. S.; FRANCO, D. W. Mineral profiles of Brazilian cachaças and other international spirits. J. Food Compos. Anal, v. 12, p. 17-25, 1999.

NICOL, D. A. Rum. In.: Lea, A. G. H.; Piggott, J. R. Fermented beverage productions. 2. ed. New York: Klumer Academic/Plenum Publishers, 2003. Cap 12, p.263-287.

NÓBREGA, I. C. C. Análise dos Compostos voláteis da Aguardente de Cana por Concentração Dinâmica do "Headspace" e Cromatografia Gasosa-Espectrometria de Massas. Ciência e Tecnologia de Alimentos, v. 23, n. 2, p. 210-216, 2003. 
NOVA, M. X. V.; SCHULER, A. R. P.; BRASILEIRO, B. T. R. V.; MORAIS JR., M. A. Yeast species involved in artisanal cachaça fermentation in three stills with different technological levels in Pernambuco, Brazil. Food Microbiology, v. 26, p. 460-466, 2009.

NOZAL, M. J.; BERNAL, J. L.; TORIBIO, L.; JIMÉNEZ J. J.; MARTÍN, M. T. Highperformance liquid chromatographic determination of methyl anthranilate, hydroxymethylfurfural and related compounds in honey. Journal of Chromatography A, v. 917, n. 1-2, p. 95-103, 2001.

ODDO, L. P.; PIRO, R. Main European unifloral honeys: descriptive sheets. Apidologie, v. 35, n. 1 , p. $38-81,2004$.

OLIVEIRA, E. S. Características fermentativas, formação de compostos voláteis e qualidade da aguardente de cana obtida por linhagens de leveduras isoladas de destilarias artesanais. 2001. 135 p. Tese (Doutorado em Tecnologia de Alimentos) Faculdade de Engenharia de Alimentos. Universidade Estadual de Campinas. Campinas. 2001.

PACHECO, T. F. Fermentação alcoólica com leveduras de características floculantes em reator tipo torre com escoamento ascendente. 2010. 107 p. Dissertação (Mestrado em Engenharia Química) - Faculdade de Engenharia Química, Universidade Federal de Uberlândia.

PADOVAN, F. C.; BORRAGINI, M. C. C.; FARIA, J. B. Efeito da circulação da aguardente de cana no tempo de envelhecimento em ancorotes de carvalho (Quercus SP). Alim. Nutr., Araraquara, v. 15, n. 3, p. 267-271, 2004.

PARAZZI, C.; ARTHUR, C. M.; LOPES, J. J. C.; BORGES, M. T. M. R. Avaliação e caracterização dos principais compostos químicos da aguardente de cana-de-açúcar envelhecida em tonéis de carvalho (Quercus sp.). Ciência e Tecnologia de Alimentos, v. 28, n. 1, p. 193-199, 2008.

PEDDIE, H. A. B. Ester formation in brewery fermentations. Journal of the Institute of Breweing, v. 96, p. 327-331, 1990.

PEREIRA, A. P.; DIAS, T.; ANDRADE, J.; RAMALHOSA, E.; ESTEVINHO, L. M. Mead production: Selection and characterization assays of Saccharomyces cerevisiae strains. Food and Chemical Toxicology, v. 47, p. 2057-2063, 2009. 
PEREIRA, F. M., LOPES, M. T. R., CAMARGO, R. C. R., VILELA, S. L. O. Produção de mel - comercialização, 2003. Disponível em: $<$ http://sistemasdeproducao.cnptia.embrapa.br/FontesHTML/Mel/SPMel/comercializacao. htm> Acesso em: 15/07/2010.

PHILLIPS, K. M.; CARLSEN, M. H.; BLOMHOFF, R. Total antioxidant content of alternatives to refined sugar. Journal of the American Dietetic Association, v. 109, p. 64 $71,2009$.

PIGGOTT, J. R.; CONNER, J. M. Whiskies. In: LEA, A. G. H.; PIGGOTT, J. R. Fermented beverage production. $2^{\text {nd }}$ ed. New York: Klumer Academic/Plenum Publishers, 2003. Cap 11, p. 239-262.

PINO, J. A. Characterization of rum using solid-phase microextraction with gas chromatography-mass spectrometry. Food Chemistry, v. 104, p. 421-428, 2007.

POLASTRO, L. R.; BOSO, L. M.; ANDRADE-SOBRINHO, L. G.; LIMA-NETO, B. S.; FRANCO, D. W. Compostos nitrogenados em bebidas estiladas: cachaça e tiquira. Ciência e Tecnologia de Alimentos, v. 21, n. 1, p. 78-81, 2001.

RACOWSKI, I., SILVAS, F. P. C., TAKUSHI, D. T. T., SILVA, D. W. G., MIRANDA, P. S. Ação antimicrobiana do mel em leite fermentado. Revista Analytica, n. 30, 2007.

RAGAZANI, A. V. F.; SCHOKEN-ITURRINO, R. P.; GARCIA, G. R.; DELFINO, T. P. C.; POIATTI, M. L.; BERCHIELLI, S, P. Esporos de Clostridium botulinum em mel comercializado no Estado de São Paulo e em outros Estados brasileiros. Ciência Rural, v.38, n.2, p.396-399, 2008.

REAZIN, G. H. Chemical mechanisms in whiskey maturation. American Journal of Enology and Viticulture, v. 32, n. 4, p. 283-289, 1981.

RIZZON, L. A.; ROSA, E. O.; SALVADOR, M. B. G.; ZUCCO, N. M. G. Características analíticas dos conhaques da microrregião homogênea vinicultora de Caxias do Sul. Ciência e Tecnologia de Alimentos, v. 12, n. 1, p. 43-51, 1992.

RODRIGUES, A.E.; SILVA, E.M.S.; BESERRA, E.M.F.; RODRIGUES, M.L. Análise físico-química dos méis das abelhas Apis mellifera e Melipona scutellaris produzidos em duas regiões no Estado da Paraíba. Ciência Rural, v. 35, n. 5, p. 1166-1171, 2005. 
ROTA, M. B. Efeito da Bidestilação na Qualidade Sensorial da Cachaça. Araraquara, 2008. 73 p. Dissertação (Mestre em Ciências de Alimentos). Faculdade de Ciências Farmacêuticas - Universidade Estadual paulista "Júlio de Mesquita Filho".

RUIZ-ARGUESO, T.; RODRIGUEZ-NAVARRO, A. Microbiology of ripening honey. Applied Microbiology, v. 30, n. 6, p. 893-896, 1975.

SAKAI, R. H. Cachaça. Brasília, 2010. Disponível em: $<$ http://www.agencia.cnptia.embrapa.br/gestor/cana-deacucar/arvore/CONT000fioglob502wyiv80z4s473agi63ul.html>. Acesso em: 09/05/ 2011.

SANTOS, G. S.; MARQUES, E. P.; SILVA, H. A. S.; BEZERRA, C. W. B.; MARQUES, A. B. Identificação e quantificação do cristal violeta em aguardentes de mandioca (tiquira). Química Nova. v. 28, n. 4, p. 583-586, 2005.

SARGENTELli, V.; MAURO, A. E.; MASSABNI, A. C. Aspectos do metabolismo do cobre no homem. Química Nova, Araraquara, v. 19, n. 3, p. 290-293, 1996.

SAS Institute. SAS User’s Guide: statistics. Cary, USA: SAS Inst., 2001.

SBRT. Serviço Brasileiro de Respostas Técnicas, 2010. Aguardente de mel. Disponível em: <http://www.sbrt.ibict.br>. Acesso em: 18/08/2010.

SCHWAN, R. F.; MENDONÇA, A. T.; SILVA JR., J. J.; RODRIGUES, V.; WHEALS, A. E. Microbiology and physiology of Cachaça (Aguardente) fermentations. Antonie van Leeuwenhoek, v. 79, p. 89-6, 2001.

SEBRAE - Serviço Brasileiro de Apoio às Micro e Pequenas Empresas, 2010. Exportação Brasileira de Mel, julho de 2010. Disponível em: $<$ http://www.sebrae.com.br/setor/apicultura/sobre-apicultura/mercado/exportacoes $>$. Acesso em: 19/08/2010.

SERAFIN, F. A. T. Ácidos orgânicos em aguardentes de cana de açúcar. São Cralos, 2010. 86 p. Dissertação (Mestre em Ciênicas - Química Analítica). Instituto de Químmica de São Carlos - Universidade de São Paulo.

SERRA, M. C. C. As Propriedades Antioxidantes do Mel. Centro de Estudos de Engenharia Química, Instituto Superior de Engenharia de Lisboa, 2007. 
SILVA, B. S.; VASCONCELOS, J. N. Envelhecimento de cachaça artesanal em tonéis de diversos tipos de madeira com 20L de capacidade. In: CONGRESSO BRASILEIRO DE ENGENHARIA QUÍMICA EM INICIAÇÃO CIENTÍFICA, 8., 2009, Uberlândia, Minas Gerais. Anais...Uberlândia: COBEQ IC, 2009.

SILVA, C. L.; QUEIROZ, A. J. M.; FIGUEIRÊDO, R. M. F. Caracterização físicoquímica de méis produzidos no Estado do Piauí para diferentes floradas. Revista Brasileira de Engenharia Agrícola e Ambiental, v.8, n.2/3, p. 260-265, 2004.

SILVA, L. M. F; PORTELA, A. L. O; ARAÚJO, A. D. A. Determinação do teor de álcool metílico (metanol) em amostras de cachaças vendidas na da região norte do ceará. In: CONGRESSO BRASILEIRO DE QUÍMICA, 47, 2007, Natal. CBA, 2007.

SILVA, M. B. L. et al. Hidrólise enzimática da polpa e qualidade físico-química de aguardente de banana refugo. In: CONGRESSO BRASILEIRO DE CIÊNCIA E TECNOLOGIA DE ALIMENTOS, 19, 2004, Recife. Anais... Recife: SBCTA, 2004. 1 CD-ROM.

SILVA, M. B. L.; CHAVES, J. B. P.; LELIS, V. G.; ALVARENGA, L. M.; ZUIM, D. R.; SILVA, P. H. A. Qualidade físico-química e sensorial de aguardentes de polpa de banana e banana integral submetidas à hidrólise enzimática. Alim. Nutr., v.20, n.2, p. 217-221, 2009.

SIlVA, P. H. A.; SANTOS, J. O.; ARAÚJO, L. D.; FARIA, F. C.; PEREIRA, A. F.; OLIVEIRA, V. A.; VICENTE, M. A.; BRANDÃO, R. L. Avaliação cromatográfica de compostos voláteis de cachaças produzidas com leveduras de diferentes procedências.

Ciênc. Tecnol. Aliment., v. 29, n. 1, p. 100-106, 2009.

SILVA, S. J. N.; SCHUCH, P. Z.; VAINSTEIN, M. H.; JABLONSKI, A. Determinação do 5-hidroximetilfurfural em méis utilizando cromatografia eletrocinética capilar micelar. Ciência e Tecnologia de Alimentos, v. 28, p. 46-50, 2008.

SILVA JÚNIOR, Z. P., VIANA, L. F., MUNHOZ, C. L., RIBEIRO, G. F. A., SILVA, F. C. Características físico-químicas da cachaça de abacaxi. In: CONGRESSO BRASILEIRO DE CIÊNCIA E TECNOLOGIA DE ALIMENTOS, 20, 2006, Curitiba. Anais... Curitiba: SBCTA, 2006. 1 CD-ROM.

SINGLETON, V. L. Maturation of wines and spirits: comparison, facts and hypotheses. American Journal of Enology and Viticulture, v. 46, p. 98-115, 1995. 
SMITH, S.M. PC-MDS Multidimensional Statistic Package, version 5.1. Provo, USA: Institute of Business MGT, Brightan Young University, Provo, UT. 1990.

SNOWDON, J. A.; CLIVER, D. O. Microorganisms in honey. International Journal of Food Microbiology, v. 31, p.1-26, 1996.

SODRÉ, G. S. Características fisico-químicas, microbiológicas e polínicas de amostras de méis de Apis mellifera L., 1758 (Hymenoptera: Apidae) dos estados do Ceará e Piauí. Piracicaba, 2005, 127 p. Tese (Doutorado em Ciências). Escola Superior de Agricultura Luiz de Queiróz, Universidade de São Paulo.

SOUZA, L. G.; LLISTÓ, A. M. S. M. Alguns componentes do coeficiente não álcool das aguardentes de cana: determinação por cromatografia de fase gasosa. Brasil Açucareiro, Rio de Janeiro, v. 91, n. 3, p. 109, 1978.

SOUZA, R. S.; CARNEIRO, J. G. M. Pesquisa de sujidades e matérias estranhas em mel de abelhas (Apis mellifera L.) Ciência e Tecnologia de Alimentos, v. 28, n. 1, p. 32-33, 2008.

SROKA, P.; TUSZYNSKI, T. Changes in organic acid contents during mead wort fermentation . Food Chemistry. v. 104, p. 1250-1257, 2007.

TAJIK, H.; JALALI, F. S. A.; JAVADI, S. Comparison of antibacterial activities of natural Urmia honey and penicillin derivatives: an in vitro study. Journal of Animal Veterinary Advances, v. 7, n. 9, p. 1097-1100, 2008.

TEIXIDÓ, E.; SANTOS, F. J.; PUIGNOU, L.; GALCERAN, M. T. Analysis of 5hydroxymethylfurfural in foods by gas chromatography-mass spectrometry. Journal of Chromatography A, v. 1135, p. 85-90, 2006.

TÉO, D.; DUARTE, R. M.; MUTTON, M. A.; MUTTON, M. J. R. Características físicoquímicas de aguardentes envelhecidas em barris confeccionados com diferentes madeiras. Científica, v.33, n.2, p. 152-159, 2005.

TESSARO, D.; LARSEN, A. C.; DALLAGO, R. C.; DAMASCENO, S. G.; SENE, L.; COELHO, S. R. M. Avaliação das fermentações alcoólica e acética para produção de vinagre a partir de suco de laranja. Acta Scientiarum Technology, v. 32, n. 2, p. 201-205, 2010 . 
TOMÁS-BARBERÁN, F. A., MARTOS, I., FERRERES F., RADOVIC, B. S., ANKLAM, E. HPLC flavonoid profiles as markers for the botanic origin of European unifloral honeys. Journal of the Science of Food and Agriculture, v. 81, p. 485-496, 2001.

TOSI, E.; CIAPPINI, M.; RÉ, E.; LUCERO, H. Honey thermal treatment effects on hydroxymethylfurfural content. Food Chemistry, v. 77, p. 71-74, 2002.

TRINDADE, J. L. F.; MEIRA, H. L.; BRASILEIRO, D. T.; OLIVEIRA, C. S.; GRDEN, L. Mel como substituto da glucose de milho em sorvetes. In: V SEMANA DE TECNOLOGIA EM ALIMENTOS, Universidade Tecnológica Federal do Paraná -Ponta Grossa, v. 02, n. 01, 21 a 25 de maio, 2007.

TURHAN, I.; TETIK, N.; KARHAN, M.; GUREL, F.; TAVUKCUOGLU, H. R. Quality of honeys influenced by thermal treatment. LWT, v. 41, p. 1396-1399, 2008.

VARGAS, E. A.; GLORIA, M. B. Qualidade da aguardente de cana (Saccharum officinarum, L.) produzida, comercializada e/ou engarrafada no Estado de Minas Gerais. Ciência e Tecnologia de Alimentos, v. 15, n. 1, p. 43-46, 1995.

VENTURINI, K. S.; SARCINELLI M. F.; SILVA, L. C. Características do mel. Boletim Técinico - $\quad$ PIE-UFES:01107, 2007. Disponível em: $<$ http://www.agais.com/telomc/b01107_caracteristicas_mel.pdf $>$. Acesso em: 27 out. 2011 .

VERSINI, G.; FRANCO, M. A.; MOSER, S.; BARCHETTI, P.; MANCA, G. Characterisation of apple distillates from native varieties of Sardinia island and comparison with other Italian products. Food Chemistry, v. 113, p. 1176-1183, 2009.

VORLOVA, L.; CELECHOVSKA, O. Activity of enzymes and trace element content in bee honey. Acta vet. Brno., Czech Republic, v.71, p.375-378, 2002.

WESTON, R. J.; MITCHELL, K. R.; ALLEN, K. L. Antibacterial phenolic components of New Zealand manuka honey. Food Chemistry, v. 64, p. 295-301, 1999.

WHITE JÚNIOR., J. W.; SUBERS, M. H. Studies on honey inhibine. 3. Effect of Heat. Journal of Apicultural Research, v. 3, n. 1, p. 45-50, 1964.

WHITE JÚNIOR., J. W.; RUDYJ, O. N. The protein content of honey. Journal of Apicultutal Research, v. 17, n. 4, p. 234-238, 1978. 
WINDHOLZ, M. The Merck Index. Rahway: Merck, 1976.

YEPES, B., ESPINOSA, M., LÓPEZ, S., BOLAÑOS, G. 2002. Producing antioxidant fractions from herbaceous matrices by supercritical fluid extraction. Fluid Phase Equilibria, v. 194-197, p. 879-884, 2002. 
APÊNDICES 

APÊNDICE A. Descrição das frações "cabeça", "coração"e "cauda" obtidas nas cinco bateladas realizadas para a obtenção de aguardente de mel.

Tabela 14 - Descrição das frações "cabeça", "coração"e "cauda" obtidas nas cinco bateladas realizadas para a obtenção de aguardente de mel.

\begin{tabular}{|c|c|c|c|c|c|c|c|c|c|c|}
\hline 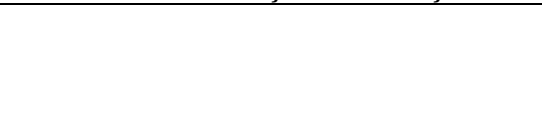 & \multicolumn{2}{|c|}{$\begin{array}{l}\text { Batelada } 1 \\
\text { Alambique }\end{array}$} & \multicolumn{2}{|c|}{$\begin{array}{l}\text { Batelada } 2 \\
\text { Alambique }\end{array}$} & \multicolumn{2}{|c|}{$\begin{array}{l}\text { Batelada } 3 \\
\text { Alambique }\end{array}$} & \multicolumn{2}{|c|}{$\begin{array}{c}\text { Batelada } \\
\text { Alambique }\end{array}$} & \multicolumn{2}{|c|}{$\begin{array}{l}\text { Batelada } \\
\text { Alambique }\end{array}$} \\
\hline & 1 & 2 & 1 & 2 & 1 & 2 & 1 & 2 & 1 & 2 \\
\hline Vol "cabeça" [L] & 0,520 & 0,500 & 1,500 & 3,530 & 1,500 & 1,5 & 1,320 & 1,100 & 2,240 & 1,500 \\
\hline Teor alcoólico “cabeça” $\left[{ }^{\circ} \mathrm{GL}\right]$ & 66,5 & 66,0 & 62,5 & 66,0 & 62,2 & 65,0 & 61,5 & 61,5 & 65,8 & 62,5 \\
\hline Vol “coração” [mL] & 17,900 & 15,000 & 17,500 & 20,800 & 21,470 & 21,430 & 19,220 & 20,490 & 20,000 & 20,850 \\
\hline Teor alcoólico "coração" [ [ GL] & 44,0 & 44,5 & 44,2 & 44,1 & 44,5 & 43,1 & 44,4 & 44,2 & 44,6 & 44,1 \\
\hline
\end{tabular}



ANEXOS 



\section{ANEXO A: Padrões de Identidade e Qualidade para Aguardente de Cana e Aguardente de Frutas}

Tabela 15 - Padrões de identidade e qualidade para aguardente de cana e para cachaça (BRASIL, 2005).

\begin{tabular}{|l|c|c|c|}
\hline \multicolumn{1}{|c|}{ Unidade } & Componente & Mínimo & Máximo \\
\hline & & 38 & 54 \\
\hline Graduação alcoólica & \% em volume & - & 150 \\
\hline Acidez volátil, em ácido acético & $\mathrm{mg} / 100 \mathrm{~mL}$ álcool anidro & - & 200 \\
\hline Ésteres, em acetato de etila & $\mathrm{mg} / 100 \mathrm{~mL}$ álcool anidro & - & 30 \\
\hline Aldeídos, em aldeído acético & $\mathrm{mg} / 100 \mathrm{~mL}$ álcool anidro & - & 360 \\
\hline Furfural + hidroximetilfurfural & $\mathrm{mg} / 100 \mathrm{~mL}$ álcool anidro & - & 650 \\
\hline Álcoois superiores* & $\mathrm{mg} / 100 \mathrm{~mL}$ álcool anidro & 200 & 20 \\
\hline Congêneres** & $\mathrm{mg} / 100 \mathrm{~mL}$ álcool anidro & - & 5 \\
\hline Álcool metílico & $\mathrm{mg} / 100 \mathrm{~mL}$ álcool anidro & - & $6^{* * *}$ \\
\hline Cobre & $\mathrm{mg} / \mathrm{L}$ & - & 5 \\
\hline Extrato seco & $\mathrm{g} / \mathrm{L}$ & - & \multicolumn{2}{c|}{} \\
\hline
\end{tabular}

*Álcoois superiores $=($ isobutílico + isoamílicos $+\mathrm{n}$-propílico $) ; *$ Congêneres $=($ acidez volátil + ésteres + aldeídos + Furfural/hidroximetilfurfural + álcoois superiores); e ***Aguardente de cana ou cachaça "adoçada" = máximo 30 g.L-1.

Tabela 16 - Padrões de identidade e qualidade para aguardente de frutas (BRASIL, 2008).

\begin{tabular}{|l|c|c|c|}
\hline \multicolumn{1}{|c|}{ Unidade } & Componente & Mínimo & Máximo \\
\hline & & 36 & 54 \\
\hline Graduação alcoólica & \% em volume & - & 100 \\
\hline Acidez volátil, em ácido acético & $\mathrm{mg} / 100 \mathrm{~mL}$ álcool anidro & - & 250 \\
\hline Ésteres, em acetato de etila & $\mathrm{mg} / 100 \mathrm{~mL}$ álcool anidro & - & 30 \\
\hline Aldeídos, em aldeído acético & $\mathrm{mg} / 100 \mathrm{~mL}$ álcool anidro & - & 360 \\
\hline Furfural & $\mathrm{mg} / 100 \mathrm{~mL}$ álcool anidro & - & 650 \\
\hline Álcool superior & $\mathrm{mg} / 100 \mathrm{~mL}$ álcool anidro & 200 & 20 \\
\hline Congêneres & $\mathrm{mg} / 100 \mathrm{~mL}$ álcool anidro & - & 5 \\
\hline Álcool metílico & $\mathrm{mg} / 100 \mathrm{~mL}$ álcool anidro & - & \\
\hline Cobre & $\mathrm{mg} / \mathrm{L}$ & & \\
\hline
\end{tabular}



ANEXO B: Vista geral dos alambiques da Associação Rural de Canas

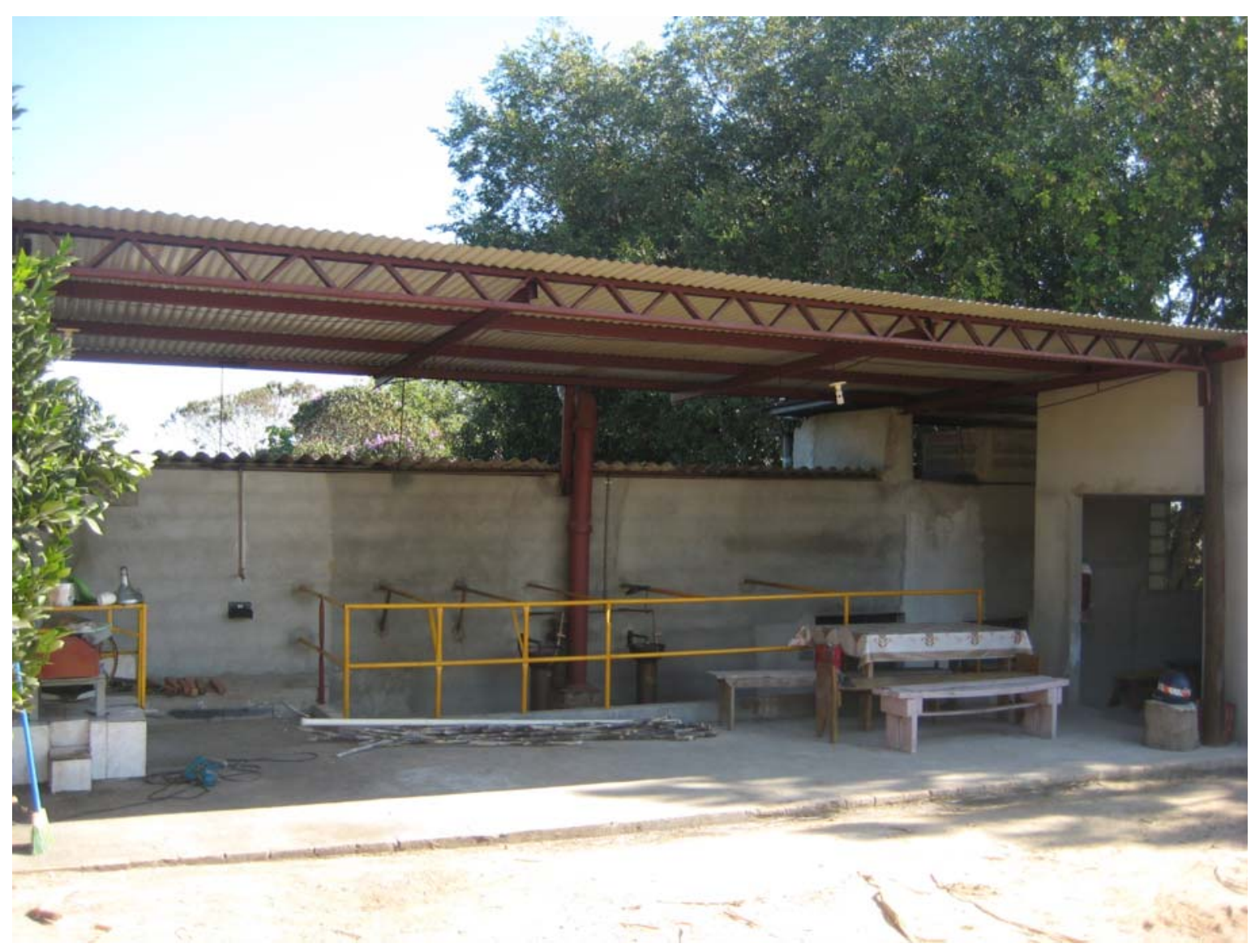

Figura 6 - Vista geral dos alambiques da Associação Rural de Canas. 

ANEXO C. Laudos das Análises fisico-químicas da aguardente de mel. 



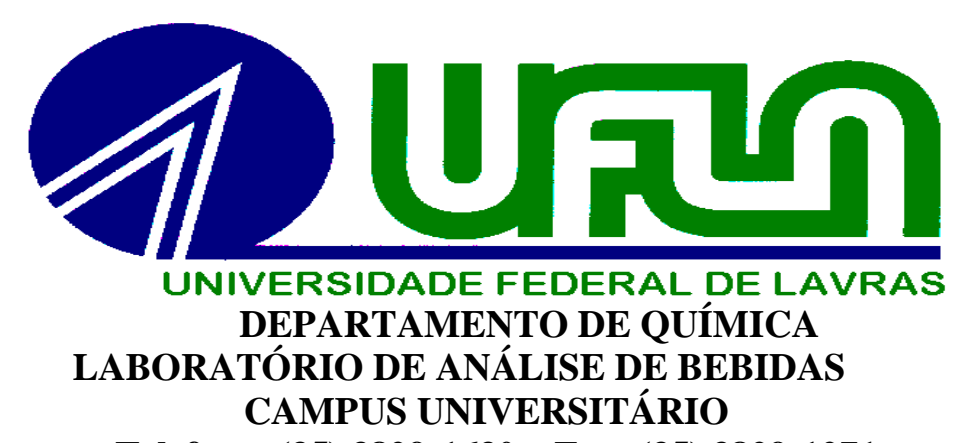

Telefone: (35) 3829-1630 - Fax: (35) 3829-1271

Caixa Postal, 3037 - CEP: 37200-000 - Lavras - Minas Gerais

CERTIFICADO DE ANÁLISE N: 4/2011

Amostra de: Aguardente de Mel, marca: -x-, lote: -x-, tipo: Simples, produzida e/ou engarrafada por: A/C Prof. Dr. Ismael Maciel de Mancilha, endereço: Escola de Engenharia de Lorena - EEL/USP Departamento de Biotecnologia, na cidade e/ou município de: Lorena, no estado de: SP, que deu entrada neste laboratório em:17/2/2011.

\begin{tabular}{|c|c|c|}
\hline Itens Analisados & Resultados & $\begin{array}{c}\text { Limite } \\
\text { Máximo }\end{array}$ \\
\hline 1. Exame Organoléptico & Normal & $-x-$ \\
\hline 2. Densidade Relativa $\left(20 / 20^{\circ} \mathrm{C}\right)$ & 0,94427 & $-\mathrm{x}-$ \\
\hline 3. $\quad$ Cobre $(\mathrm{mg} / \mathrm{L})$ & 5,21 & $\mathbf{5 , 0}$ \\
\hline 4. Extrato Seco a $100^{\circ} \mathrm{C}(\mathrm{g} / \mathrm{L})$ & 0,136 & $-\mathrm{X}-$ \\
\hline 5. Grau Alcoólico Real a $20^{\circ} \mathrm{C}(\% \mathrm{~V} / \mathrm{V})$ & 43,22 & 54,0 \\
\hline 6. Acidez Volátil em Ácido Acético (mg/100mL de Álcool Anidro) & 34,69 & $\mathbf{1 5 0 , 0}$ \\
\hline 7. Álcool Superior $(\mathrm{mg} / 100 \mathrm{~mL}$ de Álcool Anidro) & 169,61 & $\mathbf{3 6 0 , 0}$ \\
\hline 8. Furfural $(\mathrm{mg} / 100 \mathrm{~mL}$ de Álcool Anidro) & 1,90 & 5,0 \\
\hline 9. Aldeídos em Aldeído Acético (mg/100mL de Álcool Anidro) & 44,30 & 30,0 \\
\hline 10. Ésteres em Acetato de Etila (mg/100mL de Álcool Anidro) & 16,14 & 200,0 \\
\hline 11. Soma dos Componentes Secundários (mg/100mL de Álcool Anidro) & 266,64 & 650,0 \\
\hline 12. Álcool Metílico (mg/100mL de Álcool Anidro) & 6,77 & 20,0 \\
\hline 13. Açúcares Totais (g/L em Sacarose) - Aguardente Simples & $-\mathrm{x}-$ & $\leq 6,0$ \\
\hline 14. Açúcares Totais (g/L em Sacarose) - Aguardente Adoçada & $-\mathrm{x}-$ & $\leq 30,0$ \\
\hline
\end{tabular}

* D.O.I. - Seçẫo 1 - Ediçẫo número 124 de 30/06/2005: MAPA, Instruçẫo Normativa n 13 de 29/06/2005.

Notas:

1. A presente análise tem valor restrito à amostra recebida no Laboratório.

2. A identificação das amostras é de exclusiva responsabilidade do remetente.

3. Referência bibliográfica do método utilizado: MAPA/DAS/CGAL - Manual de Métodos de Análises de Bebidas e Vinagres (met.

$1,5,10,12,13,16,19,24)$.

4. Método utilizado TC01 e TC02 (Documento do Sistema de Qualidade do LAFQA).

Obs: Luanda - Amostra 1 - Primeira batelada/alambique 1

Conclusão: A amostra analisada não atende aos PIQ's para aguardente de mel.

$$
\text { Marvei das Ancrean Candoso }
$$

Maria das Graças Cardoso CRQ $02100835-2^{\mathrm{a}}$ REGIÃO/BH Coordenadora do LAB-UFLA/MG 


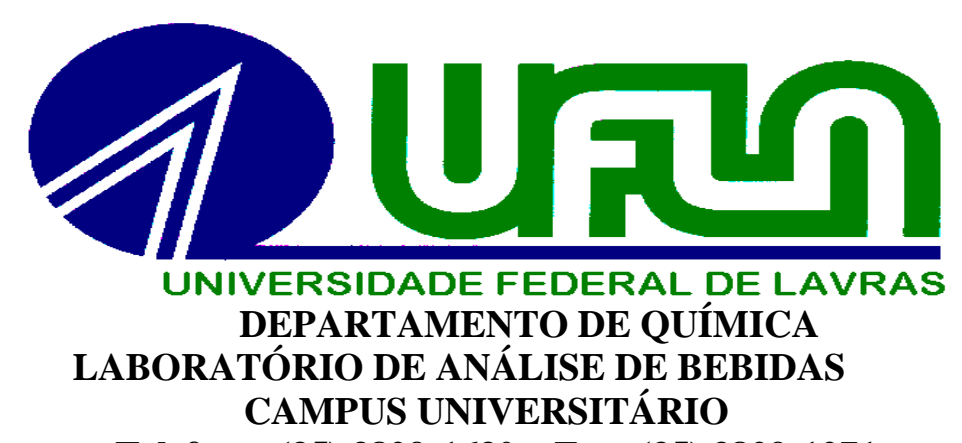

Telefone: (35) 3829-1630 - Fax: (35) 3829-1271

Caixa Postal, 3037 - CEP: 37200-000 - Lavras - Minas Gerais

CERTIFICADO DE ANÁLISE No: 5/2011

Amostra de: Aguardente de Mel, marca: -x-, lote: -x-, tipo: Simples, produzida e/ou engarrafada por: A/C Prof. Dr. Ismael Maciel de Mancilha, endereço: Escola de Engenharia de Lorena - EEL/USP Departamento de Biotecnologia, na cidade e/ou município de: Lorena, no estado de: SP, que deu entrada neste laboratório em:17/2/2011.

\begin{tabular}{|c|c|c|}
\hline Itens Analisados & Resultados & $\begin{array}{l}\text { Limite } \\
\text { Máximo }\end{array}$ \\
\hline 1. Exame Organoléptico & Normal & $-\mathrm{x}-$ \\
\hline 2. Densidade Relativa $\left(20 / 20^{\circ} \mathrm{C}\right)$ & 0,94430 & $-\mathrm{x}-$ \\
\hline 3. $\quad$ Cobre $(\mathrm{mg} / \mathrm{L})$ & 5,21 & 5,0 \\
\hline 4. Extrato Seco a $100^{\circ} \mathrm{C}(\mathrm{g} / \mathrm{L})$ & 0,144 & $-\mathrm{x}-$ \\
\hline 5. Grau Alcoólico Real a $20^{\circ} \mathrm{C}(\% \mathrm{~V} / \mathrm{V})$ & 43,22 & $\mathbf{5 4 , 0}$ \\
\hline 6. Acidez Volátil em Ácido Acético (mg/100mL de Álcool Anidro) & 34,69 & 150,0 \\
\hline 7. Álcool Superior $(\mathrm{mg} / 100 \mathrm{~mL}$ de Álcool Anidro) & 173,09 & $\mathbf{3 6 0 , 0}$ \\
\hline 8. Furfural $(\mathrm{mg} / 100 \mathrm{~mL}$ de Álcool Anidro) & 1,33 & 5,0 \\
\hline 9. Aldeídos em Aldeído Acético (mg/100mL de Álcool Anidro) & 44,30 & $\mathbf{3 0 , 0}$ \\
\hline 10. Ésteres em Acetato de Etila (mg/100mL de Álcool Anidro) & 16,14 & 200,0 \\
\hline 11. Soma dos Componentes Secundários (mg/100mL de Álcool Anidro) & 269,55 & 650,0 \\
\hline 12. Álcool Metílico (mg/100mL de Álcool Anidro) & 6,77 & $\mathbf{2 0 , 0}$ \\
\hline 13. Açúcares Totais ( $\mathrm{g} / \mathrm{L}$ em Sacarose) - Aguardente Simples & $-\mathrm{x}-$ & $\leq 6,0$ \\
\hline 14. Açúcares Totais (g/L em Sacarose) - Aguardente Adoçada & $-\mathrm{X}-$ & $\leq \mathbf{3 0 , 0}$ \\
\hline
\end{tabular}

* D.O.I. - Seçẫo 1 - Ediçấo número 124 de 30/06/2005: MAPA, Instruçâo Normativa nº 13 de 29/06/2005.

Notas:

1. A presente análise tem valor restrito à amostra recebida no Laboratório.

2. A identificação das amostras é de exclusiva responsabilidade do remetente.

3. Referência bibliográfica do método utilizado: MAPA/DAS/CGAL - Manual de Métodos de Análises de Bebidas e Vinagres (met.

$1,5,10,12,13,16,19,24)$.

4. Método utilizado TC01 e TC02 (Documento do Sistema de Qualidade do LAFQA).

Obs: Luanda - Amostra 2 - Primeira batelada/alambique 2

Conclusão: A amostra analisada não atende aos PIQ’s para aguardente de mel.

$$
\text { Marier das Ancucas Candoso }
$$

Maria das Graças Cardoso CRQ $02100835-2^{\mathrm{a}}$ REGIÃO/BH Coordenadora do LAB-UFLA/MG 


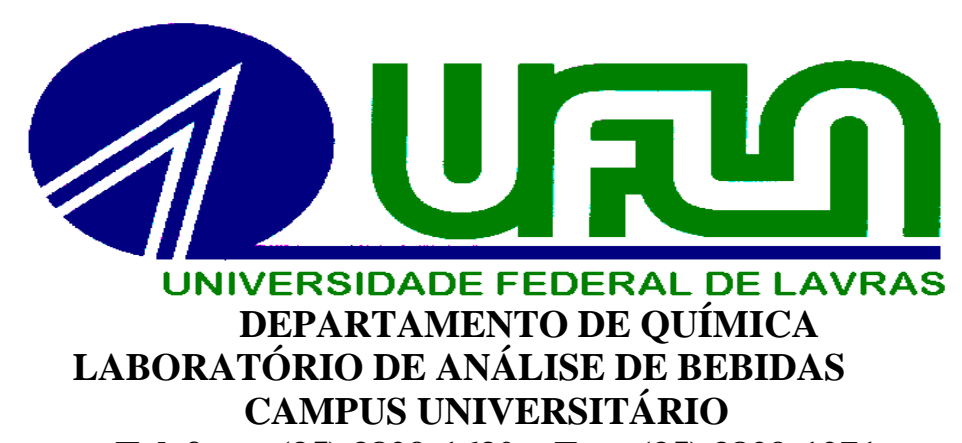

Telefone: (35) 3829-1630 - Fax: (35) 3829-1271

Caixa Postal, 3037 - CEP: 37200-000 - Lavras - Minas Gerais

CERTIFICADO DE ANÁLISE No: 6/2011

Amostra de: Aguardente de Mel, marca: -x-, lote: -x-, tipo: Simples, produzida e/ou engarrafada por: A/C Prof. Dr. Ismael Maciel de Mancilha, endereço: Escola de Engenharia de Lorena - EEL/USP Departamento de Biotecnologia, na cidade e/ou município de: Lorena, no estado de: SP, que deu entrada neste laboratório em:17/2/2011.

\begin{tabular}{|c|c|c|}
\hline Itens Analisados & Resultados & $\begin{array}{l}\text { Limite } \\
\text { Máximo }\end{array}$ \\
\hline 1. Exame Organoléptico & Normal & $-\mathrm{x}-$ \\
\hline 2. Densidade Relativa $\left(20 / 20^{\circ} \mathrm{C}\right)$ & 0,94257 & $-\mathrm{x}-$ \\
\hline 3. $\quad$ Cobre $(\mathrm{mg} / \mathrm{L})$ & 2,74 & 5,0 \\
\hline 4. Extrato Seco a $100^{\circ} \mathrm{C}(\mathrm{g} / \mathrm{L})$ & 0,096 & $-\mathrm{x}-$ \\
\hline 5. Grau Alcoólico Real a $20^{\circ} \mathrm{C}(\% \mathrm{~V} / \mathrm{V})$ & 44,21 & 54,0 \\
\hline 6. Acidez Volátil em Ácido Acético (mg/100mL de Álcool Anidro) & 23,74 & 150,0 \\
\hline 7. Álcool Superior $(\mathrm{mg} / 100 \mathrm{~mL}$ de Álcool Anidro) & 143,84 & $\mathbf{3 6 0 , 0}$ \\
\hline 8. Furfural $(\mathrm{mg} / 100 \mathrm{~mL}$ de Álcool Anidro) & 1,90 & 5,0 \\
\hline 9. Aldeídos em Aldeído Acético (mg/100mL de Álcool Anidro) & 7,45 & $\mathbf{3 0 , 0}$ \\
\hline 10. Ésteres em Acetato de Etila (mg/100mL de Álcool Anidro) & 9,86 & 200,0 \\
\hline 11. Soma dos Componentes Secundários (mg/100mL de Álcool Anidro) & 186,79 & 650,0 \\
\hline 12. Álcool Metílico (mg/100mL de Álcool Anidro) & 5,80 & $\mathbf{2 0 , 0}$ \\
\hline 13. Açúcares Totais ( $\mathrm{g} / \mathrm{L}$ em Sacarose) - Aguardente Simples & $-\mathrm{x}-$ & $\leq 6,0$ \\
\hline 14. Açúcares Totais (g/L em Sacarose) - Aguardente Adoçada & $-\mathrm{X}-$ & $\leq \mathbf{3 0 , 0}$ \\
\hline
\end{tabular}

* D.O.I. - Seçẫo 1 - Ediçấo número 124 de 30/06/2005: MAPA, Instruçâo Normativa nº 13 de 29/06/2005.

Notas:

1. A presente análise tem valor restrito à amostra recebida no Laboratório.

2. A identificação das amostras é de exclusiva responsabilidade do remetente.

3. Referência bibliográfica do método utilizado: MAPA/DAS/CGAL - Manual de Métodos de Análises de Bebidas e Vinagres (met.

$1,5,10,12,13,16,19,24)$.

4. Método utilizado TC01 e TC02 (Documento do Sistema de Qualidade do LAFQA).

Obs: Luanda - Amostra 3 - Segunda batelada/ alambique 1

Conclusão: A amostra analisada não atende aos PIQ’s para aguardente de mel.

$$
\text { Marrir das Cracen Candoso }
$$

Maria das Graças Cardoso CRQ $02100835-2^{\mathrm{a}}$ REGIÃO/BH Coordenadora do LAB-UFLA/MG 


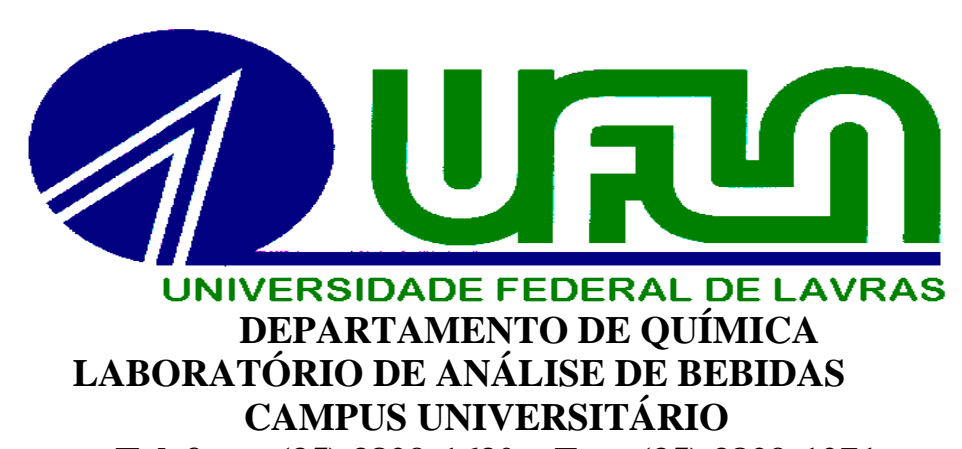

Telefone: (35) 3829-1630 - Fax: (35) 3829-1271

Caixa Postal, 3037 - CEP: 37200-000 - Lavras - Minas Gerais

CERTIFICADO DE ANÁLISE No: 7/2011

Amostra de: Aguardente de Mel, marca: -x-, lote: -x-, tipo: Simples, produzida e/ou engarrafada por: A/C Prof. Dr. Ismael Maciel de Mancilha, endereço: Escola de Engenharia de Lorena - EEL/USP Departamento de Biotecnologia, na cidade e/ou município de: Lorena, no estado de: SP, que deu entrada neste laboratório em:17/2/2011.

\begin{tabular}{|c|c|c|}
\hline Itens Analisados & Resultados & $\begin{array}{c}\text { Limite } \\
\text { Máximo }\end{array}$ \\
\hline 1. Exame Organoléptico & Normal & $-x-$ \\
\hline 2. Densidade Relativa $\left(20 / 20^{\circ} \mathrm{C}\right)$ & 0,94270 & $-\mathrm{x}-$ \\
\hline 3. $\quad$ Cobre $(\mathrm{mg} / \mathrm{L})$ & 3,64 & $\mathbf{5 , 0}$ \\
\hline 4. Extrato Seco a $100^{\circ} \mathrm{C}(\mathrm{g} / \mathrm{L})$ & 0,116 & $-\mathrm{X}-$ \\
\hline 5. Grau Alcoólico Real a $20^{\circ} \mathrm{C}(\% \mathrm{~V} / \mathrm{V})$ & 44,14 & 54,0 \\
\hline 6. Acidez Volátil em Ácido Acético (mg/100mL de Álcool Anidro) & 27,17 & $\mathbf{1 5 0 , 0}$ \\
\hline 7. Álcool Superior $(\mathrm{mg} / 100 \mathrm{~mL}$ de Álcool Anidro) & 165,76 & $\mathbf{3 6 0 , 0}$ \\
\hline 8. Furfural $(\mathrm{mg} / 100 \mathrm{~mL}$ de Álcool Anidro) & 1,57 & 5,0 \\
\hline 9. Aldeídos em Aldeído Acético (mg/100mL de Álcool Anidro) & 12,52 & 30,0 \\
\hline 10. Ésteres em Acetato de Etila (mg/100mL de Álcool Anidro) & 18,77 & 200,0 \\
\hline 11. Soma dos Componentes Secundários (mg/100mL de Álcool Anidro) & 225,79 & 650,0 \\
\hline 12. Álcool Metílico (mg/100mL de Álcool Anidro) & 5,81 & 20,0 \\
\hline 13. Açúcares Totais (g/L em Sacarose) - Aguardente Simples & $-\mathrm{x}-$ & $\leq 6,0$ \\
\hline 14. Açúcares Totais (g/L em Sacarose) - Aguardente Adoçada & $-\mathrm{x}-$ & $\leq 30,0$ \\
\hline
\end{tabular}

* D.O.I. - Seçẫo 1 - Ediçâo número 124 de 30/06/2005: MAPA, Instruçâo Normativa no 13 de 29/06/2005.

Notas:

1. A presente análise tem valor restrito à amostra recebida no Laboratório.

2. A identificação das amostras é de exclusiva responsabilidade do remetente.

3. Referência bibliográfica do método utilizado: MAPA/DAS/CGAL - Manual de Métodos de Análises de Bebidas e Vinagres (met.

$1,5,10,12,13,16,19,24)$.

4. Método utilizado TC01 e TC02 (Documento do Sistema de Qualidade do LAFQA).

Obs: Luanda - Amostra 4 - Segunda batelada/alambique 2

Conclusão: A amostra analisada atende aos PIQ's para aguardente de mel.

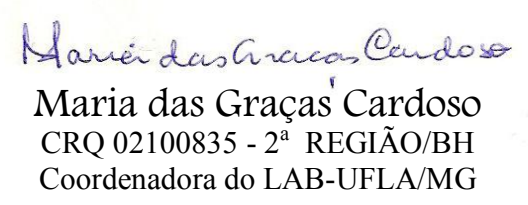




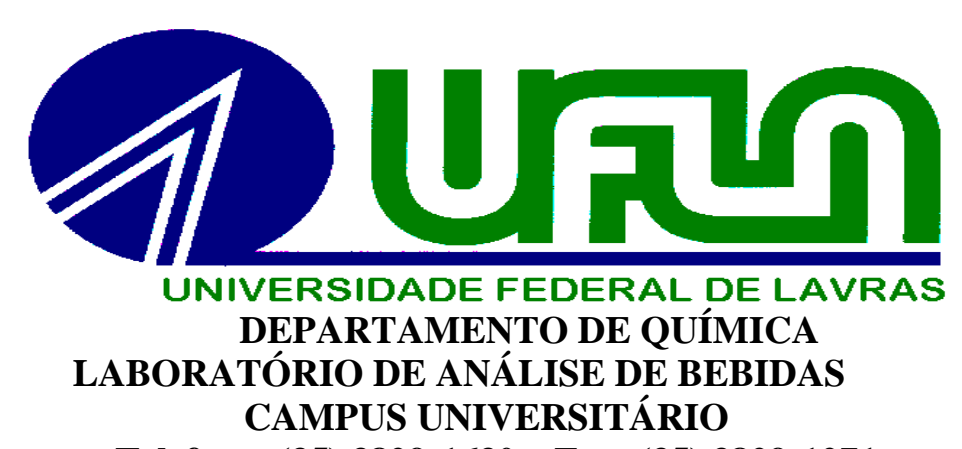

Telefone: (35) 3829-1630 - Fax: (35) 3829-1271

Caixa Postal, 3037 - CEP: 37200-000 - Lavras - Minas Gerais

CERTIFICADO DE ANÁLISE No: 8/2011

Amostra de: Aguardente de Mel, marca: -x-, lote: -x-, tipo: Simples, produzida e/ou engarrafada por: A/C Prof. Dr. Ismael Maciel de Mancilha, endereço: Escola de Engenharia de Lorena - EEL/USP Departamento de Biotecnologia, na cidade e/ou município de: Lorena, no estado de: SP, que deu entrada neste laboratório em:17/2/2011.

\begin{tabular}{|c|c|c|}
\hline Itens Analisados & Resultados & $\begin{array}{c}\text { Limite } \\
\text { Máximo }\end{array}$ \\
\hline 1. Exame Organoléptico & Normal & $-x-$ \\
\hline 2. Densidade Relativa $\left(20 / 20^{\circ} \mathrm{C}\right)$ & 0,94260 & $-\mathrm{x}-$ \\
\hline 3. Cobre $(\mathrm{mg} / \mathrm{L})$ & 1,23 & $\mathbf{5 , 0}$ \\
\hline 4. Extrato Seco a $100^{\circ} \mathrm{C}(\mathrm{g} / \mathrm{L})$ & 0,136 & $-\mathrm{X}-$ \\
\hline 5. Grau Alcoólico Real a $20^{\circ} \mathrm{C}(\% \mathrm{~V} / \mathrm{V})$ & 44,20 & 54,0 \\
\hline 6. Acidez Volátil em Ácido Acético (mg/100mL de Álcool Anidro) & 23,74 & $\mathbf{1 5 0 , 0}$ \\
\hline 7. Álcool Superior (mg/100mL de Álcool Anidro) & 185,03 & 360,0 \\
\hline 8. Furfural (mg/100mL de Álcool Anidro) & 1,25 & 5,0 \\
\hline 9. Aldeídos em Aldeído Acético (mg/100mL de Álcool Anidro) & 13,39 & 30,0 \\
\hline 10. Ésteres em Acetato de Etila (mg/100mL de Álcool Anidro) & 21,70 & 200,0 \\
\hline 11. Soma dos Componentes Secundários (mg/100mL de Álcool Anidro) & 245,11 & 650,0 \\
\hline 12. Álcool Metílico (mg/100mL de Álcool Anidro) & 5,80 & 20,0 \\
\hline 13. Açúcares Totais (g/L em Sacarose) - Aguardente Simples & $-\mathrm{x}-$ & $\leq 6,0$ \\
\hline 14. Açúcares Totais (g/L em Sacarose) - Aguardente Adoçada & $-\mathrm{x}-$ & $\leq \mathbf{3 0 , 0}$ \\
\hline
\end{tabular}

* D.O.I. - Seçẫo 1 - Ediçấo número 124 de 30/06/2005: MAPA, Instruçâo Normativa nº 13 de 29/06/2005.

Notas:

1. A presente análise tem valor restrito à amostra recebida no Laboratório.

2. A identificação das amostras é de exclusiva responsabilidade do remetente.

3. Referência bibliográfica do método utilizado: MAPA/DAS/CGAL - Manual de Métodos de Análises de Bebidas e Vinagres (met.

$1,5,10,12,13,16,19,24)$.

4. Método utilizado TC01 e TC02 (Documento do Sistema de Qualidade do LAFQA).

Obs: Luanda - Amostra 5 - Terceira batelada/alambique 1

Conclusão: A amostra analisada atende aos PIQ's para aguardente de mel. 


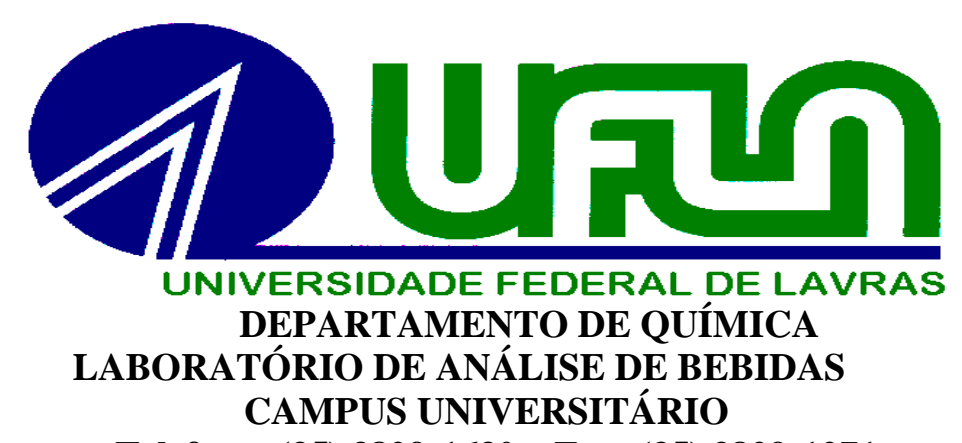

Telefone: (35) 3829-1630 - Fax: (35) 3829-1271

Caixa Postal, 3037 - CEP: 37200-000 - Lavras - Minas Gerais

CERTIFICADO DE ANÁLISE No: 9/2011

Amostra de: Aguardente de Mel, marca: -x-, lote: -x-, tipo: Simples, produzida e/ou engarrafada por: A/C Prof. Dr. Ismael Maciel de Mancilha, endereço: Escola de Engenharia de Lorena - EEL/USP Departamento de Biotecnologia, na cidade e/ou município de: Lorena, no estado de: SP, que deu entrada neste laboratório em:17/2/2011.

\begin{tabular}{|c|c|c|}
\hline Itens Analisados & Resultados & $\begin{array}{c}\text { Limite } \\
\text { Máximo }\end{array}$ \\
\hline 1. Exame Organoléptico & Normal & $-x-$ \\
\hline 2. Densidade Relativa $\left(20 / 20^{\circ} \mathrm{C}\right)$ & 0,94450 & $-\mathrm{x}-$ \\
\hline 3. Cobre $(\mathrm{mg} / \mathrm{L})$ & 2,64 & $\mathbf{5 , 0}$ \\
\hline 4. Extrato Seco a $100^{\circ} \mathrm{C}(\mathrm{g} / \mathrm{L})$ & 0,116 & $-\mathrm{X}-$ \\
\hline 5. Grau Alcoólico Real a $20^{\circ} \mathrm{C}(\% \mathrm{~V} / \mathrm{V})$ & 43,10 & 54,0 \\
\hline 6. Acidez Volátil em Ácido Acético (mg/100mL de Álcool Anidro) & 24,35 & $\mathbf{1 5 0 , 0}$ \\
\hline 7. Álcool Superior (mg/100mL de Álcool Anidro) & 186,58 & 360,0 \\
\hline 8. Furfural (mg/100mL de Álcool Anidro) & 1,74 & 5,0 \\
\hline 9. Aldeídos em Aldeído Acético (mg/100mL de Álcool Anidro) & 13,99 & 30,0 \\
\hline 10. Ésteres em Acetato de Etila (mg/100mL de Álcool Anidro) & 20,23 & 200,0 \\
\hline 11. Soma dos Componentes Secundários (mg/100mL de Álcool Anidro) & 246,89 & 650,0 \\
\hline 12. Álcool Metílico (mg/100mL de Álcool Anidro) & 8,73 & 20,0 \\
\hline 13. Açúcares Totais (g/L em Sacarose) - Aguardente Simples & $-\mathrm{x}-$ & $\leq 6,0$ \\
\hline 14. Açúcares Totais (g/L em Sacarose) - Aguardente Adoçada & $-\mathrm{x}-$ & $\leq \mathbf{3 0 , 0}$ \\
\hline
\end{tabular}

* D.O.I. - Seçẫo 1 - Ediçâo número 124 de 30/06/2005: MAPA, Instruçâo Normativa no 13 de 29/06/2005.

Notas:

1. A presente análise tem valor restrito à amostra recebida no Laboratório.

2. A identificação das amostras é de exclusiva responsabilidade do remetente.

3. Referência bibliográfica do método utilizado: MAPA/DAS/CGAL - Manual de Métodos de Análises de Bebidas e Vinagres (met.

$1,5,10,12,13,16,19,24)$.

4. Método utilizado TC01 e TC02 (Documento do Sistema de Qualidade do LAFQA).

Obs: Luanda - Amostra 6 - Terceira batelada/alambique 2

Conclusão: A amostra analisada atende aos PIQ’s para aguardente de mel.

Maria das Graças Cardoso CRQ $02100835-2^{\mathrm{a}}$ REGIÃO/BH Coordenadora do LAB-UFLA/MG 


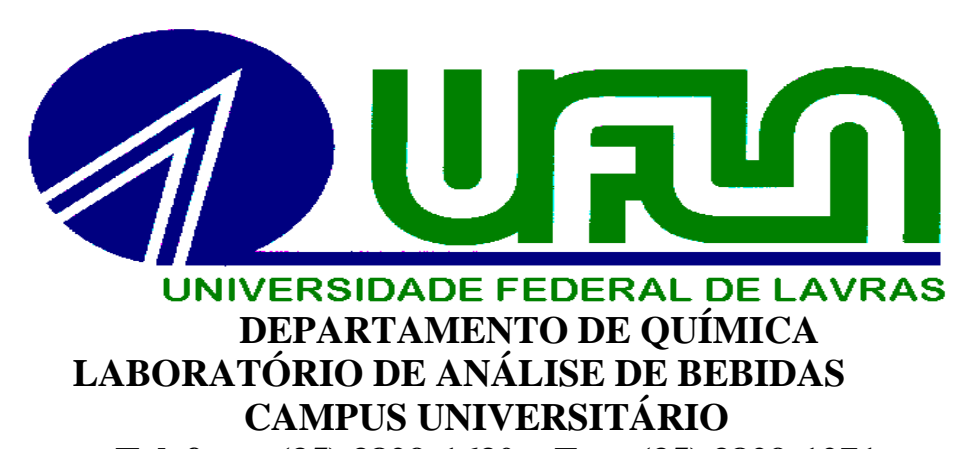

Telefone: (35) 3829-1630 - Fax: (35) 3829-1271

Caixa Postal, 3037 - CEP: 37200-000 - Lavras - Minas Gerais

CERTIFICADO DE ANÁLISE Nº: 10/2011

Amostra de: Aguardente de Mel, marca: -x-, lote: -x-, tipo: Simples, produzida e/ou engarrafada por: A/C Prof. Dr. Ismael Maciel de Mancilha, endereço: Escola de Engenharia de Lorena - EEL/USP Departamento de Biotecnologia, na cidade e/ou município de: Lorena, no estado de: SP, que deu entrada neste laboratório em:17/2/2011.

\begin{tabular}{|c|c|c|}
\hline Itens Analisados & Resultados & $\begin{array}{c}\text { Limite } \\
\text { Máximo }\end{array}$ \\
\hline 1. Exame Organoléptico & Normal & $-x-$ \\
\hline 2. Densidade Relativa $\left(20 / 20^{\circ} \mathrm{C}\right)$ & 0,94162 & $-\mathrm{x}-$ \\
\hline 3. $\quad$ Cobre $(\mathrm{mg} / \mathrm{L})$ & 2,19 & $\mathbf{5 , 0}$ \\
\hline 4. Extrato Seco a $100^{\circ} \mathrm{C}(\mathrm{g} / \mathrm{L})$ & 0,128 & $-\mathrm{X}-$ \\
\hline 5. Grau Alcoólico Real a $20^{\circ} \mathrm{C}(\% \mathrm{~V} / \mathrm{V})$ & 44,73 & 54,0 \\
\hline 6. Acidez Volátil em Ácido Acético (mg/100mL de Álcool Anidro) & 23,46 & $\mathbf{1 5 0 , 0}$ \\
\hline 7. Álcool Superior $(\mathrm{mg} / 100 \mathrm{~mL}$ de Álcool Anidro) & 184,37 & $\mathbf{3 6 0 , 0}$ \\
\hline 8. Furfural $(\mathrm{mg} / 100 \mathrm{~mL}$ de Álcool Anidro) & 2,20 & 5,0 \\
\hline 9. Aldeídos em Aldeído Acético (mg/100mL de Álcool Anidro) & 15,35 & 30,0 \\
\hline 10. Ésteres em Acetato de Etila (mg/100mL de Álcool Anidro) & 25,35 & 200,0 \\
\hline 11. Soma dos Componentes Secundários (mg/100mL de Álcool Anidro) & 250,73 & 650,0 \\
\hline 12. Álcool Metílico (mg/100mL de Álcool Anidro) & 4,89 & 20,0 \\
\hline 13. Açúcares Totais (g/L em Sacarose) - Aguardente Simples & $-x-$ & $\leq 6,0$ \\
\hline 14. Açúcares Totais (g/L em Sacarose) - Aguardente Adoçada & $-\mathrm{x}-$ & $\leq 30,0$ \\
\hline
\end{tabular}

* D.O.I. - Seçẫo 1 - Ediçấo número 124 de 30/06/2005: MAPA, Instruçâo Normativa nº 13 de 29/06/2005.

Notas:

1. A presente análise tem valor restrito à amostra recebida no Laboratório.

2. A identificação das amostras é de exclusiva responsabilidade do remetente.

3. Referência bibliográfica do método utilizado: MAPA/DAS/CGAL - Manual de Métodos de Análises de Bebidas e Vinagres (met.

$1,5,10,12,13,16,19,24)$.

4. Método utilizado TC01 e TC02 (Documento do Sistema de Qualidade do LAFQA).

Obs: Luanda - Amostra 7 - Quarta batelada/alambique 1

Conclusão: A amostra analisada atende aos PIQ’s para aguardente de mel.

Marvi das Cincuean Cudoso

Maria das Graças Cardoso

CRQ $02100835-2^{\mathrm{a}}$ REGIÃO/BH

Coordenadora do LAB-UFLA/MG 


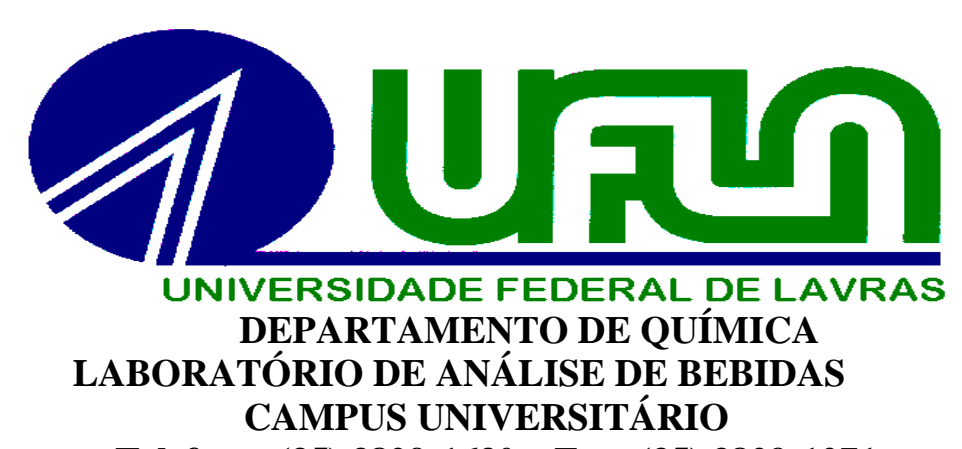

Telefone: (35) 3829-1630 - Fax: (35) 3829-1271

Caixa Postal, 3037 - CEP: 37200-000 - Lavras - Minas Gerais

CERTIFICADO DE ANÁLISE No: 11/2011

Amostra de: Aguardente de Mel, marca: -x-, lote: -x-, tipo: Simples, produzida e/ou engarrafada por: A/C Prof. Dr. Ismael Maciel de Mancilha, endereço: Escola de Engenharia de Lorena - EEL/USP Departamento de Biotecnologia, na cidade e/ou município de: Lorena, no estado de: SP, que deu entrada neste laboratório em:17/2/2011.

\begin{tabular}{|c|c|c|}
\hline Itens Analisados & Resultados & $\begin{array}{c}\text { Limite } \\
\text { Máximo }\end{array}$ \\
\hline 1. Exame Organoléptico & Normal & $-x-$ \\
\hline 2. Densidade Relativa $\left(20 / 20^{\circ} \mathrm{C}\right)$ & 0,94245 & $-\mathrm{x}-$ \\
\hline 3. $\quad$ Cobre $(\mathrm{mg} / \mathrm{L})$ & 2,66 & $\mathbf{5 , 0}$ \\
\hline 4. Extrato Seco a $100^{\circ} \mathrm{C}(\mathrm{g} / \mathrm{L})$ & 0,100 & $-\mathrm{X}-$ \\
\hline 5. Grau Alcoólico Real a $20^{\circ} \mathrm{C}(\% \mathrm{~V} / \mathrm{V})$ & 44,26 & 54,0 \\
\hline 6. Acidez Volátil em Ácido Acético (mg/100mL de Álcool Anidro) & 27,10 & $\mathbf{1 5 0 , 0}$ \\
\hline 7. Álcool Superior $(\mathrm{mg} / 100 \mathrm{~mL}$ de Álcool Anidro) & 196,21 & $\mathbf{3 6 0 , 0}$ \\
\hline 8. Furfural $(\mathrm{mg} / 100 \mathrm{~mL}$ de Álcool Anidro) & 1,05 & 5,0 \\
\hline 9. Aldeídos em Aldeído Acético (mg/100mL de Álcool Anidro) & 15,64 & 30,0 \\
\hline 10. Ésteres em Acetato de Etila (mg/100mL de Álcool Anidro) & 27,59 & 200,0 \\
\hline 11. Soma dos Componentes Secundários (mg/100mL de Álcool Anidro) & 267,59 & 650,0 \\
\hline 12. Álcool Metílico (mg/100mL de Álcool Anidro) & 4,35 & 20,0 \\
\hline 13. Açúcares Totais (g/L em Sacarose) - Aguardente Simples & $-\mathrm{x}-$ & $\leq 6,0$ \\
\hline 14. Açúcares Totais (g/L em Sacarose) - Aguardente Adoçada & $-\mathrm{x}-$ & $\leq 30,0$ \\
\hline
\end{tabular}

* D.O.I. - Seçẫo 1 - Ediçấo número 124 de 30/06/2005: MAPA, Instruçâo Normativa nº 13 de 29/06/2005.

Notas:

1. A presente análise tem valor restrito à amostra recebida no Laboratório.

2. A identificação das amostras é de exclusiva responsabilidade do remetente.

3. Referência bibliográfica do método utilizado: MAPA/DAS/CGAL - Manual de Métodos de Análises de Bebidas e Vinagres (met.

$1,5,10,12,13,16,19,24)$.

4. Método utilizado TC01 e TC02 (Documento do Sistema de Qualidade do LAFQA).

Obs: Luanda - Amostra 8 - Quarta batelada/alambique 2

Conclusão: A amostra analisada atende aos PIQ's para aguardente de mel. 


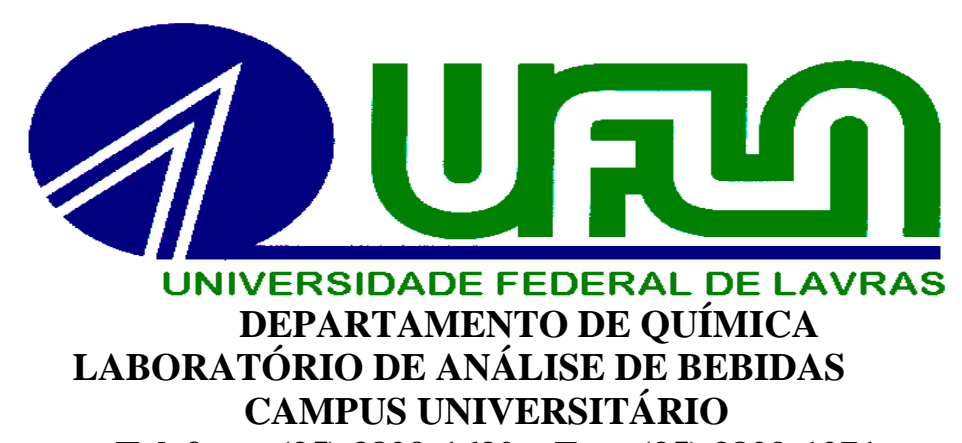

Telefone: (35) 3829-1630 - Fax: (35) 3829-1271

Caixa Postal, 3037 - CEP: 37200-000 - Lavras - Minas Gerais

CERTIFICADO DE ANÁLISE No: 12/2011

Amostra de: Aguardente de Mel, marca: -x-, lote: -x-, tipo: Simples, produzida e/ou engarrafada por: A/C Prof. Dr. Ismael Maciel de Mancilha, endereço: Escola de Engenharia de Lorena - EEL/USP Departamento de Biotecnologia, na cidade e/ou município de: Lorena, no estado de: SP, que deu entrada neste laboratório em:17/2/2011.

\begin{tabular}{|c|c|c|}
\hline Itens Analisados & Resultados & $\begin{array}{c}\text { Limite } \\
\text { Máximo }\end{array}$ \\
\hline 1. Exame Organoléptico & Normal & $-x-$ \\
\hline 2. Densidade Relativa $\left(20 / 20^{\circ} \mathrm{C}\right)$ & 0,94207 & $-\mathrm{x}-$ \\
\hline 3. $\quad$ Cobre $(\mathrm{mg} / \mathrm{L})$ & 2,05 & $\mathbf{5 , 0}$ \\
\hline 4. Extrato Seco a $100^{\circ} \mathrm{C}(\mathrm{g} / \mathrm{L})$ & 0,056 & $-\mathrm{X}-$ \\
\hline 5. Grau Alcoólico Real a $20^{\circ} \mathrm{C}(\% \mathrm{~V} / \mathrm{V})$ & 44,48 & 54,0 \\
\hline 6. Acidez Volátil em Ácido Acético (mg/100mL de Álcool Anidro) & 26,96 & $\mathbf{1 5 0 , 0}$ \\
\hline 7. Álcool Superior $(\mathrm{mg} / 100 \mathrm{~mL}$ de Álcool Anidro) & 164,19 & $\mathbf{3 6 0 , 0}$ \\
\hline 8. Furfural $(\mathrm{mg} / 100 \mathrm{~mL}$ de Álcool Anidro) & 3,00 & 5,0 \\
\hline 9. Aldeídos em Aldeído Acético (mg/100mL de Álcool Anidro) & 15,19 & 30,0 \\
\hline 10. Ésteres em Acetato de Etila (mg/100mL de Álcool Anidro) & 15,69 & 200,0 \\
\hline 11. Soma dos Componentes Secundários (mg/100mL de Álcool Anidro) & 225,03 & 650,0 \\
\hline 12. Álcool Metílico (mg/100mL de Álcool Anidro) & 6,25 & 20,0 \\
\hline 13. Açúcares Totais (g/L em Sacarose) - Aguardente Simples & $-\mathrm{x}-$ & $\leq 6,0$ \\
\hline 14. Açúcares Totais (g/L em Sacarose) - Aguardente Adoçada & $-\mathrm{x}-$ & $\leq 30,0$ \\
\hline
\end{tabular}

* D.O.I. - Seçẫo 1 - Ediçâo número 124 de 30/06/2005: MAPA, Instruçâo Normativa no 13 de 29/06/2005.

Notas:

1. A presente análise tem valor restrito à amostra recebida no Laboratório.

2. A identificação das amostras é de exclusiva responsabilidade do remetente.

3. Referência bibliográfica do método utilizado: MAPA/DAS/CGAL - Manual de Métodos de Análises de Bebidas e Vinagres (met.

$1,5,10,12,13,16,19,24)$.

4. Método utilizado TC01 e TC02 (Documento do Sistema de Qualidade do LAFQA).

Obs: Luanda - Amostra 9 - Quinta batelada/alambique 1

Conclusão: A amostra analisada atende aos PIQ's para aguardente de mel.

$$
\text { Marrir das Ancreas Candoso }
$$

Maria das Graças Cardoso CRQ $02100835-2^{\mathrm{a}}$ REGIÃO/BH Coordenadora do LAB-UFLA/MG 


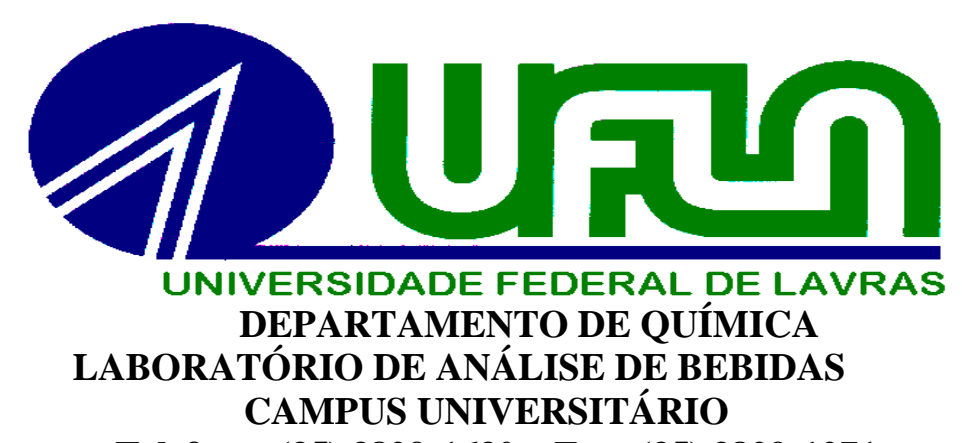

Telefone: (35) 3829-1630 - Fax: (35) 3829-1271

Caixa Postal, 3037 - CEP: 37200-000 - Lavras - Minas Gerais

CERTIFICADO DE ANÁLISE No: 13/2011

Amostra de: Aguardente de Mel, marca: -x-, lote: -x-, tipo: Simples, produzida e/ou engarrafada por: A/C Prof. Dr. Ismael Maciel de Mancilha, endereço: Escola de Engenharia de Lorena - EEL/USP Departamento de Biotecnologia, na cidade e/ou município de: Lorena, no estado de: SP, que deu entrada neste laboratório em:17/2/2011.

\begin{tabular}{|c|c|c|}
\hline Itens Analisados & Resultados & $\begin{array}{c}\text { Limite } \\
\text { Máximo }\end{array}$ \\
\hline 1. Exame Organoléptico & Normal & $-x-$ \\
\hline 2. Densidade Relativa $\left(20 / 20^{\circ} \mathrm{C}\right)$ & 0,94205 & $-\mathrm{x}-$ \\
\hline 3. Cobre $(\mathrm{mg} / \mathrm{L})$ & 2,54 & $\mathbf{5 , 0}$ \\
\hline 4. Extrato Seco a $100^{\circ} \mathrm{C}(\mathrm{g} / \mathrm{L})$ & 0,036 & $-\mathrm{X}-$ \\
\hline 5. Grau Alcoólico Real a $20^{\circ} \mathrm{C}(\% \mathrm{~V} / \mathrm{V})$ & 44,49 & 54,0 \\
\hline 6. Acidez Volátil em Ácido Acético (mg/100mL de Álcool Anidro) & 26,96 & $\mathbf{1 5 0 , 0}$ \\
\hline 7. Álcool Superior $(\mathrm{mg} / 100 \mathrm{~mL}$ de Álcool Anidro) & 196,73 & $\mathbf{3 6 0 , 0}$ \\
\hline 8. Furfural $(\mathrm{mg} / 100 \mathrm{~mL}$ de Álcool Anidro) & 1,74 & 5,0 \\
\hline 9. Aldeídos em Aldeído Acético (mg/100mL de Álcool Anidro) & 20,20 & 30,0 \\
\hline 10. Ésteres em Acetato de Etila (mg/100mL de Álcool Anidro) & 25,48 & 200,0 \\
\hline 11. Soma dos Componentes Secundários (mg/100mL de Álcool Anidro) & 271,11 & 650,0 \\
\hline 12. Álcool Metílico (mg/100mL de Álcool Anidro) & 6,25 & 20,0 \\
\hline 13. Açúcares Totais (g/L em Sacarose) - Aguardente Simples & $-\mathrm{x}-$ & $\leq 6,0$ \\
\hline 14. Açúcares Totais (g/L em Sacarose) - Aguardente Adoçada & $-\mathrm{x}-$ & $\leq 30,0$ \\
\hline
\end{tabular}

* D.O.I. - Seçẫo 1 - Ediçấo número 124 de 30/06/2005: MAPA, Instruçâo Normativa nº 13 de 29/06/2005.

Notas:

1. A presente análise tem valor restrito à amostra recebida no Laboratório.

2. A identificação das amostras é de exclusiva responsabilidade do remetente.

3. Referência bibliográfica do método utilizado: MAPA/DAS/CGAL - Manual de Métodos de Análises de Bebidas e Vinagres (met.

$1,5,10,12,13,16,19,24)$.

4. Método utilizado TC01 e TC02 (Documento do Sistema de Qualidade do LAFQA).

Obs: Luanda - Amostra 10 - Quinta batelada/alambique 2

Conclusão: A amostra analisada atende aos PIQ's para aguardente de mel.

Mavei das Cincuas Candoso

Maria das Graças Cardoso CRQ $02100835-2^{\mathrm{a}}$ REGIÃO/BH Coordenadora do LAB-UFLA/MG 


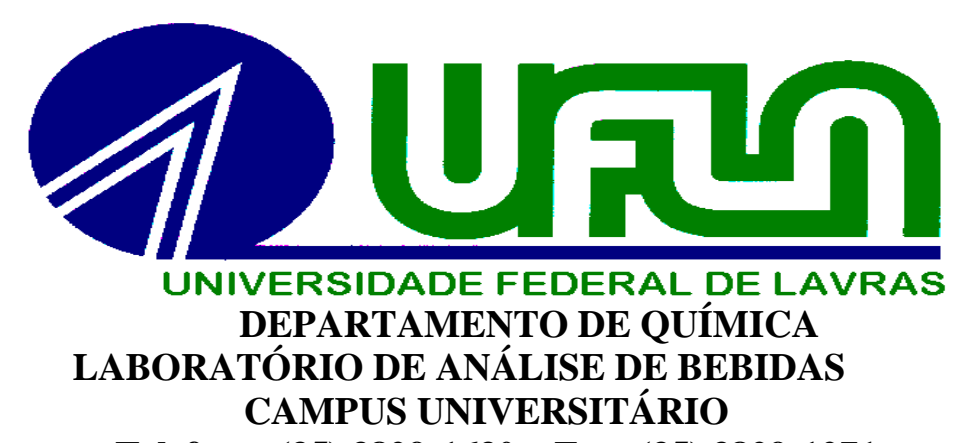

Telefone: (35) 3829-1630 - Fax: (35) 3829-1271

Caixa Postal, 3037 - CEP: 37200-000 - Lavras - Minas Gerais

CERTIFICADO DE ANÁLISE No: 14/2011

Amostra de: Aguardente de Mel, marca: -x-, lote: -x-, tipo: Simples, produzida e/ou engarrafada por: A/C Prof. Dr. Ismael Maciel de Mancilha, endereço: Escola de Engenharia de Lorena - EEL/USP Departamento de Biotecnologia, na cidade e/ou município de: Lorena, no estado de: SP, que deu entrada neste laboratório em:17/2/2011.

\begin{tabular}{|c|c|c|}
\hline Itens Analisados & Resultados & $\begin{array}{c}\text { Limite } \\
\text { Máximo }\end{array}$ \\
\hline 1. Exame Organoléptico & Normal & $-x-$ \\
\hline 2. Densidade Relativa $\left(20 / 20^{\circ} \mathrm{C}\right)$ & 0,94280 & $-\mathrm{x}-$ \\
\hline 3. $\quad$ Cobre $(\mathrm{mg} / \mathrm{L})$ & 2,49 & $\mathbf{5 , 0}$ \\
\hline 4. Extrato Seco a $100^{\circ} \mathrm{C}(\mathrm{g} / \mathrm{L})$ & 0,060 & $-\mathrm{X}-$ \\
\hline 5. Grau Alcoólico Real a $20^{\circ} \mathrm{C}(\% \mathrm{~V} / \mathrm{V})$ & 44,07 & 54,0 \\
\hline 6. Acidez Volátil em Ácido Acético (mg/100mL de Álcool Anidro) & 30,62 & $\mathbf{1 5 0 , 0}$ \\
\hline 7. Álcool Superior (mg/100mL de Álcool Anidro) & 177,82 & 360,0 \\
\hline 8. Furfural (mg/100mL de Álcool Anidro) & 1,76 & 5,0 \\
\hline 9. Aldeídos em Aldeído Acético (mg/100mL de Álcool Anidro) & 20,01 & 30,0 \\
\hline 10. Ésteres em Acetato de Etila (mg/100mL de Álcool Anidro) & 25,73 & 200,0 \\
\hline 11. Soma dos Componentes Secundários (mg/100mL de Álcool Anidro) & 255,94 & 650,0 \\
\hline 12. Álcool Metílico (mg/100mL de Álcool Anidro) & 5,82 & 20,0 \\
\hline 13. Açúcares Totais (g/L em Sacarose) - Aguardente Simples & $-\mathrm{x}-$ & $\leq 6,0$ \\
\hline 14. Açúcares Totais (g/L em Sacarose) - Aguardente Adoçada & $-\mathrm{x}-$ & $\leq \mathbf{3 0 , 0}$ \\
\hline
\end{tabular}

* D.O.I. - Seçẫo 1 - Ediçấo número 124 de 30/06/2005: MAPA, Instruçâo Normativa nº 13 de 29/06/2005.

Notas:

1. A presente análise tem valor restrito à amostra recebida no Laboratório.

2. A identificação das amostras é de exclusiva responsabilidade do remetente.

3. Referência bibliográfica do método utilizado: MAPA/DAS/CGAL - Manual de Métodos de Análises de Bebidas e Vinagres (met.

$1,5,10,12,13,16,19,24)$.

4. Método utilizado TC01 e TC02 (Documento do Sistema de Qualidade do LAFQA).

Obs: Luanda - Amostra 11 - Tempo zero

Conclusão: A amostra analisada atende aos PIQ's para aguardente de mel.

Marvei das A reveas Oudoso

Maria das Graças Cardoso

CRQ $02100835-2^{\mathrm{a}}$ REGIÃO/BH

Coordenadora do LAB-UFLA/MG 


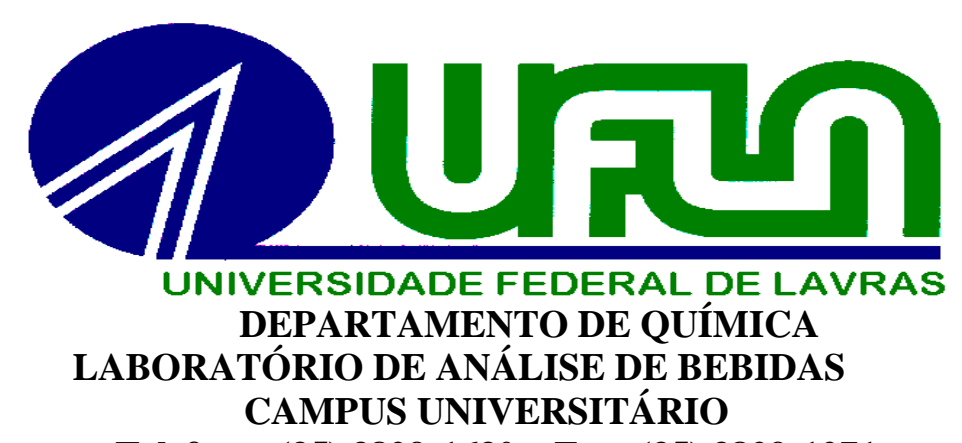

Telefone: (35) 3829-1630 - Fax: (35) 3829-1271

Caixa Postal, 3037 - CEP: 37200-000 - Lavras - Minas Gerais

CERTIFICADO DE ANÁLISE No: 15/2011

Amostra de: Aguardente de Mel, marca: -x-, lote: -x-, tipo: Simples, produzida e/ou engarrafada por: A/C Prof. Dr. Ismael Maciel de Mancilha, endereço: Escola de Engenharia de Lorena - EEL/USP Departamento de Biotecnologia, na cidade e/ou município de: Lorena, no estado de: SP, que deu entrada neste laboratório em:17/2/2011.

\begin{tabular}{|c|c|c|}
\hline Itens Analisados & Resultados & $\begin{array}{c}\text { Limite } \\
\text { Máximo }\end{array}$ \\
\hline 1. Exame Organoléptico & Normal & $-x-$ \\
\hline 2. Densidade Relativa $\left(20 / 20^{\circ} \mathrm{C}\right)$ & 0,94367 & $-\mathrm{x}-$ \\
\hline 3. $\quad$ Cobre $(\mathrm{mg} / \mathrm{L})$ & 1,11 & $\mathbf{5 , 0}$ \\
\hline 4. Extrato Seco a $100^{\circ} \mathrm{C}(\mathrm{g} / \mathrm{L})$ & 0,080 & $-\mathrm{X}-$ \\
\hline 5. Grau Alcoólico Real a $20^{\circ} \mathrm{C}(\% \mathrm{~V} / \mathrm{V})$ & 43,59 & 54,0 \\
\hline 6. Acidez Volátil em Ácido Acético (mg/100mL de Álcool Anidro) & 44,71 & $\mathbf{1 5 0 , 0}$ \\
\hline 7. Álcool Superior $(\mathrm{mg} / 100 \mathrm{~mL}$ de Álcool Anidro) & 173,81 & $\mathbf{3 6 0 , 0}$ \\
\hline 8. Furfural $(\mathrm{mg} / 100 \mathrm{~mL}$ de Álcool Anidro) & 1,71 & 5,0 \\
\hline 9. Aldeídos em Aldeído Acético (mg/100mL de Álcool Anidro) & 19,89 & 30,0 \\
\hline 10. Ésteres em Acetato de Etila (mg/100mL de Álcool Anidro) & 27,01 & 200,0 \\
\hline 11. Soma dos Componentes Secundários (mg/100mL de Álcool Anidro) & 267,13 & 650,0 \\
\hline 12. Álcool Metílico (mg/100mL de Álcool Anidro) & 6,12 & 20,0 \\
\hline 13. Açúcares Totais (g/L em Sacarose) - Aguardente Simples & $-\mathrm{X}-$ & $\leq 6,0$ \\
\hline 14. Açúcares Totais (g/L em Sacarose) - Aguardente Adoçada & $-\mathrm{x}-$ & $\leq 30,0$ \\
\hline
\end{tabular}

* D.O.I. - Seçẫo 1 - Ediçấo número 124 de 30/06/2005: MAPA, Instruçâo Normativa nº 13 de 29/06/2005.

Notas:

1. A presente análise tem valor restrito à amostra recebida no Laboratório.

2. A identificação das amostras é de exclusiva responsabilidade do remetente.

3. Referência bibliográfica do método utilizado: MAPA/DAS/CGAL - Manual de Métodos de Análises de Bebidas e Vinagres (met.

$1,5,10,12,13,16,19,24)$.

4. Método utilizado TC01 e TC02 (Documento do Sistema de Qualidade do LAFQA).

Obs: Luanda - Amostra $12-30$ dias

Conclusão: A amostra analisada atende aos PIQ’s para aguardente de mel. 


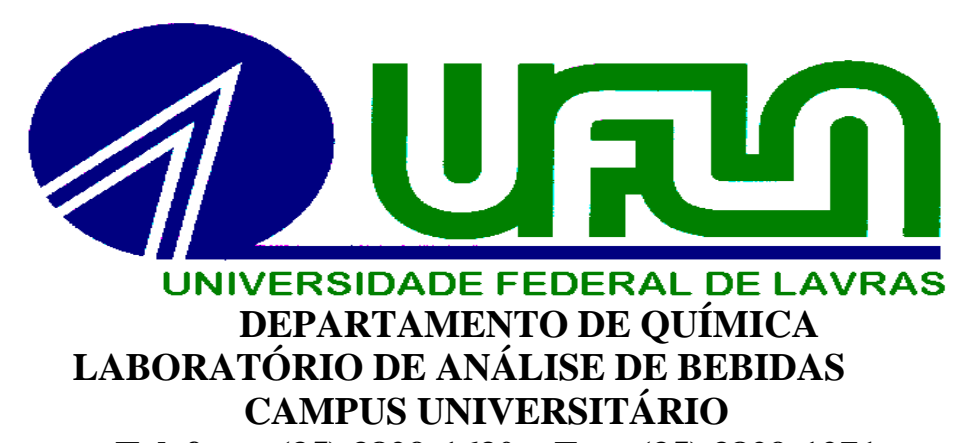

Telefone: (35) 3829-1630 - Fax: (35) 3829-1271

Caixa Postal, 3037 - CEP: 37200-000 - Lavras - Minas Gerais

CERTIFICADO DE ANÁLISE No: 16/2011

Amostra de: Aguardente de Mel, marca: -x-, lote: -x-, tipo: Simples, produzida e/ou engarrafada por: A/C Prof. Dr. Ismael Maciel de Mancilha, endereço: Escola de Engenharia de Lorena - EEL/USP Departamento de Biotecnologia, na cidade e/ou município de: Lorena, no estado de: SP, que deu entrada neste laboratório em:17/2/2011.

\begin{tabular}{|c|c|c|}
\hline Itens Analisados & Resultados & $\begin{array}{c}\text { Limite } \\
\text { Máximo }\end{array}$ \\
\hline 1. Exame Organoléptico & Normal & $-x-$ \\
\hline 2. Densidade Relativa $\left(20 / 20^{\circ} \mathrm{C}\right)$ & 0,94347 & $-\mathrm{x}-$ \\
\hline 3. $\quad$ Cobre $(\mathrm{mg} / \mathrm{L})$ & 1,05 & $\mathbf{5 , 0}$ \\
\hline 4. Extrato Seco a $100^{\circ} \mathrm{C}(\mathrm{g} / \mathrm{L})$ & 0,104 & $-\mathrm{X}-$ \\
\hline 5. Grau Alcoólico Real a $20^{\circ} \mathrm{C}(\% \mathrm{~V} / \mathrm{V})$ & 43,69 & 54,0 \\
\hline 6. Acidez Volátil em Ácido Acético (mg/100mL de Álcool Anidro) & 48,04 & $\mathbf{1 5 0 , 0}$ \\
\hline 7. Álcool Superior (mg/100mL de Álcool Anidro) & 201,59 & 360,0 \\
\hline 8. Furfural (mg/100mL de Álcool Anidro) & 2,12 & 5,0 \\
\hline 9. Aldeídos em Aldeído Acético (mg/100mL de Álcool Anidro) & 20,73 & 30,0 \\
\hline 10. Ésteres em Acetato de Etila (mg/100mL de Álcool Anidro) & 27,95 & 200,0 \\
\hline 11. Soma dos Componentes Secundários (mg/100mL de Álcool Anidro) & 300,43 & 650,0 \\
\hline 12. Álcool Metílico (mg/100mL de Álcool Anidro) & 6,11 & 20,0 \\
\hline 13. Açúcares Totais (g/L em Sacarose) - Aguardente Simples & $-\mathrm{X}-$ & $\leq 6,0$ \\
\hline 14. Açúcares Totais (g/L em Sacarose) - Aguardente Adoçada & $-\mathrm{x}-$ & $\leq \mathbf{3 0 , 0}$ \\
\hline
\end{tabular}

* D.O.I. - Seçẫo 1 - Ediçấo número 124 de 30/06/2005: MAPA, Instruçâo Normativa nº 13 de 29/06/2005.

Notas:

1. A presente análise tem valor restrito à amostra recebida no Laboratório.

2. A identificação das amostras é de exclusiva responsabilidade do remetente.

3. Referência bibliográfica do método utilizado: MAPA/DAS/CGAL - Manual de Métodos de Análises de Bebidas e Vinagres (met.

$1,5,10,12,13,16,19,24)$.

4. Método utilizado TC01 e TC02 (Documento do Sistema de Qualidade do LAFQA).

Obs: Luanda - Amostra 13 - 60 dias

Conclusão: A amostra analisada atende aos PIQ’s para aguardente de mel. 


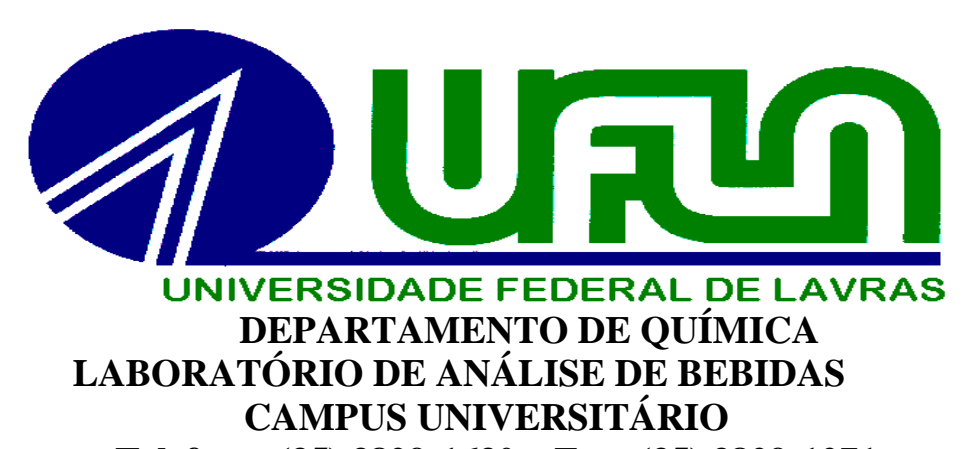

Telefone: (35) 3829-1630 - Fax: (35) 3829-1271

Caixa Postal, 3037 - CEP: 37200-000 - Lavras - Minas Gerais

CERTIFICADO DE ANÁLISE No: 28/2011

Amostra de: Aguardente de Mel, marca: -x-, lote: -x-, tipo: Simples, produzida e/ou engarrafada por: A/C Prof. Dr. Ismael Maciel de Mancilha, endereço: Escola de Engenharia de Lorena - EEL/USP Departamento de Biotecnologia, na cidade e/ou município de: Lorena, no estado de: SP, que deu entrada neste laboratório em: 5/4/2011.

\begin{tabular}{|c|c|c|}
\hline Itens Analisados & Resultados & $\begin{array}{c}\text { Limite } \\
\text { Máximo }\end{array}$ \\
\hline 1. Exame Organoléptico & Normal & $-x-$ \\
\hline 2. Densidade Relativa $\left(20 / 20^{\circ} \mathrm{C}\right)$ & 0,94310 & $-\mathrm{x}-$ \\
\hline 3. $\quad$ Cobre $(\mathrm{mg} / \mathrm{L})$ & 1,36 & $\mathbf{5 , 0}$ \\
\hline 4. Extrato Seco a $100^{\circ} \mathrm{C}(\mathrm{g} / \mathrm{L})$ & 0,112 & $-\mathrm{X}-$ \\
\hline 5. Grau Alcoólico Real a $20^{\circ} \mathrm{C}(\% \mathrm{~V} / \mathrm{V})$ & 43,91 & 54,0 \\
\hline 6. Acidez Volátil em Ácido Acético (mg/100mL de Álcool Anidro) & 47,30 & $\mathbf{1 5 0 , 0}$ \\
\hline 7. Álcool Superior $(\mathrm{mg} / 100 \mathrm{~mL}$ de Álcool Anidro) & 180,25 & $\mathbf{3 6 0 , 0}$ \\
\hline 8. Furfural $(\mathrm{mg} / 100 \mathrm{~mL}$ de Álcool Anidro) & 2,14 & 5,0 \\
\hline 9. Aldeídos em Aldeído Acético (mg/100mL de Álcool Anidro) & 20,37 & 30,0 \\
\hline 10. Ésteres em Acetato de Etila (mg/100mL de Álcool Anidro) & 24,10 & 200,0 \\
\hline 11. Soma dos Componentes Secundários (mg/100mL de Álcool Anidro) & 274,16 & 650,0 \\
\hline 12. Álcool Metílico (mg/100mL de Álcool Anidro) & 13,22 & 20,0 \\
\hline 13. Açúcares Totais (g/L em Sacarose) - Aguardente Simples & $-\mathrm{X}-$ & $\leq 6,0$ \\
\hline 14. Açúcares Totais (g/L em Sacarose) - Aguardente Adoçada & $-\mathrm{x}-$ & $\leq 30,0$ \\
\hline
\end{tabular}

* D.O.I. - Seçẫo 1 - Ediçấo número 124 de 30/06/2005: MAPA, Instruçâo Normativa nº 13 de 29/06/2005.

Notas:

1. A presente análise tem valor restrito à amostra recebida no Laboratório.

2. A identificação das amostras é de exclusiva responsabilidade do remetente.

3. Referência bibliográfica do método utilizado: MAPA/DAS/CGAL - Manual de Métodos de Análises de Bebidas e Vinagres (met.

$1,5,10,12,13,16,19,24)$.

4. Método utilizado TC01 e TC02 (Documento do Sistema de Qualidade do LAFQA).

Obs: Luanda - Amostra 14 - 90 dias

Conclusão: A amostra analisada atende aos PIQ's para aguardente de mel.

Mavei das Crevean Cundoso

Lavras, 8 de Abril de 2011

Maria das Graças Cardoso CRQ $02100835-2^{\mathrm{a}}$ REGIÃO/BH Coordenadora do LAB-UFLA/MG 


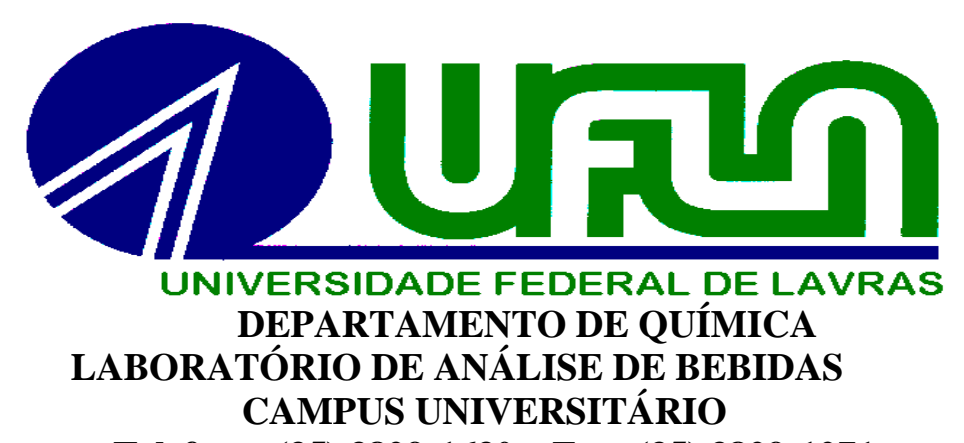

Telefone: (35) 3829-1630 - Fax: (35) 3829-1271

Caixa Postal, 3037 - CEP: 37200-000 - Lavras - Minas Gerais

CERTIFICADO DE ANÁLISE No: 29/2011

Amostra de: Aguardente de Mel, marca: -x-, lote: -x-, tipo: Simples, produzida e/ou engarrafada por: A/C Prof. Dr. Ismael Maciel de Mancilha, endereço: Escola de Engenharia de Lorena - EEL/USP Departamento de Biotecnologia, na cidade e/ou município de: Lorena, no estado de: SP, que deu entrada neste laboratório em: 5/4/2011.

\begin{tabular}{|c|c|c|}
\hline Itens Analisados & Resultados & $\begin{array}{c}\text { Limite } \\
\text { Máximo }\end{array}$ \\
\hline 1. Exame Organoléptico & Normal & $-x-$ \\
\hline 2. Densidade Relativa $\left(20 / 20^{\circ} \mathrm{C}\right)$ & 0,94310 & $-\mathrm{x}-$ \\
\hline 3. $\quad$ Cobre $(\mathrm{mg} / \mathrm{L})$ & 1,39 & $\mathbf{5 , 0}$ \\
\hline 4. Extrato Seco a $100^{\circ} \mathrm{C}(\mathrm{g} / \mathrm{L})$ & 0,116 & $-\mathrm{X}-$ \\
\hline 5. Grau Alcoólico Real a $20^{\circ} \mathrm{C}(\% \mathrm{~V} / \mathrm{V})$ & 43,91 & 54,0 \\
\hline 6. Acidez Volátil em Ácido Acético (mg/100mL de Álcool Anidro) & 50,67 & $\mathbf{1 5 0 , 0}$ \\
\hline 7. Álcool Superior $(\mathrm{mg} / 100 \mathrm{~mL}$ de Álcool Anidro) & 172,28 & $\mathbf{3 6 0 , 0}$ \\
\hline 8. Furfural $(\mathrm{mg} / 100 \mathrm{~mL}$ de Álcool Anidro) & 2,23 & 5,0 \\
\hline 9. Aldeídos em Aldeído Acético (mg/100mL de Álcool Anidro) & 20,62 & 30,0 \\
\hline 10. Ésteres em Acetato de Etila (mg/100mL de Álcool Anidro) & 26,10 & 200,0 \\
\hline 11. Soma dos Componentes Secundários (mg/100mL de Álcool Anidro) & 271,90 & 650,0 \\
\hline 12. Álcool Metílico (mg/100mL de Álcool Anidro) & 9,12 & 20,0 \\
\hline 13. Açúcares Totais (g/L em Sacarose) - Aguardente Simples & $-\mathrm{X}-$ & $\leq 6,0$ \\
\hline 14. Açúcares Totais (g/L em Sacarose) - Aguardente Adoçada & $-\mathrm{x}-$ & $\leq 30,0$ \\
\hline
\end{tabular}

* D.O.I. - Seçẫo 1 - Ediçấo número 124 de 30/06/2005: MAPA, Instruçâo Normativa nº 13 de 29/06/2005.

Notas:

1. A presente análise tem valor restrito à amostra recebida no Laboratório.

2. A identificação das amostras é de exclusiva responsabilidade do remetente.

3. Referência bibliográfica do método utilizado: MAPA/DAS/CGAL - Manual de Métodos de Análises de Bebidas e Vinagres (met.

$1,5,10,12,13,16,19,24)$.

4. Método utilizado TC01 e TC02 (Documento do Sistema de Qualidade do LAFQA).

Obs: Luanda - Amostra 15 - 120 dias

Conclusão: A amostra analisada atende aos PIQ's para aguardente de mel.

Marrei das Creveas Candoso

Lavras, 8 de Abril de 2011

Maria das Graças Cardoso

CRQ $02100835-2^{\mathrm{a}}$ REGIÃO/BH

Coordenadora do LAB-UFLA/MG 


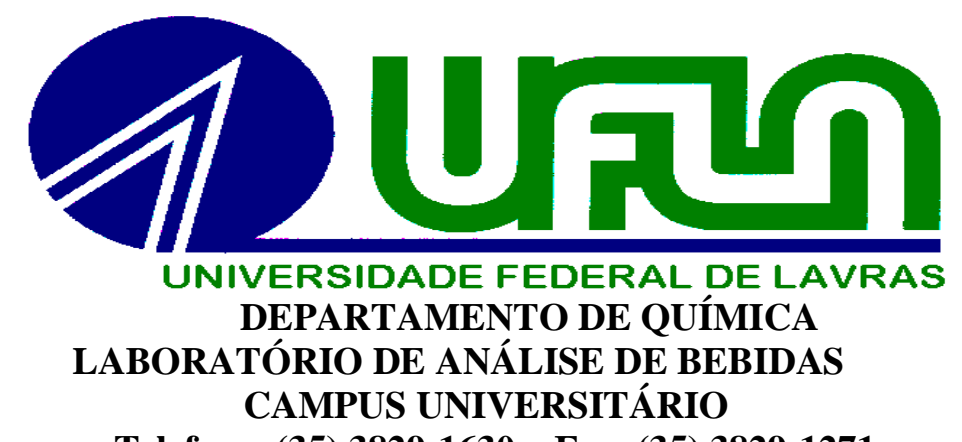

Telefone: (35) 3829-1630 - Fax: (35) 3829-1271

Caixa Postal, 3037 - CEP: 37200-000 - Lavras - Minas Gerais

CERTIFICADO DE ANÁLISE No: $\mathbf{6 4 / 2 0 1 1}$

Amostra de: Aguardente de Mel, marca: -x-, lote: -x-, tipo: Simples, produzida e/ou engarrafada por: A/C Prof. Dr. Ismael Maciel de Mancilha, endereço: Escola de Engenharia de Lorena - EEL/USP Departamento de Biotecnologia, na cidade e/ou município de: Lorena, no estado de: SP, que deu entrada neste laboratório em: 1/6/2011.

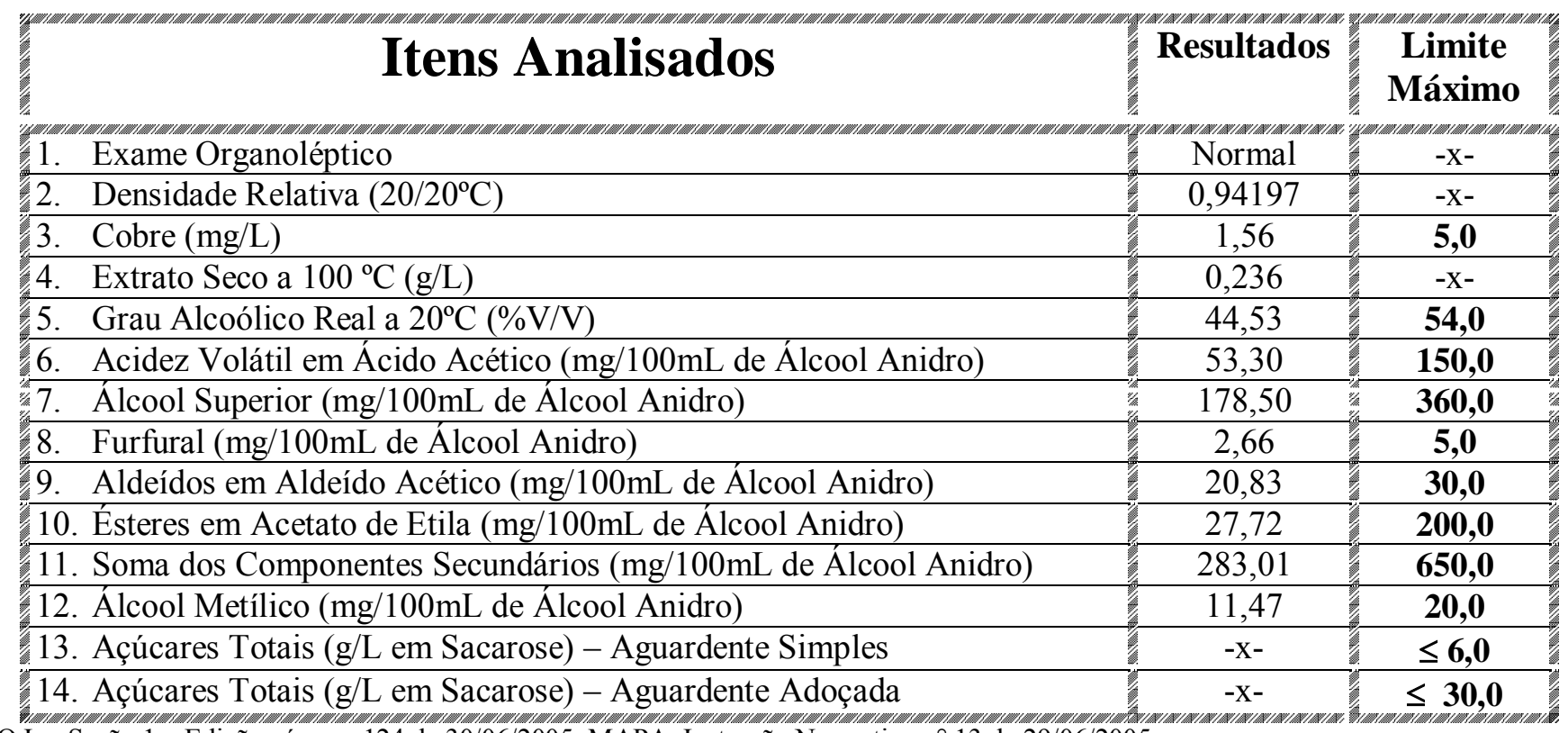

* D.O.I. - Seção 1 - Edição número 124 de 30/06/2005: MAPA, Instrução Normativa n 13 de 29/06/2005.

Notas:

1. A presente análise tem valor restrito à amostra recebida no Laboratório.

2. A identificação das amostras é de exclusiva responsabilidade do remetente.

3. Referência bibliográfica do método utilizado: MAPA/DAS/CGAL - Manual de Métodos de Análises de Bebidas e Vinagres (met.

$1,5,10,12,13,16,19,24)$.

4. Método utilizado TC01 e TC02 (Documento do Sistema de Qualidade do LAFQA).

Obs: Luanda - Amostra 16 - 150 dias

Conclusão: A amostra analisada atende aos PIQ's para aguardente de mel.

Marrei das Creveos Cudoso

Lavras, 8 de Junho de 2011

Maria das Graças Cardoso

CRQ $02100835-2^{\mathrm{a}}$ REGIÃO/BH

Coordenadora do LAB-UFLA/MG 


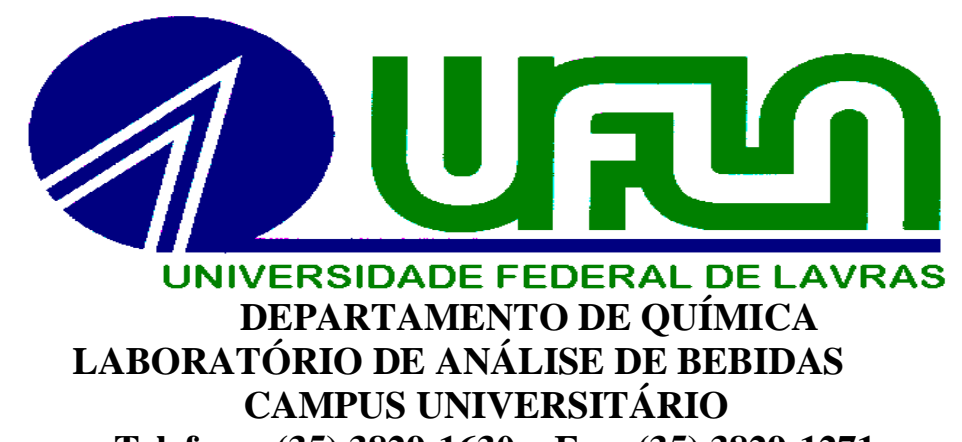

Telefone: (35) 3829-1630 - Fax: (35) 3829-1271

Caixa Postal, 3037 - CEP: 37200-000 - Lavras - Minas Gerais

CERTIFICADO DE ANÁLISE No: $\mathbf{6 5 / 2 0 1 1}$

Amostra de: Aguardente de Mel, marca: -x-, lote: -x-, tipo: Simples, produzida e/ou engarrafada por: A/C Prof. Dr. Ismael Maciel de Mancilha, endereço: Escola de Engenharia de Lorena - EEL/USP Departamento de Biotecnologia, na cidade e/ou município de: Lorena, no estado de: SP, que deu entrada neste laboratório em: 1/6/2011.

\begin{tabular}{|c|c|c|}
\hline Itens Analisados & Resultados & $\begin{array}{c}\text { Limite } \\
\text { Máximo }\end{array}$ \\
\hline 1. Exame Organoléptico & Normal & $-x-$ \\
\hline 2. Densidade Relativa $\left(20 / 20^{\circ} \mathrm{C}\right)$ & 0,94182 & $-\mathrm{x}-$ \\
\hline 3. Cobre $(\mathrm{mg} / \mathrm{L})$ & 1,76 & $\mathbf{5 , 0}$ \\
\hline 4. Extrato Seco a $100^{\circ} \mathrm{C}(\mathrm{g} / \mathrm{L})$ & 0,236 & $-\mathrm{x}-$ \\
\hline 5. Grau Alcoólico Real a $20^{\circ} \mathrm{C}(\% \mathrm{~V} / \mathrm{V})$ & 44,63 & 54,0 \\
\hline 6. Acidez Volátil em Ácido Acético (mg/100mL de Álcool Anidro) & 56,51 & 150,0 \\
\hline 7. Álcool Superior (mg/100mL de Álcool Anidro) & 179,86 & $\mathbf{3 6 0 , 0}$ \\
\hline 8. Furfural (mg/100mL de Álcool Anidro) & 2,70 & $\mathbf{5 , 0}$ \\
\hline 9. Aldeídos em Aldeído Acético (mg/100mL de Álcool Anidro) & 21,28 & $\mathbf{3 0 , 0}$ \\
\hline 10. Ésteres em Acetato de Etila (mg/100mL de Álcool Anidro) & 27,66 & 200,0 \\
\hline 11. Soma dos Componentes Secundários ( $\mathrm{mg} / 100 \mathrm{~mL}$ de Álcool Anidro) & 288,01 & 650,0 \\
\hline 12. Álcool Metílico (mg/100mL de Álcool Anidro) & 10,07 & 20,0 \\
\hline 13. Açúcares Totais ( $\mathrm{g} / \mathrm{L}$ em Sacarose) - Aguardente Simples & $-\mathrm{x}-$ & $\leq 6,0$ \\
\hline 14. Açúcares Totais (g/L em Sacarose) - Aguardente Adoçada & $-\mathrm{-x}-$ & $\leq \mathbf{3 0 , 0}$ \\
\hline
\end{tabular}

* D.O.I. - Seção 1 - Edição número 124 de 30/06/2005: MAPA, Instrução Normativa nº 13 de 29/06/2005.

Notas:

1. A presente análise tem valor restrito à amostra recebida no Laboratório.

2. A identificação das amostras é de exclusiva responsabilidade do remetente.

3. Referência bibliográfica do método utilizado: MAPA/DAS/CGAL - Manual de Métodos de Análises de Bebidas e Vinagres (met.

$1,5,10,12,13,16,19,24)$.

4. Método utilizado TC01 e TC02 (Documento do Sistema de Qualidade do LAFQA).

Obs: Luanda - Amostra 17 - 180 dias

Conclusão: A amostra analisada atende aos PIQ’s para aguardente de mel.

Mavie das Cincuas Candoso

Maria das Graças Cardoso

CRQ $02100835-2^{\mathrm{a}}$ REGIÃO/BH

Coordenadora do LAB-UFLA/MG 